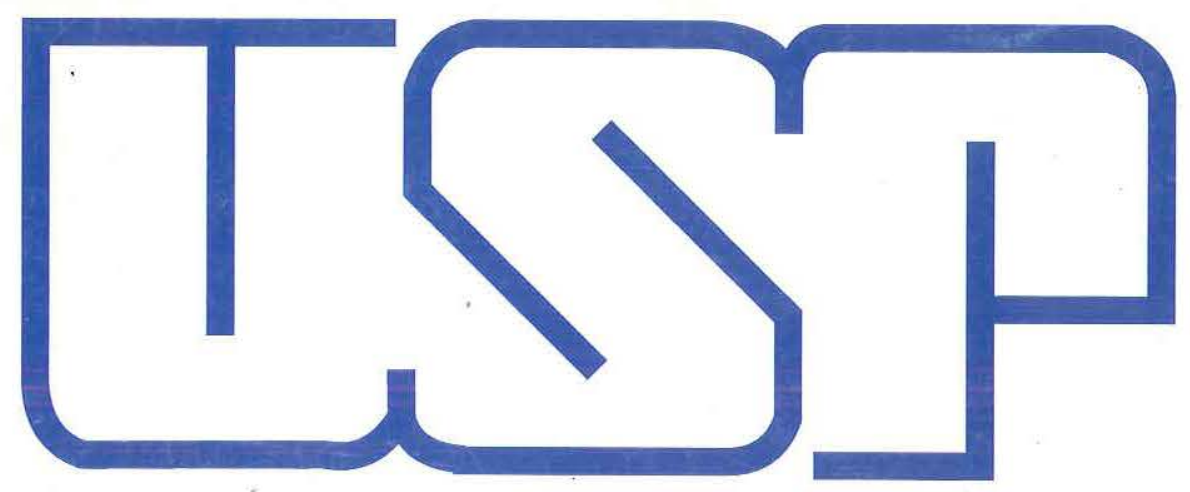

Estudo da Resistência Mecânica do Ligamento Cruzado Anterior de Ratos Submetidos à Imobilização

Autora: Cristiane Spolador Pátaro Domingos Orientador: Prof. Dr. Cleber Antonio J. Paccola

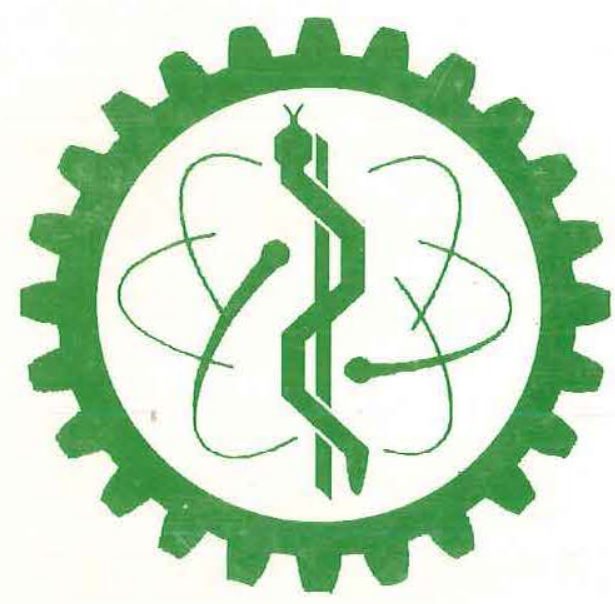

B I O E N G EN H AR I A

USP

Curso de Pós-Graduação Interunidades Bioengenharia

Escola de Engenharia de São Carlos

Faculdade de Medicina de Ribeirão Preto

. Instituto de Química de São Carlos 


\section{ESTUDO DA RESISTÊNCIA MECÂNICA DO LIGAMENTO CRUZADO ANTERIOR DE RATOS SUBMETIDOS À IMOBILIZAÇÃO}

\section{Cristiane Spolador Pátaro Domingos}

Dissertação de Mestrado apresentada à Faculdade de Medicina de Ribeirão Preto e Escola de Engenharia de São Carlos da Universidade de São Paulo.

Área Interunidades de Bioengenharia

Orientador: Prof. Dr. Cleber Antonio Jansen Paccola

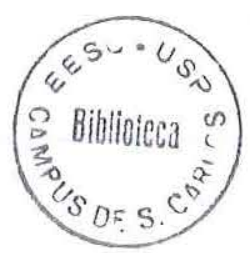

RIBEIRÃO PRETO - SÃO CARLOS

1998 


$$
\frac{\text { Cinem IFSE FFS }}{\text { Guth } \frac{1919}{\text { Tombo T0287/98 }}}
$$

Domingos, Cristiane Spolador Pátaro

Estudo da resistência do ligamento cruzado anterior de ratos submetidos a imobilização / Cristiane Spolador Pátaro Domingos. Ribeirão Preto, 1998.

Dissertação de Mestrado - Bioengenharia - Interunidades: Escola de Engenharia de São Carlos e Faculdade de Medicina de Ribeirão Preto- Universidade de São Paulo, 1998.

Orientador: Paccola, Cleber A. J.

1.ligamento cruzado anterior 2.imobilização 3.resistência mecânica 4.ensaio mecânico de tração 5.joelho 6.rato 


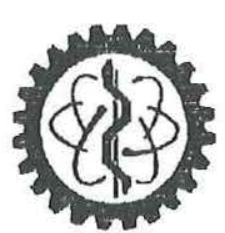

BIOENGENHARIA USP

\section{Universidade de São Paulo}

Curso de Pós-Giraduação Interunidades Bioengenharia

Escola de Engenharia de São Carlos

Faculdade de Medicina de Ribeirão Prêto

Instituto de Química de São Carlos

Av. Dr. Carlos Botclho, 1465 - C.P. 359 - 1356()-970 - São Carlos - SP - BRASIL

Tcl. (016) 273-9585 Fax: (016) 273-9586 Email: biocng@sc.usp.br

TERMO DE .JULGAMENTO DE DEFESA DE DISSERTAÇAO DE MESTRADO

Aos catorze dias do mês de agosto de mil novecentos e noventa e oito, às catorze horas, no Laboratório de Bioengenharia da Faculdade de Medicina de Ribeirão Preto da Universidade de São Paulo, perante a Comissão Julgadora abaixo assinada, integrada pelos Professores Dr. Cleber Antonio Jansen Paccola - FMRP-USP; Prof. Dr. Celso Hermínio Ferraz Picado-FMRP-USP; Prof. Dr. Edgard Eduard Engel - HCFMRP-USP, iniciou-se a defesa pública da Dissertação de Mestrado de Cristiane Spolador Pátaro Domingos intitulada "Estudo da Resistência Mecânica do Ligamento Cruzado Anterior de Ratos Submetidos à Imobilização", como parte dos requisitos para obtenção do título de MESTRE EM BIOENGENHARIA. Concluída a argüição procedeu-se ao julgamento na forma regularmentar, tendo a Comissão Julgadora atribuído ao candidato:

Prof. Dr. Cleber Antonio Jansen Paccola

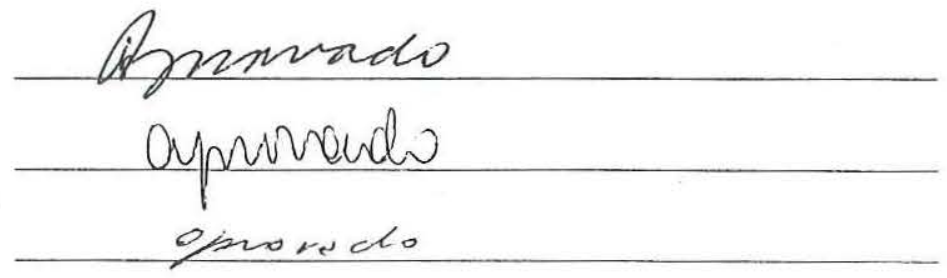

Prof. Dr. Celso Herminio Ferraz Picado

Prof. Dr. Edgard Eduard Engel

oinorecto

O candidato foi considerado habilitado à obtenção do título de MESTRE. Para constar, é lavrado o presente Termo, que segue assinado pela Comissão Julgadora respectiva.

Ribeirão Preto, 14 de agosto de 1998.

Presidente

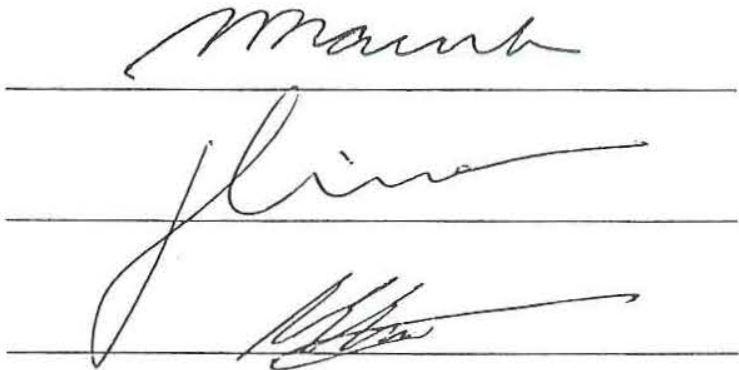


"Nunca the dão um desejo sem tamberm the darem o poder de realisá-lo.

Você pode ter de Irabalhar por ele porém."

(Richard $\mathscr{B}$ ach) 
"Ainda que cu fale a linguagem dos homens e dos anjos, Sinda que eu tenha o Dom de profetirar; $E$ conheca todos os mistérios da naturera, Se nĩa houver amor, eu nada serei."

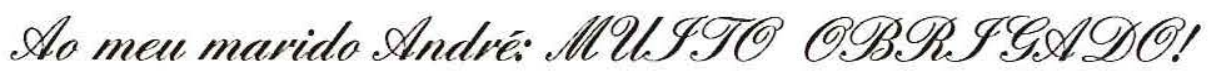

Ho mu filho HOXIO YSTOR

Que cu tenha conseguido compensar os momentos de ausência. 
Los meus pais: OSYYLDDO e VERQA Que sempre me incentivaram e me deram condiçóes para que eu chegasse até aqui.

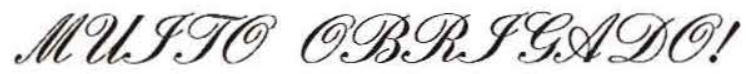




\section{A G R A D E C I M E N T O S}

Não posso deixar de registrar a minha gratidão a todos que com muito carinho e atenção se esforçaram para me auxiliar e superar as etapas que surgiram no desenvolvimento desta dissertação. Muito Obrigado!

Ao Prof. Dr. Cléber Antônio Jansen Paccola, orientador de notável saber científico, o qual muito me incentivou no decorrer deste trabalho, o meu Muito Obrigado em especial.

目 À Fapesp, por ter acreditado no meu projeto, e principalmente pela concessão de Bolsa de Mestrado, indispensável na realização deste trabalho;

Ao Engenheiro Carlos Alberto Moro, pelo auxílio, sugestões, compreensão e respaldo técnico durante a confeç̧ão deste trabalho, bem como o apoio nos momentos dificeis;

Ao Engenheiro Doutor Antônio Carlos Shimano, pela orientação e conselhos;

Aos Técnicos do Laboratório de Bioengenharia, Luiz Henrique Alves Pereira, pelo apreço e dedicação, mas com especial gratidão ao Francisco Carlos Mazzocato, cuja colaboração extrapolou o fazer profissional, participando como amigo e confidente nas horas mais dificeis e principalmente vibrando nas etapas vitoriosas; 
Ao Prof. Dr. J. B. Portugal Paulin, chefe do Laboratório de Bioengenharia, onde foram realizados os ensaios mecânicos, e pelas sugestões e incentivo ao desenvolvimento deste projeto;

Aos funcionários da Oficina Mecânica de Precisão da Prefeitura do Campus Administrativo de Ribeirão Preto - USP, especialmente na pessoa do Otávio Terra Filho, profissional dedicado que confeccionou todos os dispositivos utilizados na elaboração deste trabalho;

Ao Biotério Central da Faculdade de Medicina de Ribeirão Preto - USP, pelo fornecimento dos animais utilizados neste trabalho;

Ao amigo Adriano de Jesus Holanda, pela ajuda inestimável na área de informática;

Ao Prof. Dr. Luiz de Souza, pela orientação da análise estatística dos resultados;

As secretárias Maria de Fátima Feitosa de Lima e Rosa Pereira Brittes Alves, da pós-graduação da Ortopedia, que me atenderam sempre com carinho especial e muita paciência. 


\section{SUMÁRIO}

1. INTRODUÇÃO...........................................................................................................

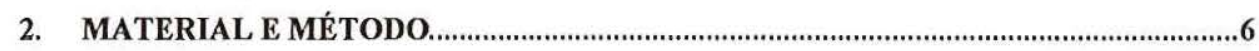

2.1 ANIMAL UTILIZADO:

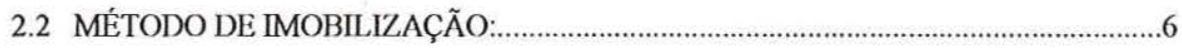

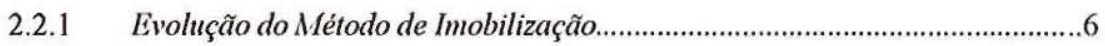

2.3 TÉCNICA UTILIZADA PARA SACRIFICAR OS ANIMAIS:.....................................11

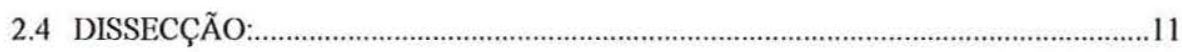

2.5 MÉTODO DE CONSERVAÇÃO DO ESPÉCIME:..........................................................12

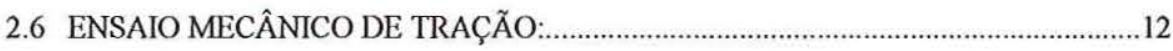

2.6.1 Evolução da Metodologia Utilizada Para o Ensaio Mecânico de Tração.......13

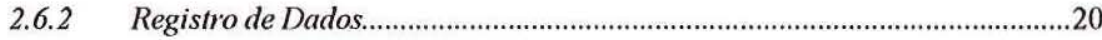

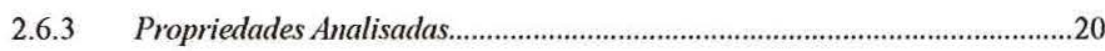

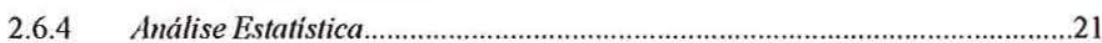

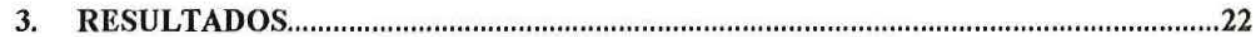

3.1 RESULTADOS DAS PROPRIEDADES ANALISADAS PARA O GRUPO DE

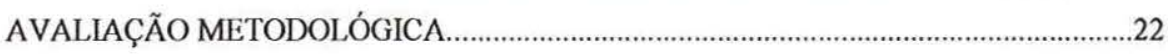

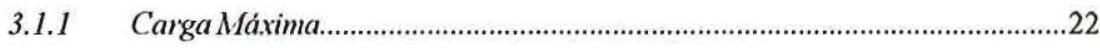

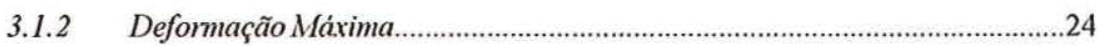

3.1.3 Energia Absorvida Pelo Ligamento Até o Momento da Ruptura.....................26

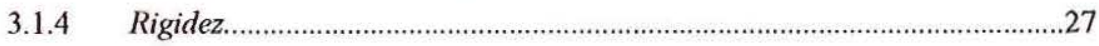

3.2 RESULTADOS DAS PROPRIEDADES ANALISADAS NO GRUPO

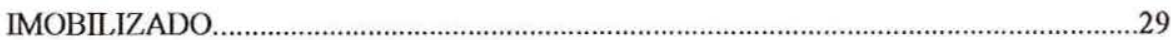

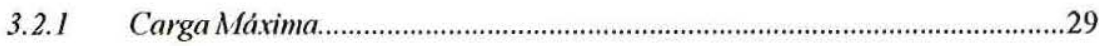

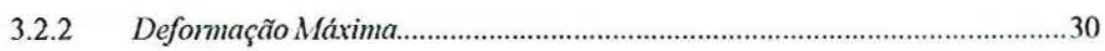

3.2.3 Energia Absonvida Pelo Ligamento Até o Momento da Ruptura.....................32

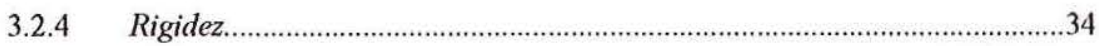

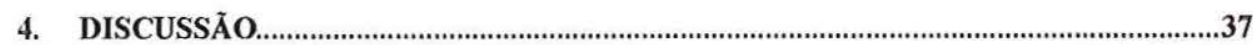

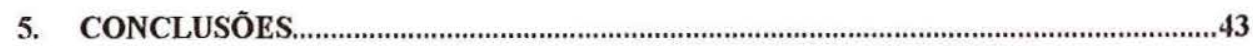

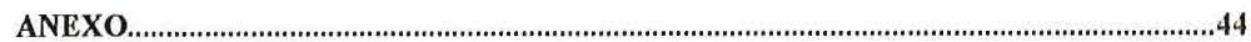

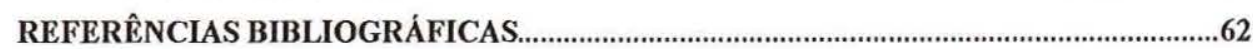

APÊNDICE 1

APÊNDICE 2 


\section{LISTA DE FIGURAS}

FIGURA 1-Proteção com tira de flanela, para proteger a região do tornozelo contra o gesso

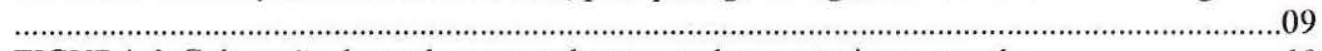

FIGURA 2-Colocação da atadura gessada no membro posterior esquerdo...............................10

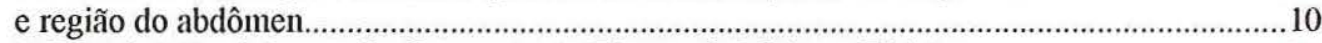

FIGURA 3-Espécime após dissecação (a-Fêmur , b-LCA, c- Tíbia).........................................11

FIGURA 4-Vista geral da máquina universal de ensaio do Laboratório de Bioengenharia da

Faculdade de Medicina de Ribeirão Preto/USP...................................................................12

FIGURA 5-Dispositivo de formato cilindrico, confeccionado em latão.................................14

FIGURA 6-Sulco interno para acomodação óssea ................................................................. 14

FIGURA 7-Desgaste realizado nas partes proximais do dispositivo .......................................15

FIGURA 8-Utilização da Resina Acrílica Auto Polimerizante, para evitar o escorregamento do espécime dentro do dispositivo..................................................................................... 16

FIGURA 9-Mudanças ocorridas no tamanho e formato da placa de aço inóx, sendo 1,2 e 3 a

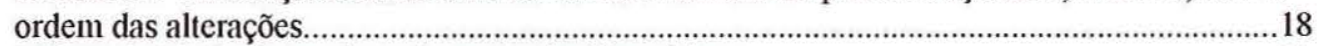

FIGURA 10-Conjunto das três partes do dispositivo..............................................................19

FIGURA 11-Posicionamento do espécime em 90 graus de flexão........................................20

FIGURA 12-Diagrama de colunas com os valores de Média e Desvio Padrão para Carga Máxima, no grupo de avaliação metodológica.........................................................................24

FIGURA 13-Diagrama de colunas com os valores de Média e Desvio Padrão para

Deformação Máxima, no grupo de avaliação metodológica................................................25

FIGURA 14-Diagrama de colunas com os valores de Média e Desvio Padrão para Energia, no grupo de avaliação metodológica..................................................................................27

FIGURA 15-Diagrama de colunas com os valores de Média e Desvio Padrão para Rigidez, no grupo de avaliação metodológica................................................................................28

FIGURA 16-Diagrama de colunas com os valores de Média e Desvio Padrão para Carga Máxima, no grupo imobilizado.............................................................................................30

FIGURA 17-Diagrama de colunas com os valores de Média e Desvio Padrão para

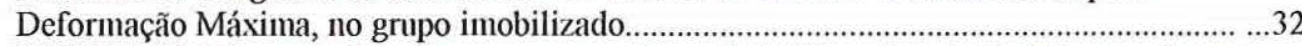

FIGURA 18-Diagrama de colunas com os valores de Média e Desvio Padrão para Energia,

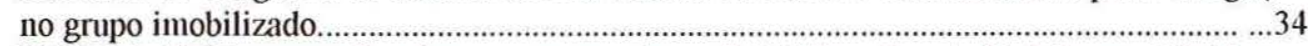
FIGURA 19-Diagrama de colunas com os valores de Média e Desvio Padrão para Rigidez, no grupo imobilizado 


\section{LISTA DE TABELAS}

TABELA 1- Valores de Carga Máxima apresentados pelo ligamento cruzado anterior, no ensaio mecânico de tração, para o grupo de avaliação metodológica.

TABELA 2-Valores da Média e do Desvio Padrão, em relação à Carga Máxima, para o grupo de avaliação metodológica

TABELA 3- Valores de Deformação Máxima, para o grupo de avaliação metodológica... ...24

TABELA 4- Valores da Média e do Desvio Padrão, em relação à Deformação Máxima, para

o grupo de avaliação metodológica.

TABELA 5- Valores de Energia, para o grupo de avaliação metodológica. .26

TABELA 6- Valores da Média e do Desvio Padrão, em relação à Energia, para o grupo de avaliação metodológica.

TABELA 7- Valores de Rigidez apresentados pelo ligamento cruzado anterior, no ensaio mecânico de tração, para o grupo de avaliação metodológica.

TABELA 8- Valores da Média e do Desvio Padrão, em relação à Rigidez, para o grupo de avaliação metodológica

TABELA 9- Valores de Carga Máxima, para o grupo imobilizado

TABELA 10-Valores da Média e do Desvio Padrão, em relação à Carga Máxima, para o grupo imobilizado.

TABELA 11- Valores de Deformação Máxima, para o grupo imobilizado.

TABELA 12-Valores da Média e Desvio Padrão, em relação à Deformação Máxima, para o grupo imobilizado.

TABELA 13- Valores de Energia Absorvida para o grupo imobilizado.

TABELA 14-Valores de Média e Desvio Padrão, em relação à Energia Absorvida, para o grupo imobilizado..

TABELA 15- Valores de Rigidez, para o grupo imobilizado.

TABELA 16- Valores da Média e do Desvio Padrão, em relação à Rigidez. 


\section{RESUMO}

DOMINGOS, C. S. P. (1998). Efeito da imobilização na resistência mecânica do ligamento cruzado anterior. Ribeirão Preto, 1998. 65p. Dissertação (Mestrado) - Faculdade de Medicina de Ribeirão Preto e Escola de Engenharia de São Carlos, Universidade de São Paulo.

O efeito da imobilização no ligamento cruzado anterior, através de atadura gessada por um período de 6 semanas, foi estudado em ratos machos, adultos da raça Wistar. Para esta análise foram desenvolvidos dispositivos que permitiram a fixação do espécime à Máquina de Ensaio Universal e a realização de ensaio mecânico de tração. Através desta metodologia a tração foi aplicada na interlinha articular, somente na junção osso-ligamento-osso. Os dados obtidos foram analisados, quanto à carga máxima, deformação máxima, e energia absorvida pelo ligamento até o momento da ruptura. Nos resultados obtidos não foi observado diferença estatisticamente significativa na resistência do ligamento cruzado anterior, do membro imobilizado em relação ao membro não imobilizado, o que nos indica que provavelmente um período de 6 semanas de imobilização o qual permite pequeno grau de movimento como é o caso da imobilização gessada, não foram suficientes para produzir alterações na resistência ligamentar.

Palavras-chave: ligamento cruzado anterior; imobilização; resistência mecânica, ensaio mecânico de tração; joelho; rato. 


\begin{abstract}
DOMINGOS, C. S. P. (1998). Immobilization effects on strenght of the rat anterior cruciate ligament. Ribeirão Preto, 1998. 65p. Dissertação (Mestrado) - Faculdade de Medicina de Ribeirão Preto e Escola de Engenharia de São Carlos, Universidade de São Paulo.
\end{abstract}

The effects of immobilization through plaster cast for 6 weeks on the mechanical properties of the anterior cruciate ligament (ACL) of Wistar adult male rats were analysed.

Special grips for retaining the specimens during traction tests in a universal test machine were developed. In this way, traction forces could be applied directly to bone-ligament-bone complex. Maximal load, maximal deformation, stiffness and absorbed energy up to the rupture point were considered, compared to the contralateral (normal) ACL. No significant difference could be demonstrated leading us to the conclusion that, at least for the considered lenght of time of immobilization (6 weeks), no important changing in the mechanical properties of the LCA occurred. This contradictory result compared to others in the literature was imputed to the different methodology here employed, where the forces could be applied directly to bone-ligament-bone complex, instead of the femur, anterior cruciate ligament and part of tibia. In addition, the relativily short period by immobilization and the movement permited by the slack immobilization could also be responsabilite for the results.

Keywords: anterior cruciate ligament; immobilization; strength mechanics, tensile mechanical test, knee; rat. 


\section{INTRODUÇÃO}

A imobilização tem sido a terapia mais comum para as desordens musculoesqueléticas desde os tempos de HIPÓCRATES. No século passado HUGH OWEN THOMAS, ROBERT JONES e REGINALD WATSON- JONES foram fortes preconizadores da imobilização para tratamento de fraturas e condições inflamatórias (AKESON et al, 1986).

Segundo EVANS et al (1960) a imobilização como forma terapêutica se iniciou com MENZEL (1871).

Repouso, imobilização, reparação cirúrgica e exercícios, têm sido freqüentemente prescritos para reabilitar indivíduos com lesões ligamentares (TIPTON et al, 1967b). Ainda hoje a cirurgia ortopédica se defronta com o desafio de conduzir de maneira eficaz o tratamento das lesões ligamentares.

No entanto, os efeitos adversos da imobilização sobre a articulação somente foram reconhecidos no século XIX por LUCAS-CHAMPONNIERE e mais tarde por GEORGE PERKINS, embora com alternativas terapêuticas pouco efetivas (AKESON et al, 1986).

Desde então alguns autores vêm tentando esclarecer as alterações histológicas e bioquímicas decorrentes da imobilização, com o intuito de estabelecer relação destas alterações com modificações mecânicas que possam vir a ocorrer com o ligamento. 
EVANS et al (1960), destacaram 3 fatores importantes que determinam a extensão das alterações articulares devido à imobilização, que são: grau de restrição de movimento, friç̧ão entre as áreas de contato, pressão entre as áreas de contato.

E ao estudarem os efeitos da imobilização com fixação interna através de fios de Kirschner, com períodos diferentes de 15 à 90 dias, constataram que estas alterações podem ser observadas tanto macroscopicamente, pela proliferação de tecido gorduroso, espessamento da gordura de Hoffa, cartilagem de coloração mais acinzentada e menos brilhante, como também microscopicamente, com proliferação de tecido conectivo, afinamento da cartilagem e até alteração no osso subcondral nas áreas abaixo das lesões cartilaginosas. No entanto, estas alterações tendem a progredir com o aumento do tempo de imobilização. A maioria se estabelece com período de 60 dias de imobilização, mas outras alterações, como proliferação de tecido conectivo, já são observadas com 15 dias e se apresentam bem estabelecidas com 30 dias e se mantêm sem alterações adicionais até 60 dias, quando ocorre aumento na densidade.

TIPTON et al (1967a), pesquisando ligamento colateral medial de ratos SpragueDawley, imobilizados através de fixação ințerna com fio de Kirschner por 6 semanas e outro grupo privado de movimento com tenotomias por 8-9 semanas, observaram diminuição na carga suportada por este ligamento nos dois grupos. Os ligamentos imobilizados apresentaram elasticidade menor em relação ao não imobilizado.

BOOTH \& TIPTON (1970), comparando a resistência do ligamento colateral medial de ratos da raça Sprague-Dawley, na pré-puberdade e puberdade, entre machos e fềmeas, constataram que na pré-puberdade não houve diferença significativa no peso do animal e na carga suportada pelo ligamento entre machos e fềmeas, mas que, na puberdade, tanto o peso como a carga foram maiores nos machos. No entanto, quando se comparava a carga suportada pelo ligamento em relação ao peso e a idade do animal, esta foi maior nas fềmeas. 
TIPTON et al (1978), ainda estudando o ligamento colateral medial em ratos Sprague-Dawley, observaram a influência da idade e sexo na resistência da junção ossoligamento-osso, confirmando o que eles já haviam observado no trabalho anterior, ou seja, quanto maior o peso, maior a carga suportada pelo ligamento. Como os machos tinham um crescimento mais rápido, apresentaram maior resistência ligamentar, mas, quando comparado idade em relação ao peso, a resistência ligamentar for maior nas fềmeas.

Estes achados já haviam sido observados anteriormente por SMITH (1954), que ao verificar as propriedades elásticas do ligamento cruzado anterior em coelhos, encontrou que a resistência deste ligamento está relacionada ao peso corporal do animal.

AKESON et al (1986), mencionaram que os efeitos da imobilização na articulação sinovial são profundos, tanto nos tecidos intrarticulares como extrarticulares. Segundo eles há uma diminuição no paralelismo das fibras de colágeno no ligamento cruzado anterior de animais após 9 semanas de imobilização.

Quanto às mudanças bioquímicas, estes autores relataram uma redução de $10 \%$ na quantidade de colágeno, aumento da degradação e síntese de colágeno e redução de 3-4\% no conteúdo hídrico. Todas estas alterações relatadas têm implicações clínicas, uma vez que elas levam também a transtornos biomecânicos no ligamento. Eles encontraram atrofia muscular e início de proliferação de tecido adiposo com 2 semanas de imobilização e com 30 à 60 dias, desenvolvimento de aderências. Após 60 dias notaram presença de ulcerações da cartilagem nas áreas de compressão e proliferação fibrovascular no osso subcondral, sendo que os efeitos na cartilagem persistiram inclusive após a remobilização.

Segundo ZUCKERMAN \& STULL (1969), um levantamento realizado na Universidade de Harvard sobre a freqüência e natureza das lesões do esporte concluiu que as lesões de joelho foram as mais freqüentes nos últimos 22 anos, em relação às lesões em outras partes do corpo, o que pode ser entendido levando-se em consideração que o joelho é uma articulação extremamente exposta a lesões traumáticas, porque os ossos que a compõem 
formam um grande braço de alavanca, dependendo assim, de uma combinação perfeita de músculos e ligamentos para assegurar-lhe estabilidade.

Nas últimas décadas é crescente a quantidade de pessoas praticando atividades esportivas, o que muitas vezes repercute em grande incidência de lesões ligamentares do joelho, principalmente do ligamento cruzado anterior, tornando este ligamento alvo de pesquisa de muitos trabalhos. Segundo JOHNSON (1983), das lesões ligamentares, sua insuficiência é considerada a maior causa de incapacidade permanente.

CABAUD et al (1980), comentam que o ligamento cruzado anterior é uma estrutura peculiar, da qual todos os mamíferos terrestres, dependem para estabilizar a sua articulação do joelho.

As articulações são estabilizadas pelos ligamentos, os quais são bandas de tecido conjuntivo resistentes, que atravessam as juntas do corpo dando estabilidade. Em décadas passadas pensava-se que os ligamentos eram estruturas estáticas designadas somente para manter o alinhamento do esqueleto. No entanto, atualmente, já se identificou outras funções, sendo que experimentos laboratoriais têm demonstrado que os ligamentos apresentam comportamento biomecânico bastante complexo, proporcionando primariamente estabilização das articulações e também assistindo a outras estruturas a manter a cinemática normal da articulação. Eles são formados de $70-80 \%$ de fibras de colágeno, organizadas de modo paralelo ao longo do seu comprimento e resistem a forças de tensão, sendo anatomicamente posicionados e estruturalmente designados para guiar o movimento normal e limitar os movimentos anormais (WOO et al, 1994).

De acordo com AKESON et al (1986), estas estruturas fibrosas são inervadas com terminais proprioceptivos, que têm a capacidade de avisar os centros superiores para que ocorram respostas musculares compensatórias quando uma tensão excessiva for aplicada na articulação. 
Na grande maioria das situações experimentais a ruptura ligamentar ocorre na zona de inserção ligamentar (MILTNER et al, 1937; HORWITZ, 1939; MARTIN, 1960; TIPTON et al, 1967a; WOO et al, 1994).

TIPTON et al (1967b), mencionam a abertura na placa de crescimento antes da ruptura ligamentar, ao se realizar o ensaio mecânico de tração. E trabalhos mais recentes como o de WOO et al (1994), ainda comentam sobre as dificuldades em se realizar ruptura ligamentar experimental, pois normalmente ocorre deslizamento do espécime na garra, pois este geralmente é bastante pequeno, o que dificulta a fixação.

Constitui propósito do presente trabalho verificar se existe alteração na resistência mecânica ligamentar, após imobilização gessada, sendo o ligamento cruzado anterior escolhido para a realização deste trabalho, devido à grande incidência de lesões no atleta, com implicações clínicas relevantes. 


\section{MATERIAL E MÉTODO}

\subsection{ANIMAL UTILIZADO:}

Neste trabalho foram utilizados 62 ratos da linhagem Wistar, machos, adultos, com peso entre 300 e $400 \mathrm{~g}$. Os animais foram fornecidos pelo Biotério Central do Campus da USP de Ribeirão Preto e mantidos no Biotério do Laboratório de Bioengenharia da Faculdade de Medicina de Ribeirão Preto - USP.

Os animais foram mantidos em gaiolas com no máximo 5 animais cada e receberam ração comercial e água "ad libitum", e divididos em 2 grupos sendo:

- grupo de avaliação metodológica : 10 animais, os quais não sofreram nenhum tratamento, e foi criado com o objetivo de verificar a confiabilidade na metodologia utilizada no experimento.

" grupo imobilizado: 52 animais, os quais tiveram seus membros posteriores esquerdos imobilizados por 6 semanas, e seus membros posteriores direitos utilizados como controle.

\subsection{MÉTODO DE IMOBILIZAÇÃO:}

\subsubsection{Evolução do Método de Imobilização}

Para se chegar à metodologia adequada para colocação da atadura gessada, foi realizado um trabalho piloto com vários animais. 
Como os ratos são roedores, foram encontradas algumas dificuldades para manter estes animais imobilizados por 6 semanas. Por isso, vários métodos de imobilização foram testados.

Numa primeira tentativa o animal teve o seu membro posterior esquerdo imobilizado com atadura gessada, mantendo o joelho em extensão, sem a colocação de alguma proteção para a pele do animal, nem se preocupar com a posição do quadril ou tornozelo, uma vez que até este momento não se tinha conhecimento de algumas dificuldades que foram encontradas. Antes de se iniciar este trabalho piloto, o único transtorno previsto era que, no decorrer de 6 semanas, o gesso provavelmente seria roído pelo animal. No entanto, somente algumas horas foram necessárias para que o animal retirasse o gesso, sem que houvesse necessidade de roê-lo, simplesmente fazendo-o escorregar.

Foi então, colocada maior pressão na colocação da atadura para dificultar a retirada da mesma pelo animal. Como conseqüência, a extremidade distal do membro imobilizado, se apresentou bastante edemaciada e cianótica após algumas horas.

A atadura gessada foi passada então, não somente no membro posterior esquerdo, mas na região abdominal, o que fez com que os animais roessem o gesso por não conseguirem retirá-lo.

A região do tornozelo, foi então, envolvida com tira de algodão, para se evitar a compressão vascular. Assim o problema do edema e da cianose foram eliminados, mas houve a retirada do gesso por alguns animais, e os que permaneceram imobilizados, apresentaram lesões de pele pelo atrito nas partes de maior pressão.

Com o objetivo de proteger a pele do animal, todo o membro posterior foi protegido com algodão. Isto fez com que os animais que permaneceram com o gesso não apresentassem lesão de pele. No entanto, a maioria voltou a retirar o gesso com bastante facilidade. 
Para dificultar a retirada do gesso, o membro posterior esquerdo foi posicionado em abdução de quadril, como sugerem MARCONDES DE SOUZA et al. (1964). De todas as tentativas, esta foi a de menor incidência de retirada do gesso pelo animal.

Com o objetivo, de encontrar uma metodologia, na qual a incidência de retirada do gesso fosse ainda menor, foi confeccionado uma órtese para imobilização, em material termo-elástico utilizado por terapeutas ocupacionais na confecção de órteses. Por ser este material mais rígido e resistente que o gesso, após o seu resfriamento, acreditava-se que este método dificultaria que o animal roesse o mesmo. No entanto, os animais não conseguiram roer a órtese, mas esta não conseguiu imobilizar satisfatoriamente a articulação do joelho e os animais conseguiram retirá-la.

O método onde se obteve os melhores resultados, foi quando o animal tinha proteção no tornozelo, e imobilização com o quadril em abdução. Foi então, colocado colar cervical de material plástico, o qual impedia o acesso da boca do animal ao gesso. Desta forma, o problema da retirada do gesso foi eliminado. Porém, o animal apresentou-se bastante estressado dada a agitação que este manifestava, então esta conduta foi suspensa por temer que o animal não resistisse 6 semanas nestas condições.

Diante destas tentativas, a metodologia utilizada foi a imobilização do membro posterior esquerdo, pela passagem da atadura gessada pela região abdominal. Foram utilizadas ataduras gessadas de endurecimento rápido $\left(\mathrm{Cremer}^{\circledR}\right)$. Estas apresentavam medidas próprias $(20 \mathrm{~cm}$ de largura) para uso em humanos. Cada atadura teve seu comprimento reduzido à metade e foi cortada em cinco partes com $4 \mathrm{~cm}$ de largura cada, fornecendo então cada atadura comercial, dez ataduras modificadas. Para imobilização de cada animal foi necessária a utilização de duas ataduras.

Os animais foram previamente anestesiados com inalação de éter sulfúrico. Antes de ser colocada a atadura gessada, o tornozelo do animal foi protegido com tira de flanela, com a finalidade de evitar a compressão vascular e ferimentos nesta região (FIGURA 1). A 
atadura era então passada pelo membro posterior esquerdo e pela região do abdômen, mantendo o quadril em abdução. (FIGURA 2)

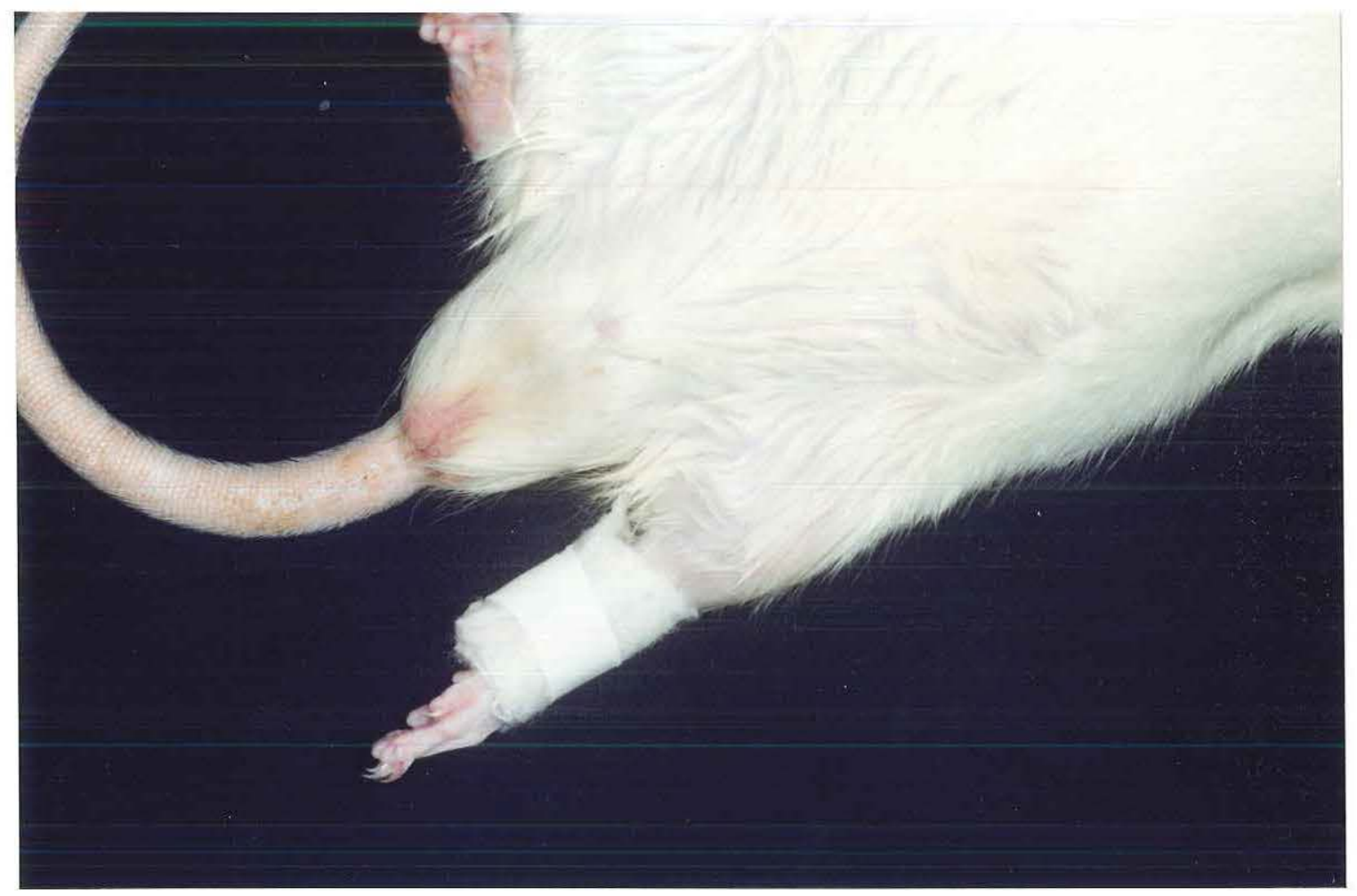

FIGURA 1-Proteção com tira de flanela, para proteger a região do tornozelo contra o gesso 


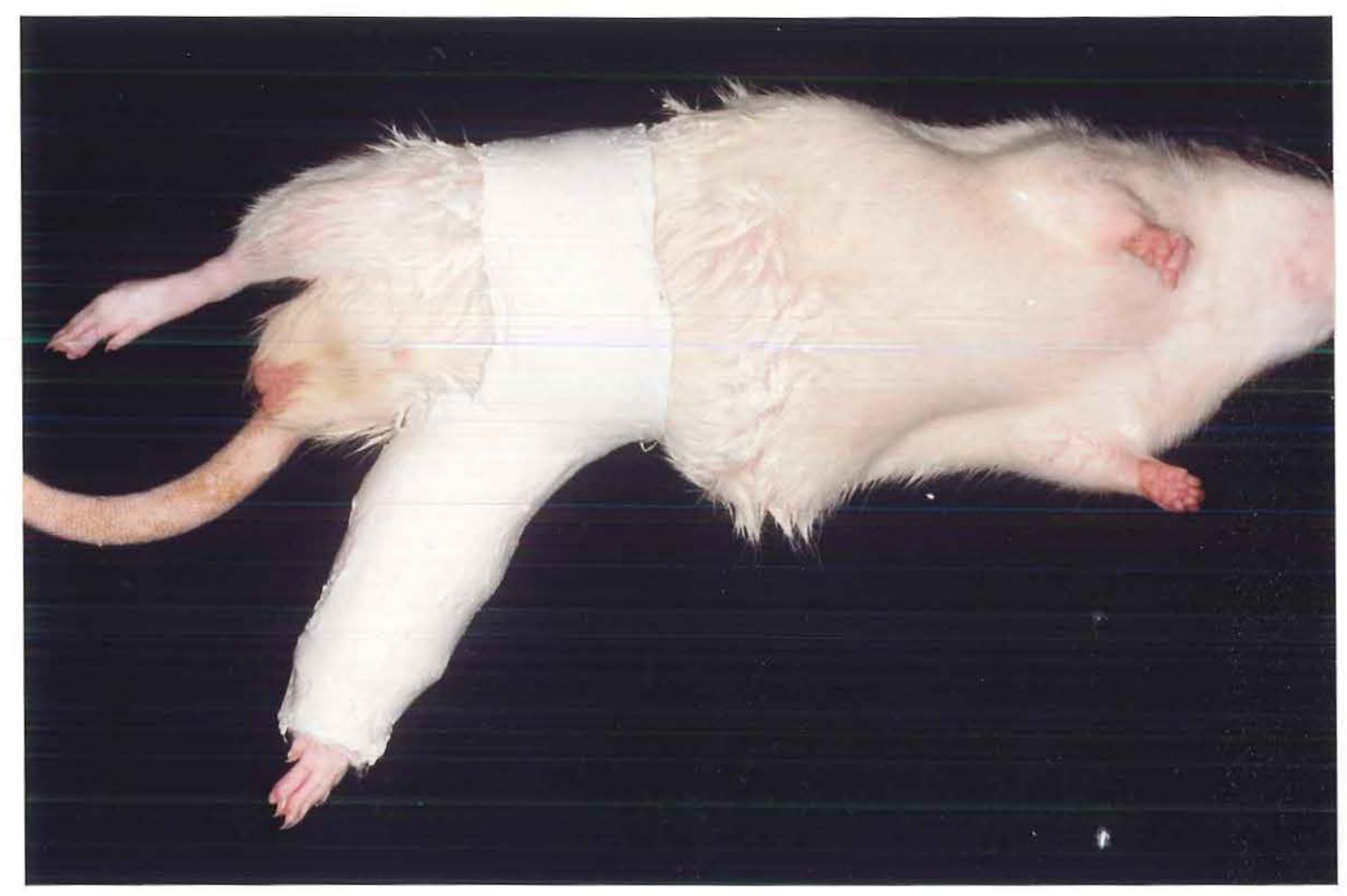

FIGURA 2-Colocação da atadura gessada no membro posterior esquerdo e região do abdômen.

Os animais foram observados duas vezes ao dia, para verificar a ocorrência de retirada do gesso pelo animal, presença de edema da pata imobilizada e existência de ferimentos na pele do animal causados pelo atrito com o gesso. Quando o animal retirava o gesso ou quando apresentava edema, o gesso era imediatamente recolocado. Quando haviam lesões de pele, era feito o uso de Lepecid ${ }^{1}$ spray $^{\circledR}$.

\footnotetext{
${ }^{1}$ Composição: 0,0-dietil-0,3,5,6-tricloro-2-piridil fosforotioato, grupo químico fosforado Indicação: assepsia, aceleração processos de cicatrização e controle de bicheira Fabricação: Dow Química
} 


\subsection{TÉCNICA UTILIZADA PARA SACRIFICAR OS ANIMAIS:}

Ao final do período de 6 semanas de imobilização os animais foram sacrificados com inalação excessiva de éter sulfúrico, e tiveram seus membros posteriores direito e esquerdo desarticulados no quadril.

\subsection{DISSECCC̃̃O:}

Os membros foram dissecados com o auxílio de tesoura e pinça para retirada de partes moles, fibula e pata do animal. Depois, com o auxílio de lupa, bisturi e lâmina de bisturi número 15 , foi realizada a retirada da cápsula articular, meniscos e ligamentos, com exceção do ligamento cruzado anterior (LCA).(FIGURA 3)

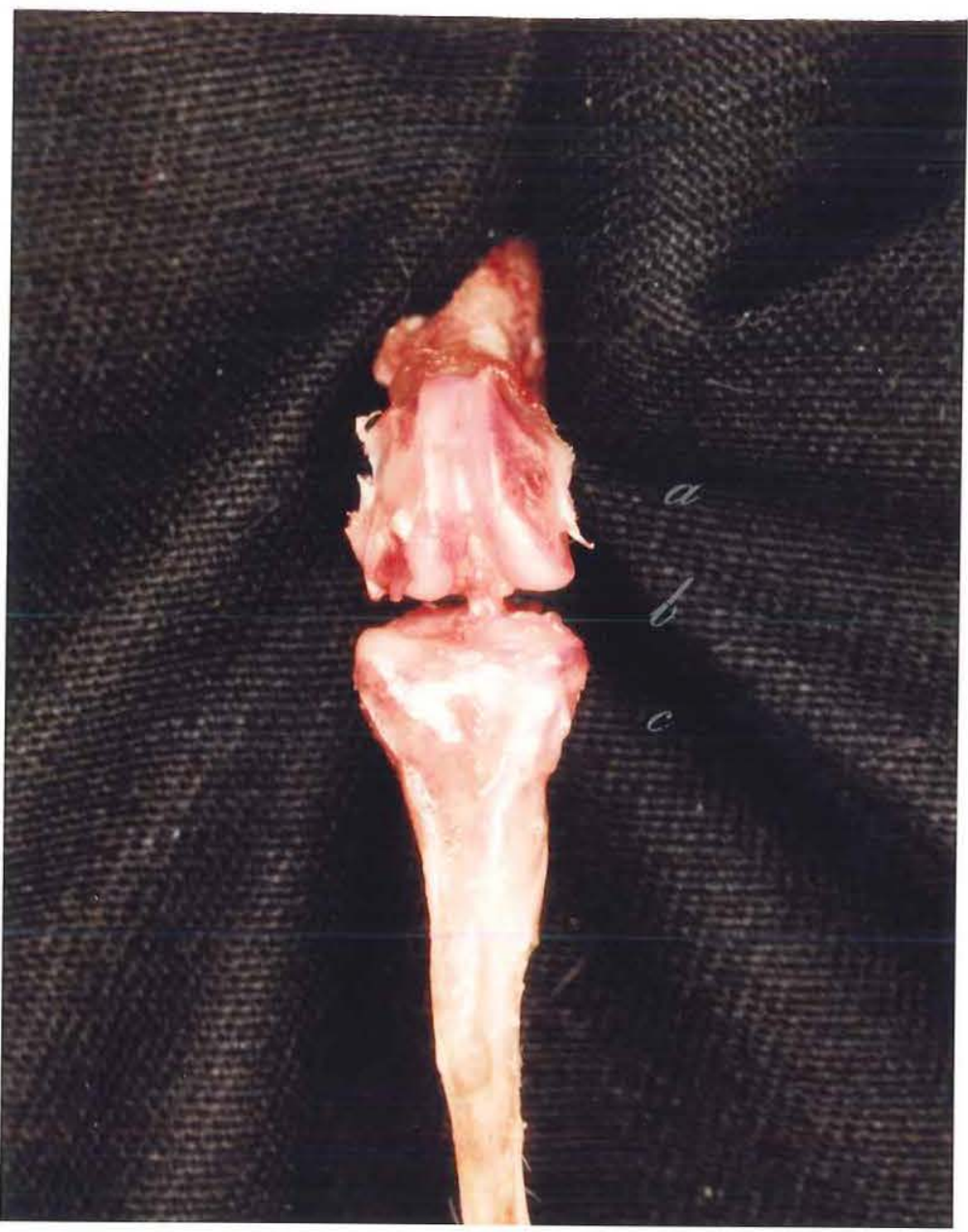

FIGURA 3-Espécime após dissecção (a-Fêmur , b-LCA, c-Tíbia) 


\subsection{MÉTODO DE CONSERVAÇÃO DO ESPÉCIME:}

Os espécimes foram congelados em freezer a - 20C, pois este método não altera de forma importante as propriedades mecânicas do ligamento. (ENWEMEKA et al ,1990 e WOO et al, 1994). Durante o ensaio, os ligamentos foram gotejados com soro fisiológico, para que não desidratassem evitando, assim, possível modificação das propriedades mecânicas.

\subsection{ENSAIO MECÂNICO DE TRAÇÃO}

A resistência do ligamento cruzado anterior (LCA) foi testada com ensaio mecânico de tração, sendo para isso utilizado uma Máquina Universal de Ensaio.(FIGURA 4)

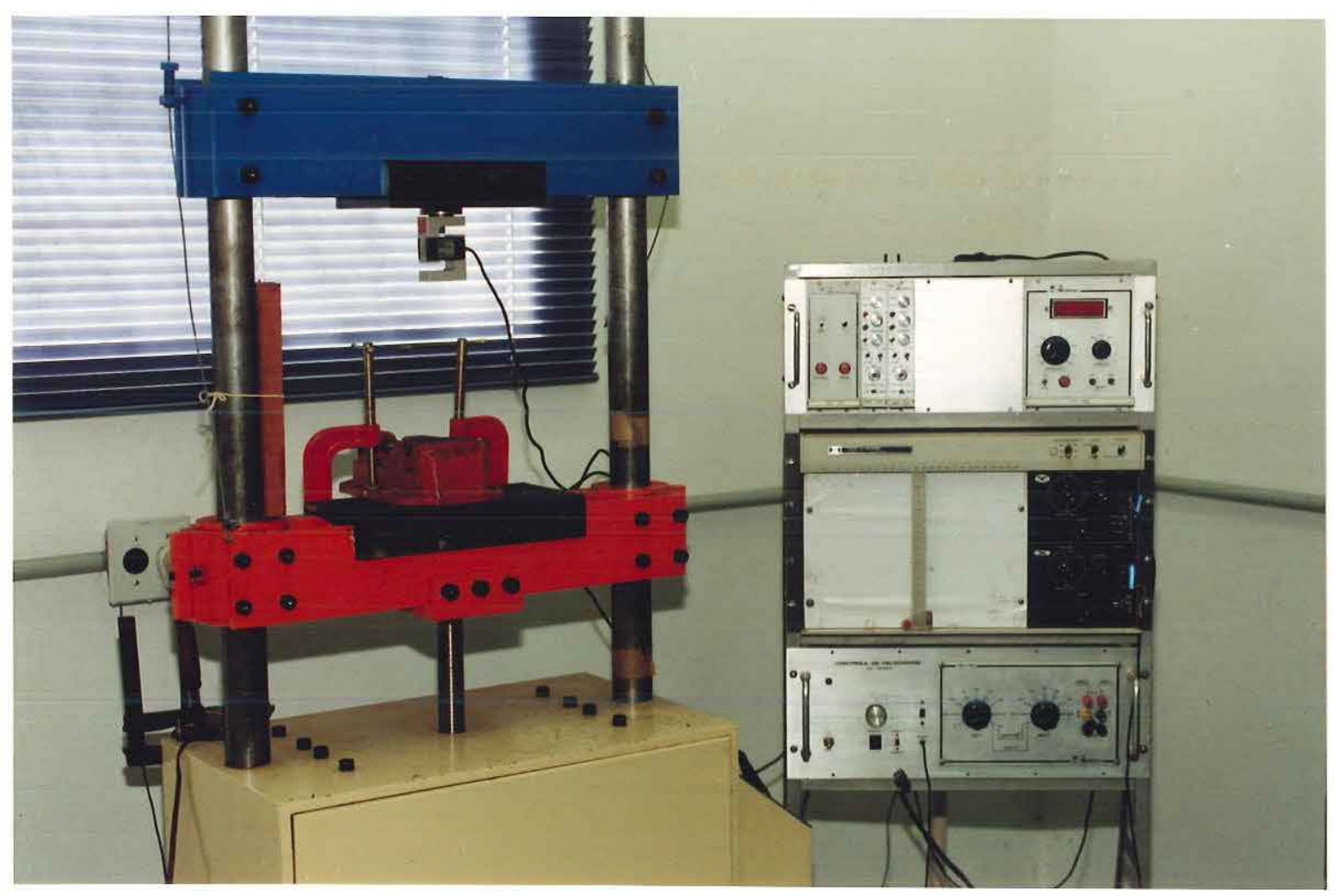

FIGURA 4-Vista geral da máquina universal de ensaio do Laboratório de Bioengenharia da Faculdade de Medicina de Ribeirão Preto/USP 
Para a execução do ensaio foi necessário o desenvolvimento de dispositivos apropriados para fixação do espécime, confeccionados pela Ofícina Mecânica de Precisão .

\subsubsection{Evolução da Metodologia Utilizada Para o Ensaio Mecânico de Tração}

Um trabalho piloto também foi realizado, com o objetivo de se definir a metodologia utilizada para fixação do espécime à Máquina de Ensaio Universal.

Inicialmente se tentou reproduzir a metodologia descrita por TIPTON et al (1967), através da fixação do espécime com a realização de orifícios aproximadamente a $1 \mathrm{~cm}$ acima dos côndilos no fêmur, e na extremidade distal da tíbia, onde eram atravessados por fios de aço. Não foi possível reproduzir satisfatoriamente sua metodologia, pois ocorreram fraturas esmagamento do osso no local de passagem dos fios e, na maioria, ocorreu abertura na placa de crescimento, uma vez que não somente o ligamento, mas a placa de crescimento está exposta as forças de tração no momento do ensaio.

Após as tentativas com os fios de aço, foram então, confeccionados dois dispositivos em latão, de formato cilíndrico, apresentando $4,5 \mathrm{~cm}$ de comprimento e $2,2 \mathrm{~cm}$ de diâmetro (FIGURA 5), e no sentido longitudinal, dividido em 2 partes, apresentando internamente um sulco que permitia a acomodação do fềmur e tíbia, sendo cada dispositivo fechado com 4 parafusos. (FIGURA 6) 


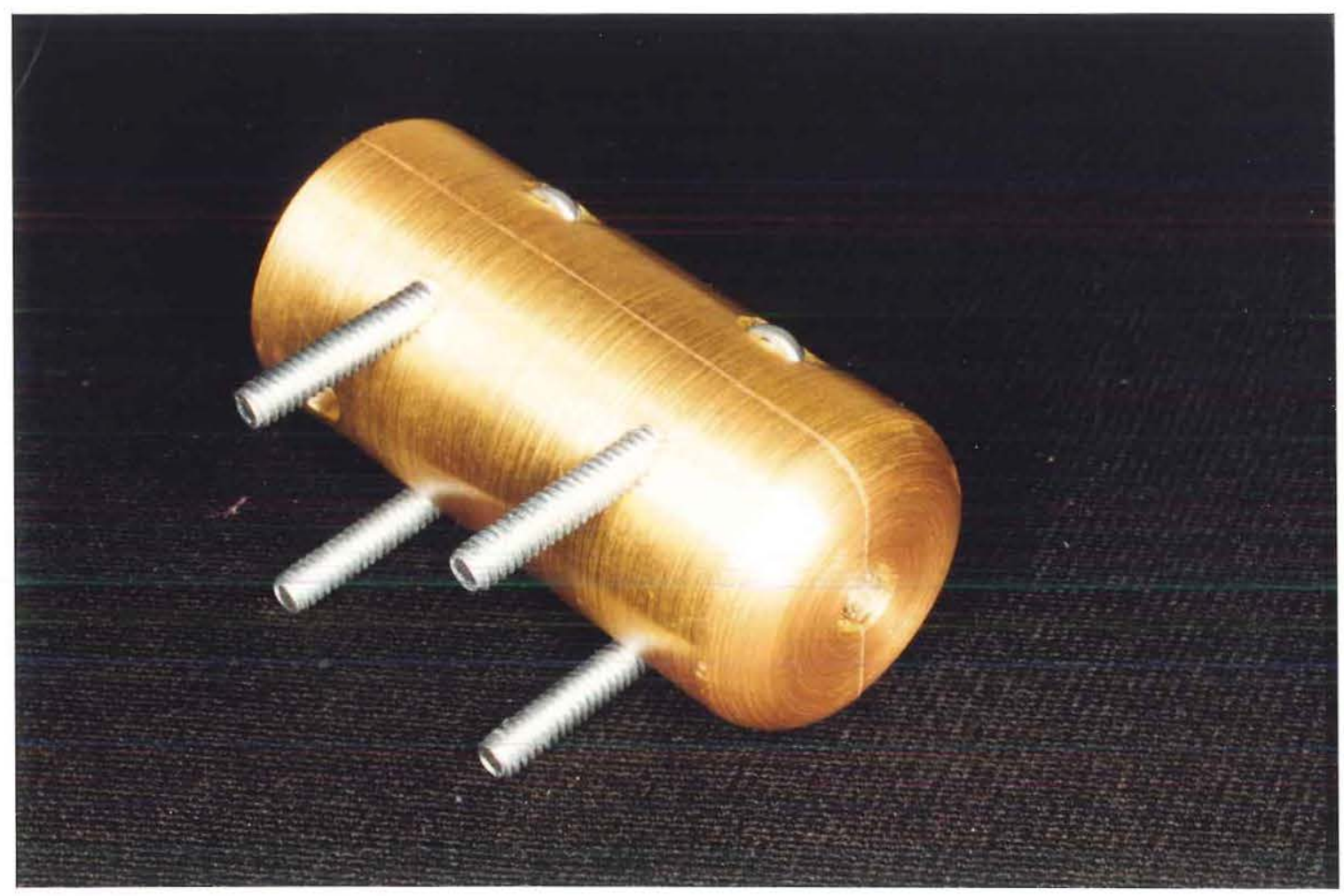

FIGURA 5-Dispositivo de formato cilindrico, confeccionado em latão.

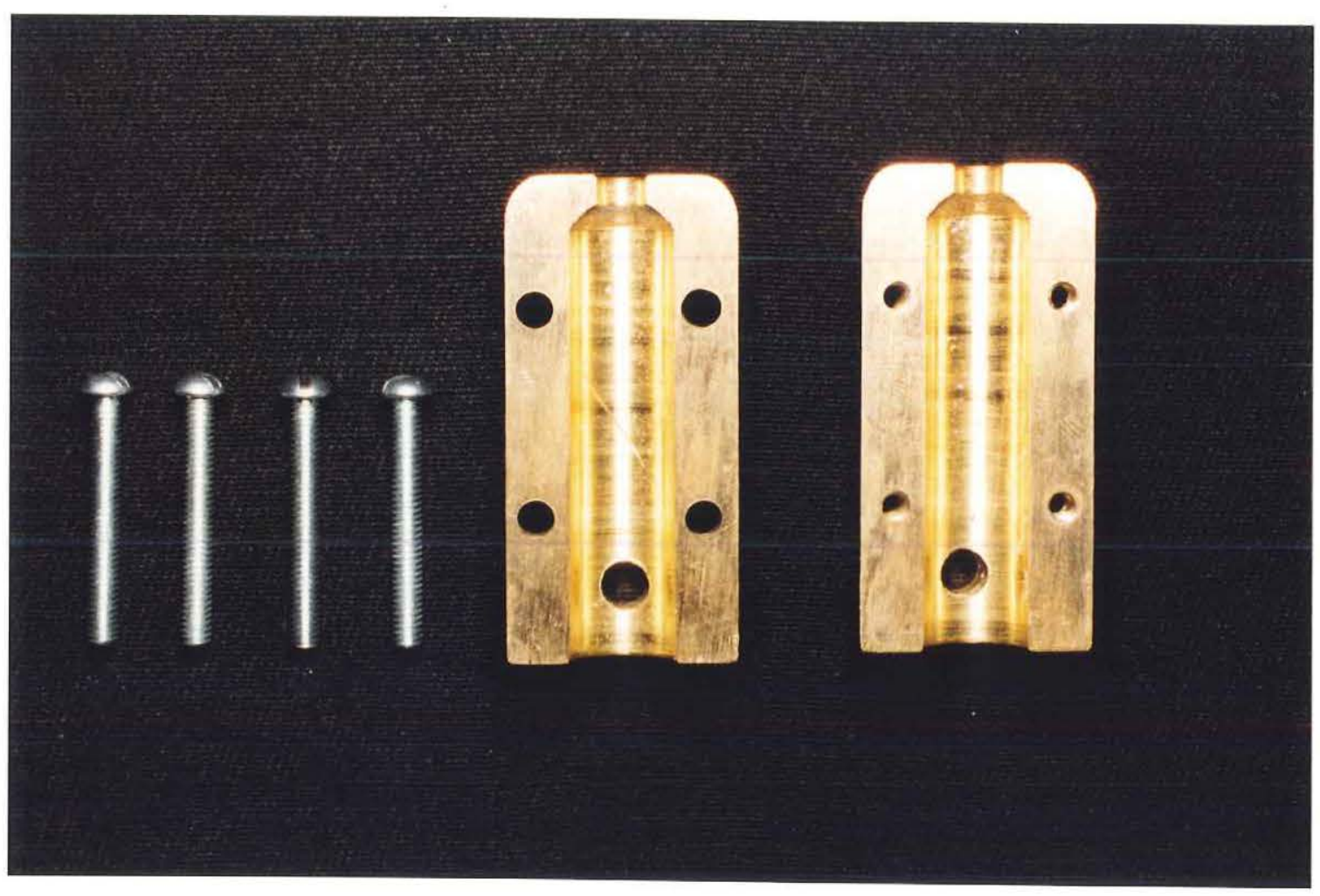

FIGURA 6-Sulco interno para acomodação óssea. 
Um dos dispositivos, era colocado no fêmur e o outro na tíbia, permanecendo entre estes, aproximadamente $2 \mathrm{~cm}$, onde se observava os côndilos femurais, ligamento cruzado anterior e platôs tibiais. A tração era realizada com o joelho em extensão. Durante a realização do ensaio mecânico de tração foi observado na maioria dos espécimes, um escorregamento do osso dentro do dispositivo.

Com o objetivo de evitar o escorregamento, se tentou fechar o dispositivo na interlinha articular, deixando entre os dispositivos somente o ligamento cruzado anterior, o que não se conseguiu devido ao espaço articular possível ser bastante estreito nestes animais.

Foi então, realizado desgaste da extremidade afunilada do dispositivo (FIGURA 7), restando assim uma lâmina bastante estreita.

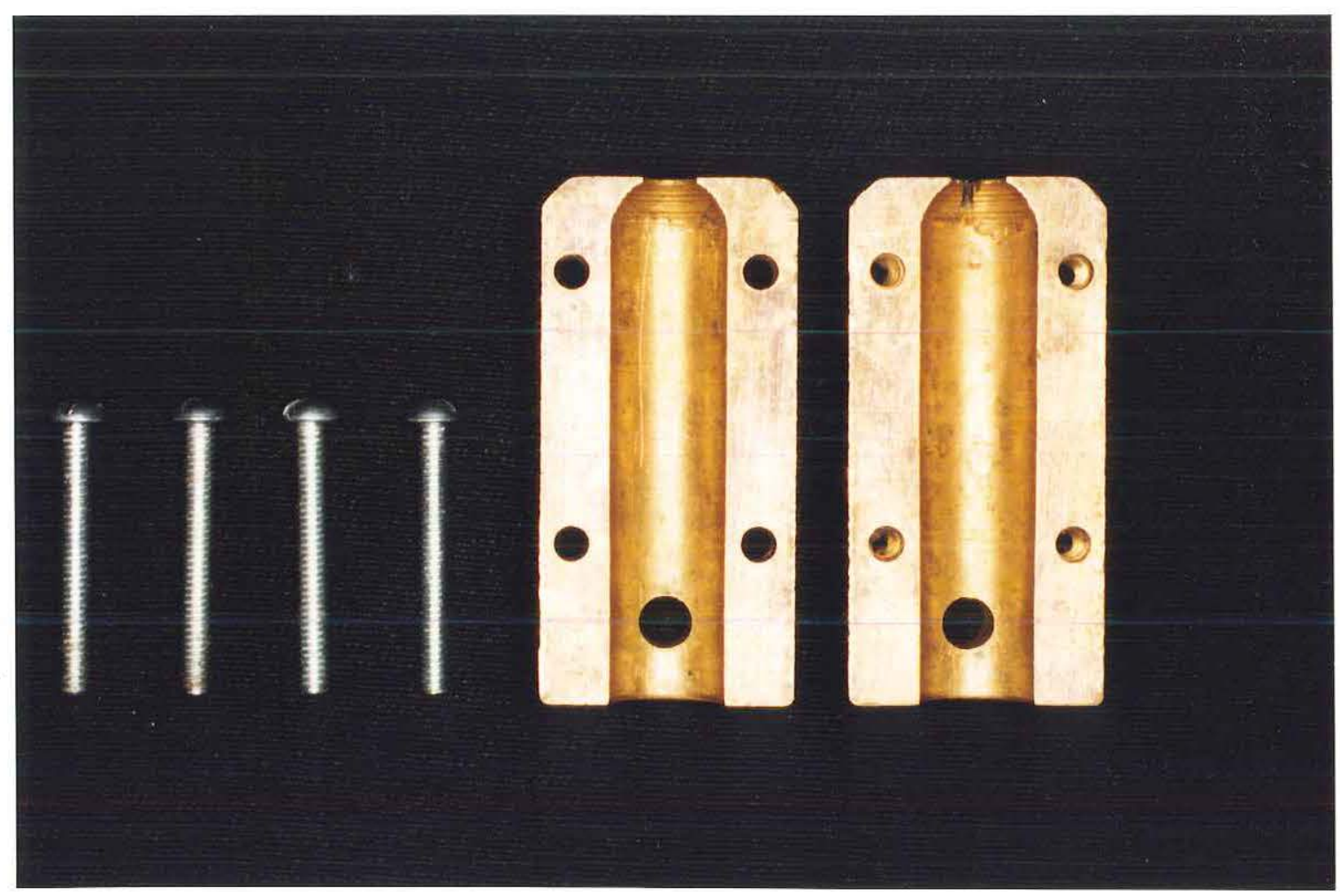


Nos animais em que foi possível fechar o dispositivo, o conjunto espécimedispositivo, apresentou-se bastante tenso, provavelmente já impondo uma certa carga ao ligamento, fazendo com que este método fosse porisso descartado.

A fixação na tíbia através dos platôs tibiais, foi então mantida, e no fêmur o dispositivo era fechado aproximadamente à $1 \mathrm{~cm}$ da interlinha articular, sendo o canal interno remanescente do mesmo, previamente preenchido com Resina Acrílica Auto Polimerizante Jet, de uso odontológico. (FIGURA 8)

O escorregamento do espécime dentro do dispositivo foi resolvido, mas a abertura na placa de crescimento do fêmur ocorreu novamente.

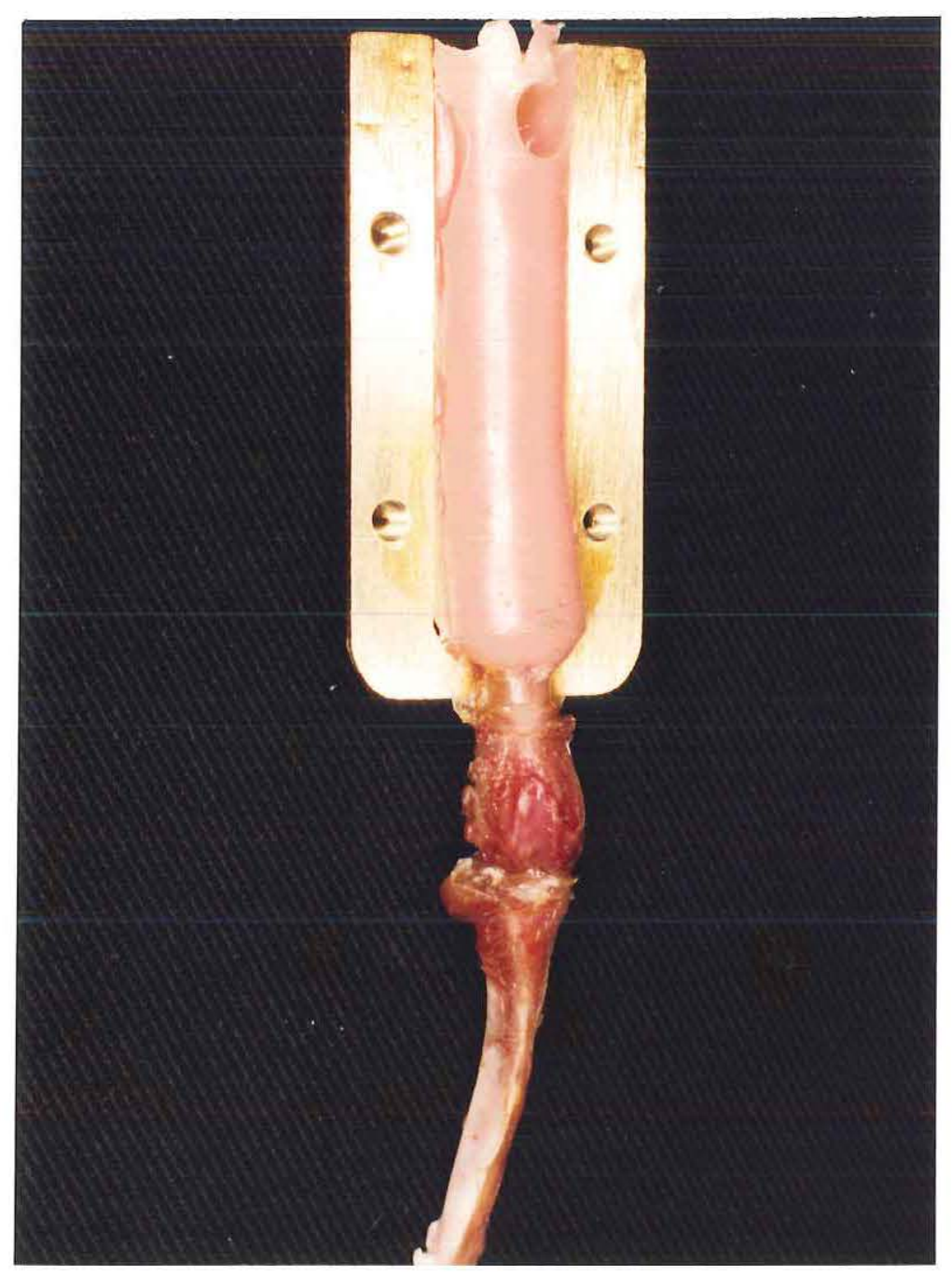


Foram então, solicitados animais considerados adultos para o Biotério Central da Faculdade de Medicina de Ribeirão Preto, e permaneceram no Laboratório de Bioengenharia por mais 2 meses, com o objetivo de se utilizar no ensaio mecânico de tração, animais que estivessem com suas placas de crescimento fechadas. Mas ao realizar o ensaio, continuou ocorrendo a abertura na placa de crescimento. Foram então, realizadas radiografias de alguns animais, se constatando que realmente as placas de crescimento ainda se encontravam abertas. Ao consultar a literatura, segundo JUNQUEIRA \& MARTINS (1947), as placas de crescimento destes animais não se fecham.

Diante destes fatos, ficou clara a necessidade de se desenvolver, um dispositivo, onde a tração ocorresse em nível da interlinha articular, pois desta forma, as dificuldades encontradas até o momento seriam eliminadas, como o escorregamento do espécime, abertura da placa de crescimento, e visando obter-se um resultado mais fidedigno sobre as alterações mecânicas decorrentes da imobilização, uma vez que, a tração estaria sendo aplicada somente na junção osso-ligamento-osso, e não, como apresentou a literatura consultada, na qual existe uma grande quantidade de tecido ósseo sendo tracionado, juntamente com o ligamento.

Foi então, mantida a metodologia de fixação da tíbia, e confeccionado um suporte femural a partir de uma placa de aço inóx de $9.0 \mathrm{~cm}$ de comprimento e $1.5 \mathrm{~cm}$ de largura e $0,1 \mathrm{~cm}$ de espessura. A placa era dobrada ao meio, apresentando então $4.5 \mathrm{~cm}$ de comprimento e foi confeccionada uma fenda para permitir a entrada e acomodação do ligamento, e em seguida revestida com película de Teflon para eliminar a possibilidade de corte de algumas fibras do ligamento pela borda cortante da fenda. Um orifício superior foi feito para fixação do suporte a célula de carga, através de parafuso.

O espécime entrava muito justo, deixando o conjunto espécime-dispositivo, ainda muito tenso, já imprimindo uma certa carga ao ligamento. 
Um desgaste lateral dos côndilos femurais foi realizado, com o objetivo de facilitar a colocação e melhorar a acomodação, no entanto, não houve melhora signifícativa.

A largura da placa foi aumentada até aproximadamente $2.0 \mathrm{~cm}$, e o local ocupado pelos côndilos femurais foi abaulado, em formato de circunferência, sendo o fêmur posicionado dentro da placa em $90^{\circ} \mathrm{com}$ a tíbia.

Os resultados foram bem próximos dos esperados. Em um deles porém, foi observado uma curva carga versus deformação diferente do que se vinha observando, o que se constatou ser devido à largura da placa não estar sendo suficiente para sustentar o fêmur em toda sua extensão, levando à movimentação do osso dentro do suporte durante o teste. Com o aumento da largura da placa para $4.0 \mathrm{~cm}$ de largura, $14.0 \mathrm{~cm}$ de comprimento (FIGURA 9) e moldada em formato adequado para acomodar o espécime este problema foi sanado, sendo esta metodologia empregada na execução do trabalho.

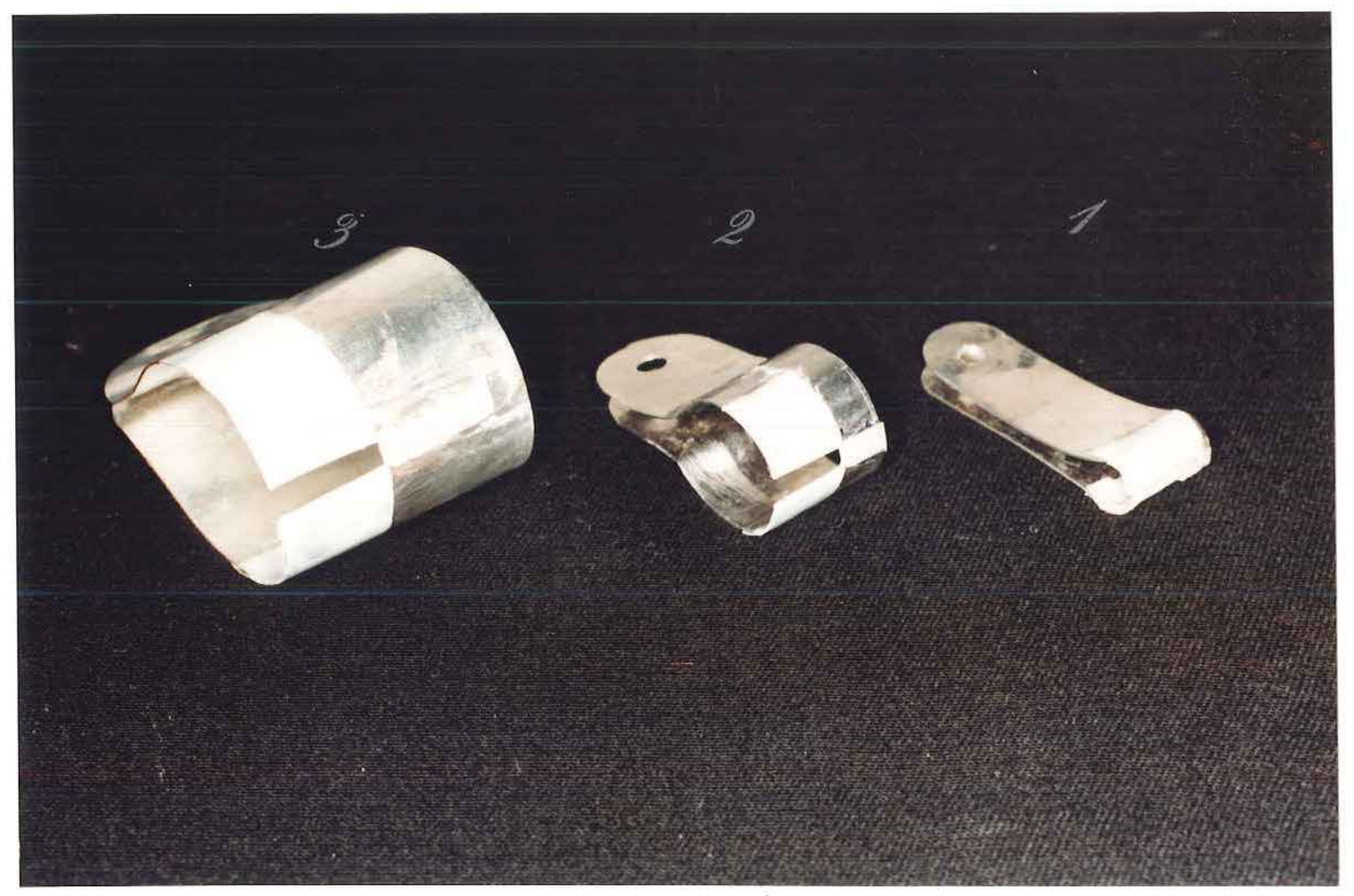

FIGURA 9-Mudanças ocorridas no tamanho e formato da placa de aço inóx, sendo 1, 2 e 3 a ordem das alterações. 
Um fio de aço dobrado foi utilizado para fixar o suporte de tíbia a um cilindro de latão, o qual foi preso à base de uma Máquina Universal de Ensaio, com o objetivo de permitir o livre alinhamento rotacional do espécime à medida que a carga era exercida. (FIGURA 10)

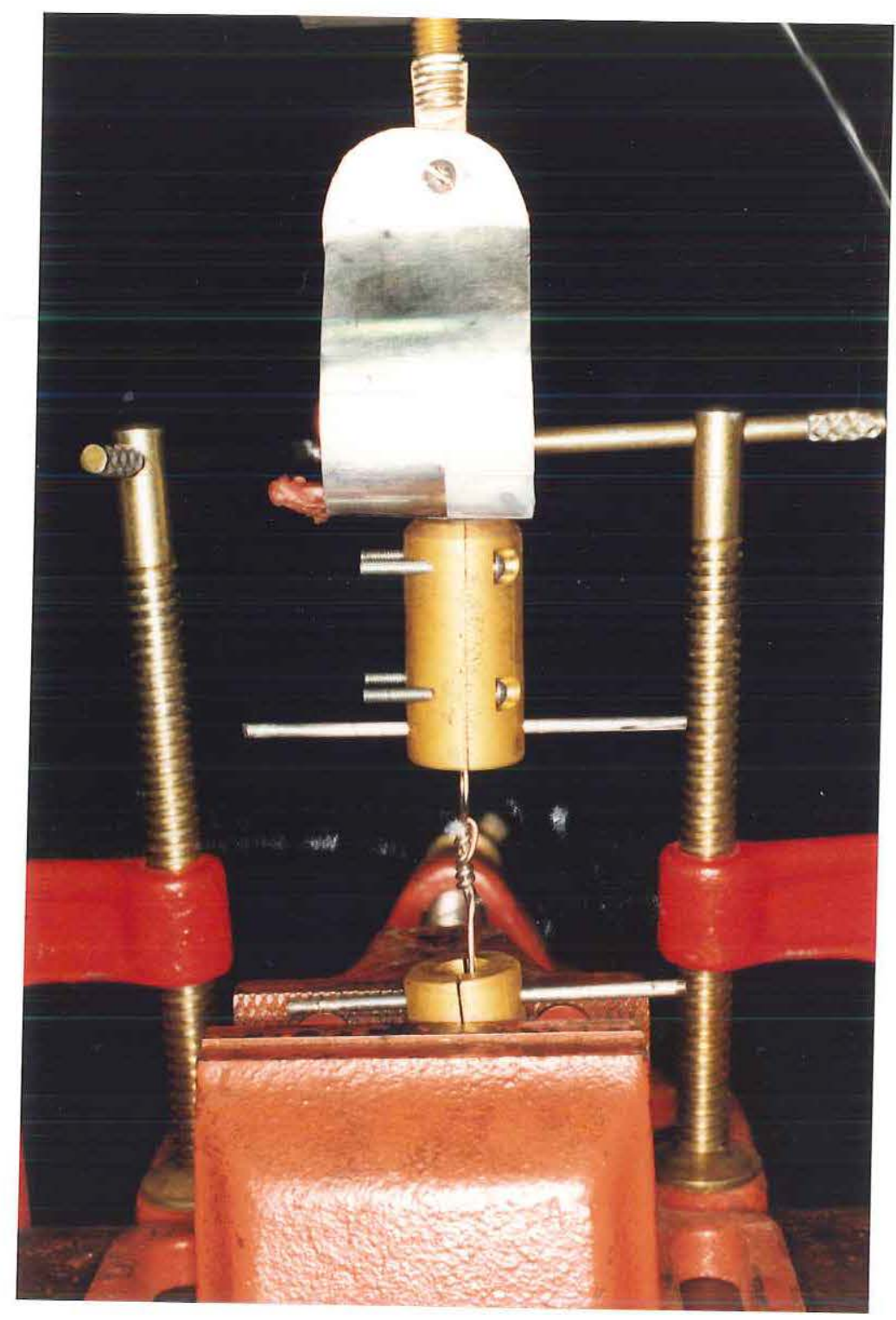

FIGURA 10-Conjunto das três partes do dispositivo.

O espécime foi mantido na garra com o fêmur em 90 graus de flexão de joelho, que era a posição à qual tendia a se estabilizar quando era aplicada a pré-carga. (FIGURA 11) 


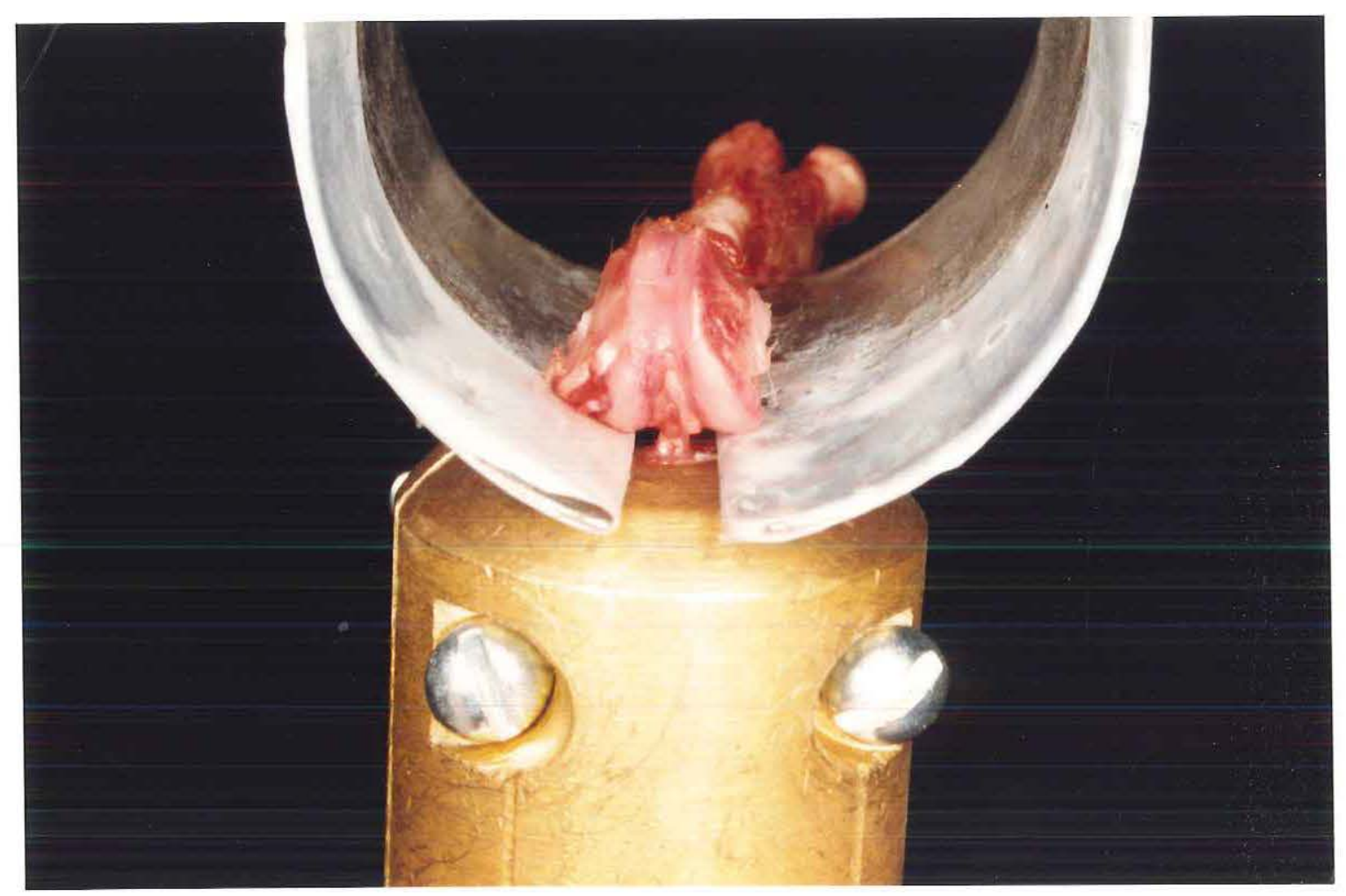

FIGURA 11-Posicionamento do espécime em 90 graus de flexão.

\subsubsection{Registro de Dados:}

Os ensaios foram realizados na velocidade de $0,25 \mathrm{~mm} / \mathrm{min}$. A força foi mensurada com célula de carga de $50 \mathrm{kgf}$ da marca $\operatorname{KRATOS}^{\circledR}$, modelo KM, acoplada a amplificador CAE 201 SODMEX $^{\circledR}$. As deformações foram registradas por um relógio comparador MITUTOYO ${ }^{\circledR}$ com precisão de $0,01 \mathrm{~mm}$, sendo as leituras realizadas a cada centésimo de milímetro. Uma pré-carga de $250 \mathrm{~g}$ foi aplicada para acomadação do sistema máquina, acessórios e espécime, sendo mantida por aproximadamente 60 segundos.

\subsubsection{Propriedades Analisadas:}

Com os valores obtidos das cargas e deformações de cada ensaio, foram confeccionados os gráficos (carga aplicada versus deformação), utilizando o programa de computador EXCEL ${ }^{\circledR}$. Nestes gráficos foram determinados os seguintes parâmetros: carga 
máxima, deformação máxima, energia absorvida pelo material até o momento da ruptura e Rigidez.

As cargas e deformações máximas, foram os maiores valores obtidos de cada ensaio, antes que ocorresse a ruptura do ligamento.

A energia foi obtida pelo cálculo da área abaixo da curva, utilizando uma macro de cálculo de área desenvolvida para o EXCEL ${ }^{\circledR}$.

A rigidez foi calculada pela inclinação da curva dos gráficos carga versus deformação, na fase linear, por serem estes valores numericamente iguais.

\subsubsection{Análise Estatística:}

Para os valores de carga máxima, deformação máxima, energia e rigidez obtidos com o ensaio mecânico de tração, foi aplicado o Teste t de Student, para amostras pareadas, para o membro posterior esquerdo e direito. 


\section{RESULTADOS}

Dos 52 animais do grupo imobilizado, 18 morreram no decorrer do período de 6 semanas de imobilização, sem causa física aparente e 9 precisaram ser sacrificados devido aos ferimentos causados pelo gesso e que não regrediram com a colocação de algodão para proteção, restando então 25 animais.

Os gráficos de carga versus deformação, obtidos no ensaio mecânico de tração, pelos 10 animais do grupo de avaliação metodológica e pelos 25 animais imobilizados, se encontram em Anexo, os quais forneceram os dados para a análise destes resultados.

Em todos os animais avaliados a ruptura ligamentar ocorreu na inserção femural, através de avulsão ligamentar.

\subsection{RESULTADOS DAS PROPRIEDADES ANALISADAS PARA O GRUPO DE AVALIAÇão METODOLÓGICA}

\subsubsection{CARGA MÁXIMA}

As hipóteses testadas, de acordo com os dados da TABELA 1, foram:

H0: não existe diferença estatisticamente significativa entre os ligamentos cruzado anterior das pernas esquerdas e direitas, em relação à carga máxima.

H1: existe diferença estatisticamente significativa entre os ligamentos cruzado anterior das pernas esquerdas e direitas, em relação à carga máxima. 
TABELA 1- Valores de Carga Máxima apresentados pelo ligamento cruzado anterior, no ensaio mecânico de tração, para o grupo de avaliação metodológica.

\begin{tabular}{ccc}
\multicolumn{3}{c}{ Carga(N) } \\
\hline Animal & Esquerdo & Direito \\
\hline \hline 1 & 22,07 & 22,2 \\
2 & 20,73 & 24,42 \\
3 & 24,84 & 14,6 \\
4 & 25,6 & 27,36 \\
5 & 22,88 & 12 \\
6 & 21,68 & 22,22 \\
7 & 22,9 & 24,32 \\
8 & 19,91 & 20,11 \\
9 & 17,89 & 15,29 \\
10 & 20,97 & 21,87 \\
\hline
\end{tabular}

Foram obtidos os seguintes valores para a Média e o Desvio Padrão das Cargas Máximas (TABELA 2):

TABELA 2-Valores da Média e do Desvio Padrão, em relação à Carga Máxima, para o grupo de avaliação metodológica.

\begin{tabular}{cccc} 
& $\mathrm{N}$ & Média & Desvio Padrão \\
\hline Esquerdo & 10 & $21,95 \mathrm{~N}$ & $2,27 \mathrm{~N}$ \\
Direito & 10 & $20,44 \mathrm{~N}$ & $4,93 \mathrm{~N}$ \\
\hline
\end{tabular}

Para se testar as hipóteses, foi aplicado o Teste t de Student (Pareado), onde se encontrou que: $\mathrm{t}=0.88$, e está entre os valores Tabelados $(-2,26 ; 2,26)$; podendo se dizer então, que não há diferença estatisticamente significativa entre os ligamentos cruzado anterior das pernas esquerdas e direitas.

O diagrama de colunas (FIGURA 12) abaixo, apresenta os valores médios de Carga Máxima, para o grupo de avaliação metodológica, que segundo o Teste t de Student não apresentaram diferença. 


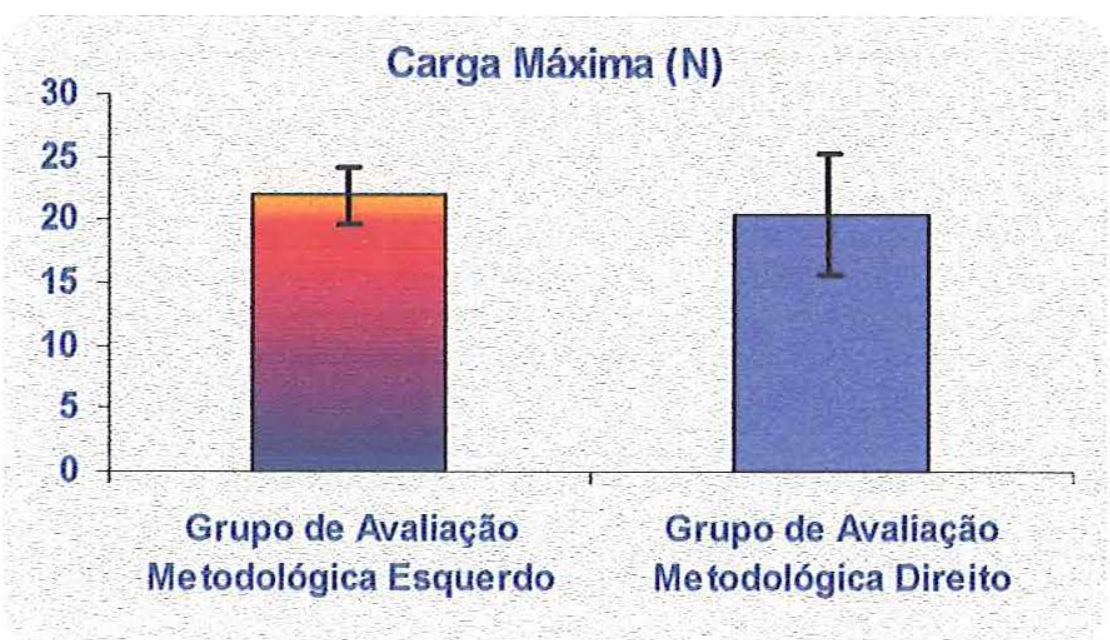

FIGURA 12-Diagrama de colunas com os valores de Média e Desvio Padrão para Carga Máxima, no grupo de avaliação metodológica.

\subsubsection{DEFORMAÇÃo MÁXIMA}

Na TABELA 3, se encontram os valores de Deformação Máxima, obtidos nos gráficos, para o grupo de avaliação metodológica.

TABELA 3 - Valores de Deformação Máxima, para o grupo de avaliação metodológica.

\begin{tabular}{|c|c|c|}
\hline \multicolumn{3}{|c|}{ Deformação $\left(\times 10^{-3} \mathrm{~m}\right)$} \\
\hline Animal & Esquerdo & Direito \\
\hline 1 & 0,2 & 0,21 \\
\hline 2 & 0,18 & 0,22 \\
\hline 3 & 0,27 & 0,15 \\
\hline 4 & 0,33 & 0,26 \\
\hline 5 & 0,26 & 0,16 \\
\hline 6 & 0,44 & 0,23 \\
\hline 7 & 0,22 & 0,2 \\
\hline 8 & 0,26 & 0,2 \\
\hline 9 & 0,18 & 0,18 \\
\hline 10 & 0,21 & 0,21 \\
\hline
\end{tabular}


Foram então, obtidos os seguintes valores para a Média e o Desvio Padrão (TABELA 4):

TABELA 4 - Valores da Média e do Desvio Padrão, em relação à Deformação Máxima, para o grupo de avaliação metodológica.

\begin{tabular}{cccc} 
& N & Média & Desvio Padrão \\
\hline Esquerdo & 10 & 0,255 & 0,08 \\
Direito & 10 & 0,202 & 0,01 \\
\hline
\end{tabular}

O Teste t de Student (Pareado) foi aplicado, e encontrou-se que: $\mathrm{t}=1.94$ e está entre os valores tabelados $(-2,26 ; 2,26)$. Pode-se dizer então, que não há diferença na deformação do ligamento cruzado anterior entre os lados esquerdos e direitos, com nível de significância de $5 \%$.

O diagrama de colunas (FIGURA 13) abaixo, apresenta os valores médios de Deformação Máxima, para o grupo de avaliação metodológica, que segundo o Teste t de Student não apresentaram diferença.

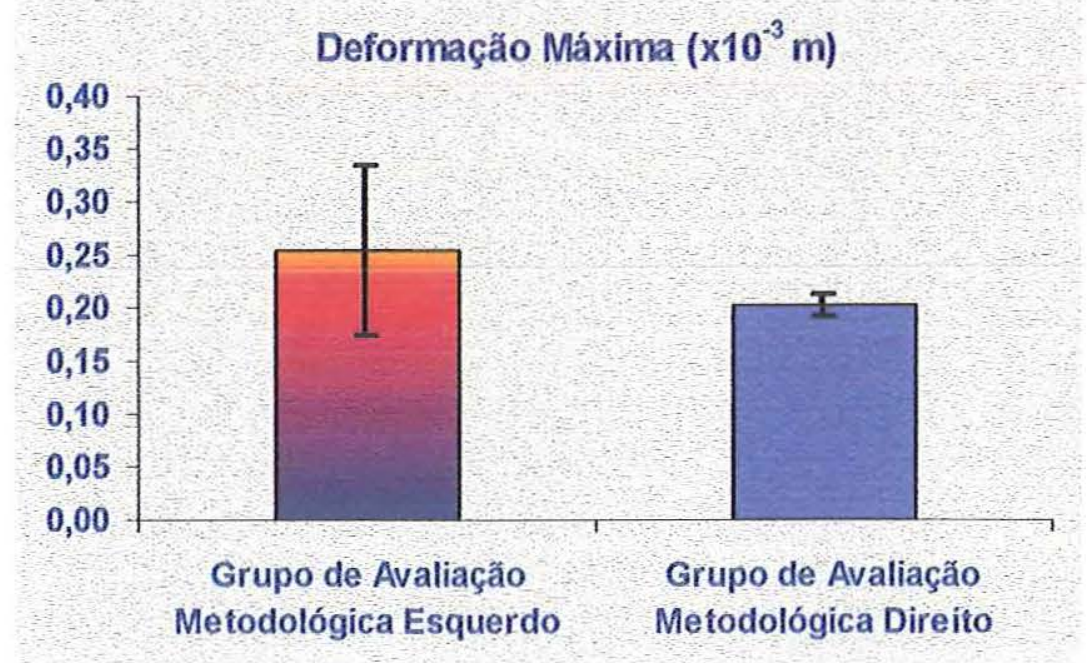

FIGURA 13-Diagrama de colunas com os valores de Média e Desvio Padrão para Deformação Máxima, no grupo de avaliação metodológica. 


\subsubsection{ENERgiA ABSORVIDA PELO LigAMENTO ATÉ O MOMENTO}

\section{DA RUPTURA.}

Os valores da área abaixo da curva, obtidos com uma macro de cálculo desenvolvida para o EXCEL ${ }^{\circledR}$, os quais foram transformados em energia se encontram no Apêndice 2.

De acordo com os dados das TABELAS 5 e 6, também foi aplicado o Teste $t$ de Student (Pareado), onde se encontrou que: $\mathrm{t}=1,96 \times 10^{-3}$ e está entre os valores tabelados ($2,26 ; 2,26)$. Portanto, no grupo de avaliação metodológica não há diferença na energia absorvida pelo ligamento cruzado anterior entre os lados esquerdos e direitos, com nível de significância de $5 \%$.

TABELA 5 - Valores de Energia, para o grupo de avaliação metodológica.

\section{Energia (J)}

\begin{tabular}{ccc}
\hline Animal & Esquerdo & Direito \\
\hline \hline 1 & $2,896 \times 10^{-3}$ & $2,612 \times 10^{-3}$ \\
2 & $3,185 \times 10^{-3}$ & $3,440 \times 10^{-3}$ \\
3 & $3,107 \times 10^{-3}$ & $1,380 \times 10^{-3}$ \\
4 & $4,165 \times 10^{-3}$ & $3,850 \times 10^{-3}$ \\
5 & $3,492 \times 10^{-3}$ & $1,112 \times 10^{-3}$ \\
6 & $3,969 \times 10^{-3}$ & $2,922 \times 10^{-3}$ \\
7 & $2,743 \times 10^{-3}$ & $3,133 \times 10^{-3}$ \\
8 & $3,334 \times 10^{-3}$ & $2,642 \times 10^{-3}$ \\
9 & $1,835 \times 10^{-3}$ & $1,850 \times 10^{-3}$ \\
10 & $2,843 \times 10^{-3}$ & $2,888 \times 10^{-3}$ \\
\hline
\end{tabular}

TABELA 6- Valores da Média e do Desvio Padrão, em relação à Energia, para o grupo de avaliação metodológica.

\begin{tabular}{lccc}
\hline & $\mathrm{N}$ & Média & Desvio Padrão \\
\hline Esquerdo & 10 & $3,187 \times 10^{-3}$ & $6,24 \times 10^{-4}$ \\
\hline Direito & 10 & $2,583 \times 10^{-3}$ & $8,36 \times 10^{-4}$ \\
\hline \hline
\end{tabular}


O diagrama de colunas (FIGURA 14) abaixo, apresenta os valores médios de Energia para o grupo de avaliação metodológica, que segundo o Teste t de Student não apresentaram diferença.

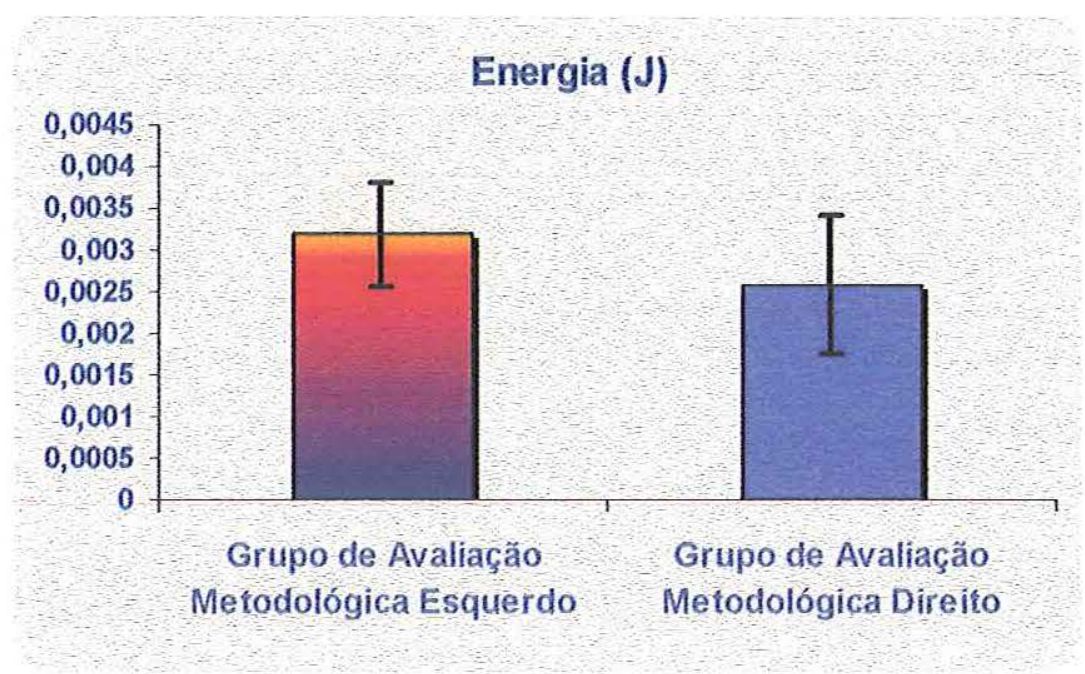

FIGURA 14-Diagrama de colunas com os valores de Média e Desvio Padrão para Energia, no grupo de avaliação metodológica.

\subsubsection{RIGIDEZ}

Por serem a inclinação das curvas numericamente iguais a rigidez, estes valores foram calculados e se encontram na Tabela 7 .

TABELA 7-Valores de Rigidez apresentados pelo ligamento cruzado anterior, no ensaio mecânico de tração, para o grupo de avaliação metodológica.

\begin{tabular}{ccc}
\multicolumn{3}{c}{ Rigidez (N/m) } \\
\hline Animal & Esquerdo & Direito \\
\hline \hline 1 & 112,7 & 99,33 \\
2 & 99,55 & 108,25 \\
3 & 83,86 & 79,34 \\
4 & 52,05 & 94,31 \\
5 & 88,25 & 85,46 \\
6 & 66,13 & 84,97 \\
7 & 89,75 & 107,4 \\
8 & 82,62 & 101,08 \\
9 & 81,61 & 76,96 \\
10 & 102,6 & 108,35 \\
\hline
\end{tabular}


Foram obtidos os seguintes valores para a Média e o Desvio Padrão da Rigidez (TABELA 8):

TABELA 8-Valores da Média e do Desvio Padrão, em relação à Rigidez, para o grupo de avaliação metodológica

\begin{tabular}{lccc}
\hline & $\mathbf{N}$ & Média & Desvio Padrão \\
\hline \hline Esquerdo & 10 & 85,91 & 16,65 \\
Direito & 10 & 94,54 & 11,51 \\
\hline
\end{tabular}

Com os dados da TABELA 7 e 8, no Teste t de Student (Pareado), encontrou-se que: $t=0,21$, e está entre os valores tabelados $(-2,26 ; 2,26)$; podendo se dizer então que não há diferença estatisticamente significativa entre os ligamentos cruzado anterior das pernas esquerdas e direitas, em relação a rigidez, com nível de significância de $5 \%$.

O diagrama de colunas (FIGURA 15) abaixo, apresenta os valores médios de Rigidez para o grupo de avaliação metodológica, que segundo o Teste t de Student não apresentaram diferença.

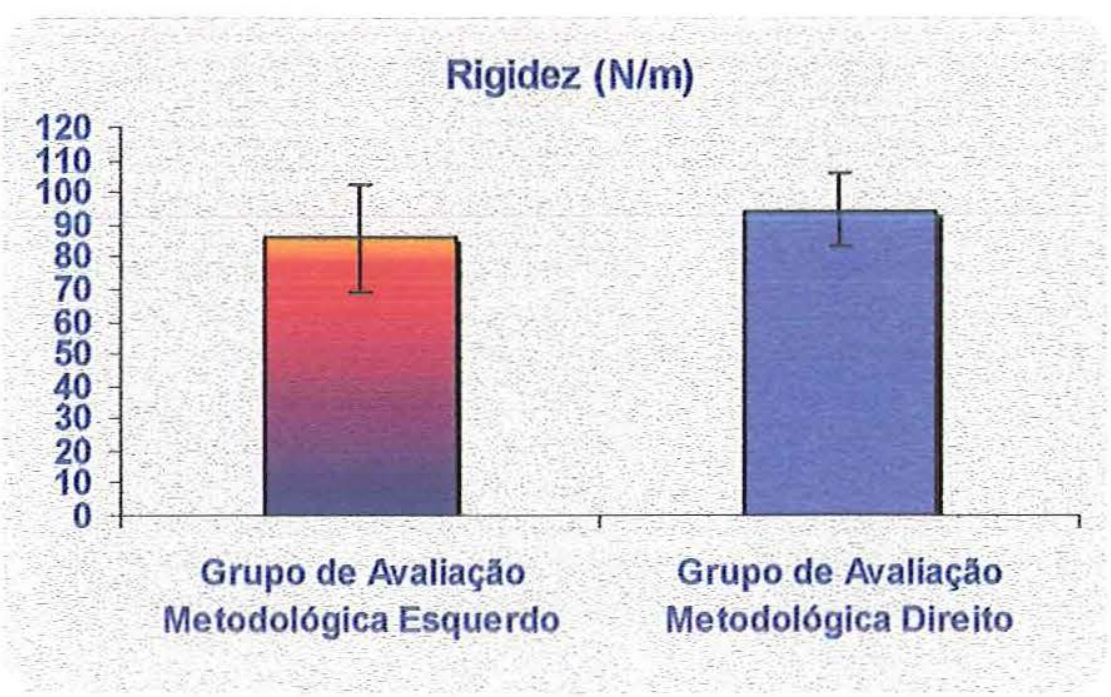

FIGURA 15-Diagrama de colunas com os valores de Média e Desvio Padrão para Rigidez, no grupo de avaliação metodológica. 


\subsection{RESULTADOS DAS PROPRIEDADES ANALISADAS NO GRUPO IMOBILIZADO}

Neste grupo as propriedades analisadas e hipóteses testadas, foram as mesmas usadas para o grupo de avaliação metodológica.

\subsubsection{CARGA MÁXIMA}

Os dados obtidos para o grupo imobilizado estão apresentados na TABELA 9.

TABELA 9 - Valores de Carga Máxima, para o grupo imobilizado.

\begin{tabular}{ccc}
\multicolumn{3}{c}{ Carga(N) } \\
\hline Animal & $\begin{array}{c}\text { Esquerdo } \\
\text { (imobilizado) }\end{array}$ & $\begin{array}{c}\text { Direito } \\
\text { (controle) }\end{array}$ \\
\hline \hline 1 & 21,51 & 22,07 \\
3 & 29,08 & 23,29 \\
4 & 21,12 & 17,12 \\
5 & 29,65 & 24,27 \\
6 & 20,55 & 17,59 \\
8 & 28,05 & 26,28 \\
9 & 26,31 & 23,69 \\
11 & 25,4 & 27,02 \\
12 & 24,76 & 26,68 \\
13 & 29,3 & 25,06 \\
15 & 19,67 & 29,47 \\
17 & 36,23 & 22,95 \\
19 & 30,99 & 30,02 \\
21 & 19,77 & 29,99 \\
22 & 28,96 & 28,47 \\
23 & 22,93 & 26,04 \\
24 & 30,18 & 31,13 \\
25 & 24,7 & 28,32 \\
26 & 23,23 & 23,54 \\
27 & 31,28 & 31,51 \\
29 & 30,15 & 26,33 \\
32 & 26,09 & 25,38 \\
37 & 25,74 & 21,81 \\
38 & 26,26 & 41,62 \\
40 & 24,55 & 28,22 \\
\hline
\end{tabular}

Foram obtidos os seguintes valores para a Média e o Desvio Padrão (TABELA 10): 
TABELA 10 - Valores da Média e do Desvio Padrão, em relação à Carga Máxima, para o grupo imobilizado.

\begin{tabular}{lccc}
\hline & N & Média & Desvio Padrăo \\
\hline \hline Esquerdo-imobilizado & 25 & $26,25 \mathrm{~N}$ & $4,14 \mathrm{~N}$ \\
Direito-controle & 25 & $26,37 \mathrm{~N}$ & $4,95 \mathrm{~N}$ \\
\hline
\end{tabular}

Foi aplicado também o Teste t de Student (Pareado), para se testar as hipótese, sendo $\mathrm{t}=-0.09$, que está entre os valores tabelados $(-2,06 ; 2,06) ;$ o que indica que no grupo imobilizado também não houve diferença estatisticamente significativa entre os ligamentos cruzado anterior das pernas esquerdas e direitas.

No diagrama de colunas (FIGURA 16) abaixo, o qual apresenta os valores médios de Carga Máxima, para o grupo imobilizado, é possível se constatar que neste grupo também não houve diferença.

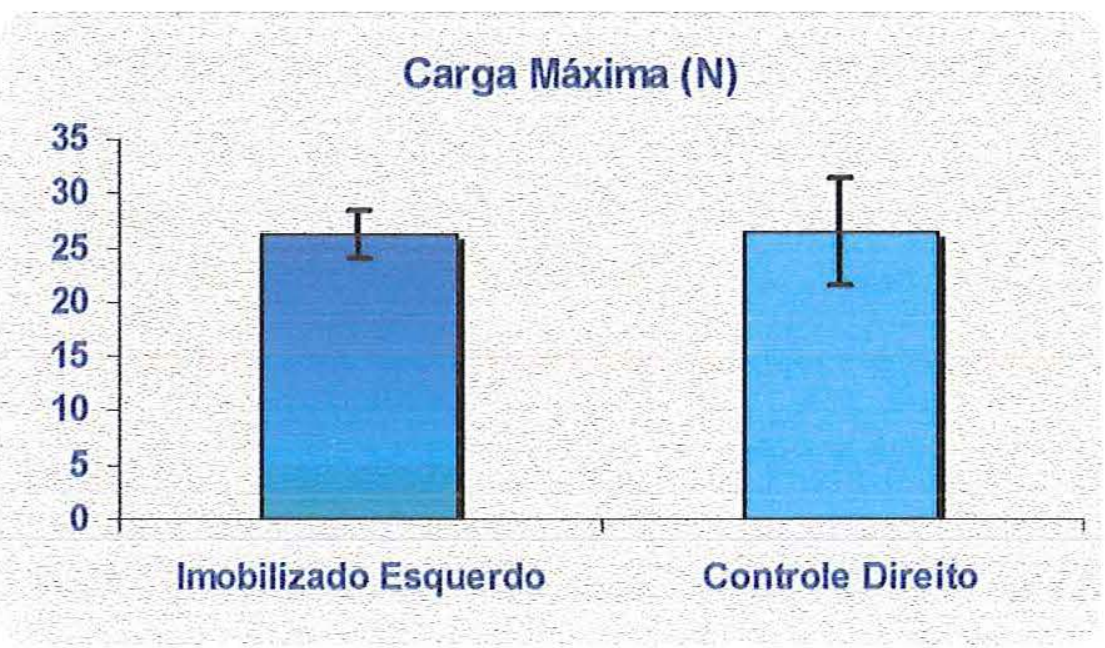

FIGURA 16-Diagrama de colunas com os valores de Média e Desvio Padrão para Carga Máxima, no grupo imobilizado.

\subsubsection{DEFORMAÇÃO MÁXIMA}

Neste grupo de acordo com os valores das TABELAS 11 e 12, no Teste t de Student (Pareado), obteve-se $t=0.38$, e está entre os valores tabelados $(-2,06 ; 2,06)$. Pode se dizer então, que no grupo imobilizado também não houve diferença entre as pernas esquerdas e direitas, com nível de significância de $5 \%$. 
TABELA 11- Valores de Deformação Máxima, para o grupo imobilizado.

\begin{tabular}{ccc}
\multicolumn{3}{c}{ Deformação(x10-3 $\mathrm{m}$ ) } \\
\hline Animal & $\begin{array}{c}\text { Esquerdo } \\
\text { (imobilizado) }\end{array}$ & $\begin{array}{c}\text { Direito } \\
\text { (controle) }\end{array}$ \\
\hline \hline 1 & 0,18 & 0,18 \\
3 & 0,21 & 0,18 \\
4 & 0,14 & 0,14 \\
5 & 0,25 & 0,21 \\
6 & 0,15 & 0,21 \\
8 & 0,22 & 0,15 \\
9 & 0,2 & 0,24 \\
11 & 0,26 & 0,21 \\
12 & 0,21 & 0,24 \\
13 & 0,23 & 0,23 \\
15 & 0,21 & 0,22 \\
17 & 0,29 & 0,24 \\
19 & 0,25 & 0,23 \\
21 & 0,11 & 0,2 \\
22 & 0,28 & 0,18 \\
23 & 0,19 & 0,19 \\
24 & 0,28 & 0,29 \\
25 & 0,23 & 0,24 \\
26 & 0,25 & 0,19 \\
27 & 0,29 & 0,31 \\
29 & 0,18 & 0,21 \\
32 & 0,25 & 0,15 \\
37 & 0,25 & 0,15 \\
38 & 0,18 & 0,26 \\
40 & 0,19 & 0,19 \\
\hline
\end{tabular}

TABELA 12- Valores de Média e Desvio Padrão, em relação à Deformação Máxima, para o grupo imobilizado.

\begin{tabular}{lccc}
\hline & $\mathrm{N}$ & Média & Desvio Padråo \\
\hline Esquerdo-imobilizado & 25 & 0,216 & 0,047 \\
Direito-controle & 25 & 0,211 & 0,008 \\
\hline
\end{tabular}

No diagrama de colunas abaixo (FIGURA 17), o qual apresenta os valores médios de deformação máxima, para o grupo imobilizado, pode se constatar os resultados do Teste t de Student. 


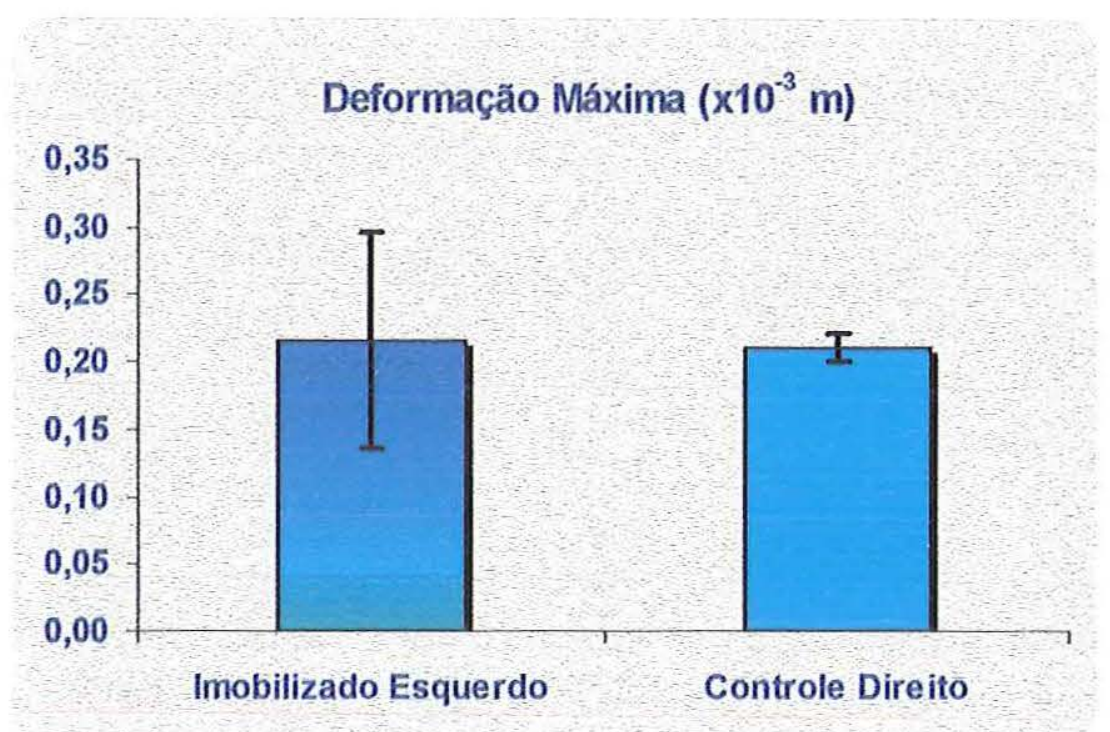

FIGURA 17 - Diagrama de colunas com os valores de Média e Desvio Padrão para Deformação Máxima, no grupo imobilizado

\subsubsection{ENERgia ABSORVIDA PElo ligAmento ATÉ o mOMENTO DA RUPTURA}

Neste grupo com os valores das TABELAS 13 e 14, quando aplicado o Teste t. de Student (Pareado), encontrou-se que $t=3,43 \times 10^{-6}$, estando entre os valores tabelados $(-2,06$, 2,06). Indicando, que no grupo imobilizado, também não houve diferença entre as pernas esquerdas e direitas, em relação à energia, com nível de significância de $5 \%$. 
TABELA 13- Valores de Energia Absorvida para o grupo imobilizado.

Energia (J)

\begin{tabular}{ccc}
\hline Animal & $\begin{array}{c}\text { Esquerdo } \\
\text { (imobilizado) }\end{array}$ & $\begin{array}{c}\text { Direito } \\
\text { (controle }\end{array}$ \\
\hline \hline 1 & $2,610 \times 10^{-3}$ & $2,701 \times 10^{-3}$ \\
3 & $3,643 \times 10^{-3}$ & $2,712 \times 10^{-3}$ \\
4 & $1,832 \times 10^{-3}$ & $1,695 \times 10^{-3}$ \\
5 & $4,498 \times 10^{-3}$ & $3,228 \times 10^{-3}$ \\
6 & $3,252 \times 10^{-3}$ & $2,590 \times 10^{-3}$ \\
8 & $3,678 \times 10^{-3}$ & $2,403 \times 10^{-3}$ \\
9 & $3,557 \times 10^{-3}$ & $3,402 \times 10^{-3}$ \\
11 & $3,474 \times 10^{-3}$ & $4,981 \times 10^{-3}$ \\
12 & $3,289 \times 10^{-3}$ & $3,610 \times 10^{-3}$ \\
13 & $4,152 \times 10^{-3}$ & $3,506 \times 10^{-3}$ \\
15 & $2,131 \times 10^{-3}$ & $3,522 \times 10^{-3}$ \\
17 & $5,583 \times 10^{-3}$ & $3,603 \times 10^{-3}$ \\
19 & $5,116 \times 10^{-3}$ & $3,653 \times 10^{-3}$ \\
21 & $1,351 \times 10^{-3}$ & $3,525 \times 10^{-3}$ \\
22 & $4,922 \times 10^{-3}$ & $3,015 \times 10^{-3}$ \\
23 & $2,956 \times 10^{-3}$ & $2,658 \times 10^{-3}$ \\
24 & $4,668 \times 10^{-3}$ & $4,765 \times 10^{-3}$ \\
25 & $3,693 \times 10^{-3}$ & $3,682 \times 10^{-3}$ \\
26 & $3,654 \times 10^{-3}$ & $3,148 \times 10^{-3}$ \\
27 & $5,137 \times 10^{-3}$ & $6,116 \times 10^{-3}$ \\
29 & $3,269 \times 10^{-3}$ & $3,096 \times 10^{-3}$ \\
32 & $4,058 \times 10^{-3}$ & $3,017 \times 10^{-3}$ \\
37 & $2,934 \times 10^{-3}$ & $2,719 \times 10^{-3}$ \\
38 & $2,646 \times 10^{-3}$ & $5,917 \times 10^{-3}$ \\
40 & $2,862 \times 10^{-3}$ & $3,516 \times 10^{-3}$ \\
\hline & &
\end{tabular}

TABELA 14- Valores de Média e Desvio Padrão, em relação à Energia Absorvida, para o grupo imobilizado

\begin{tabular}{lccc}
\hline & $\mathbf{N}$ & Média & Desvio Padrão \\
\hline Esquerdo(imobilizado) & 25 & $3,516 \times 10^{-3}$ & $1,034 \times 10^{-3}$ \\
Direito(controle) & 25 & $3,471 \times 10^{-3}$ & $1,004 \times 10^{-3}$ \\
\hline
\end{tabular}

No diagrama de colunas abaixo (FIGURA 18), o qual apresenta valores médios de Energia, para o grupo imobilizado, pode se constatar os resultados do Teste t de Student. 


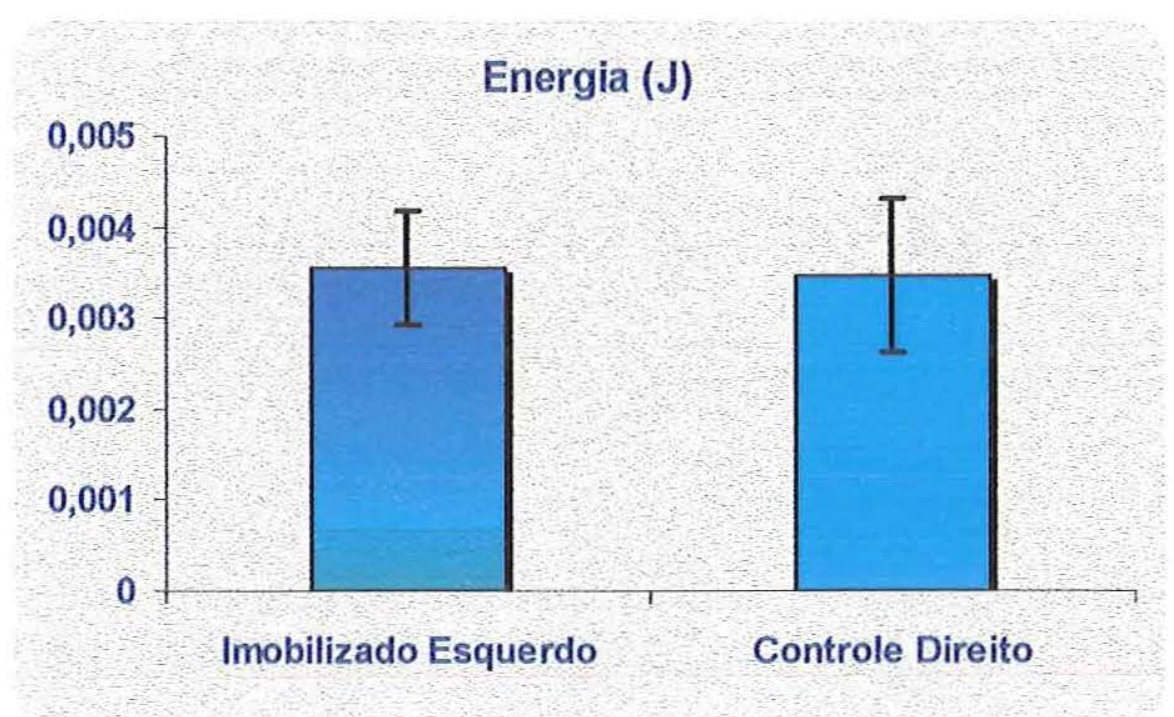

FIGURA 18 - Diagrama de colunas com os valores de Média e Desvio Padrão para Energia, no grupo imobilizado.

\subsubsection{RIGIDEZ}

Os valores de Rigidez,, os quais, também foram calculados pela inclinação das curvas apresentadas pelos gráficos, como no grupo de avaliação metodológica, se encontram na TABELA 15. 
TABELA 15- Valores de Rigidez, para o grupo imobilizado.

\begin{tabular}{ccc}
\multicolumn{3}{c}{ Rigidez (N/m) } \\
\hline Animal & $\begin{array}{c}\text { Esquerdo } \\
\text { (imobilizado) }\end{array}$ & $\begin{array}{c}\text { Direito } \\
\text { (controle) }\end{array}$ \\
\hline \hline 1 & 102,65 & 112,45 \\
3 & 104,55 & 153,54 \\
4 & 158,73 & 109,06 \\
5 & 75,81 & 114,66 \\
6 & 91,63 & 85,43 \\
8 & 146,74 & 105,41 \\
9 & 85,56 & 128,6 \\
11 & 121,3 & 103,53 \\
12 & 119,52 & 114,14 \\
13 & 144,99 & 148,43 \\
15 & 144,93 & 138,24 \\
17 & 124,85 & 162,34 \\
19 & 159,61 & 143,69 \\
21 & 100,49 & 156,56 \\
22 & 145,09 & 152,72 \\
23 & 135,06 & 149,61 \\
24 & 131,38 & 131,5 \\
25 & 110,4 & 142,23 \\
26 & 122,63 & 98,74 \\
27 & 112,86 & 114,19 \\
29 & 155,28 & 100,63 \\
32 & 130,59 & 137,39 \\
37 & 118,02 & 162,75 \\
38 & 124,8 & 155,59 \\
40 & 144,02 & 118,8 \\
\hline & &
\end{tabular}

Foram obtidos os seguintes valores para a Média e o Desvio Padrão (TABELA 16):

TABELA 16- Valores da Média e do Desvio Padrão, em relação à Rigidez.

\begin{tabular}{lccc} 
& N & Média & Desvio Padrão \\
\hline Esquerdo(imob.) & 25 & 124,46 & 22,38 \\
Direito(controle) & 25 & 129,61 & 22,34 \\
\hline
\end{tabular}

Neste grupo de acordo com os dados das TABELAS 15 e 16, também foi aplicado o Teste t de Student (Pareado); onde se encontrou que: $\mathrm{t}=0,42$, e está entre os valores 
tabelados $(-2,06 ; 2,06)$; portanto não existe diferença estatisticamente significativa entre os ligamentos cruzado anterior das pernas esquerdas e direitas, com nível de significância de $5 \%$.

No diagrama de colunas abaixo (FIGURA 19), o qual apresenta valores médios de Rigidez para o grupo imobilizado, pode se observar que também não houve diferença.

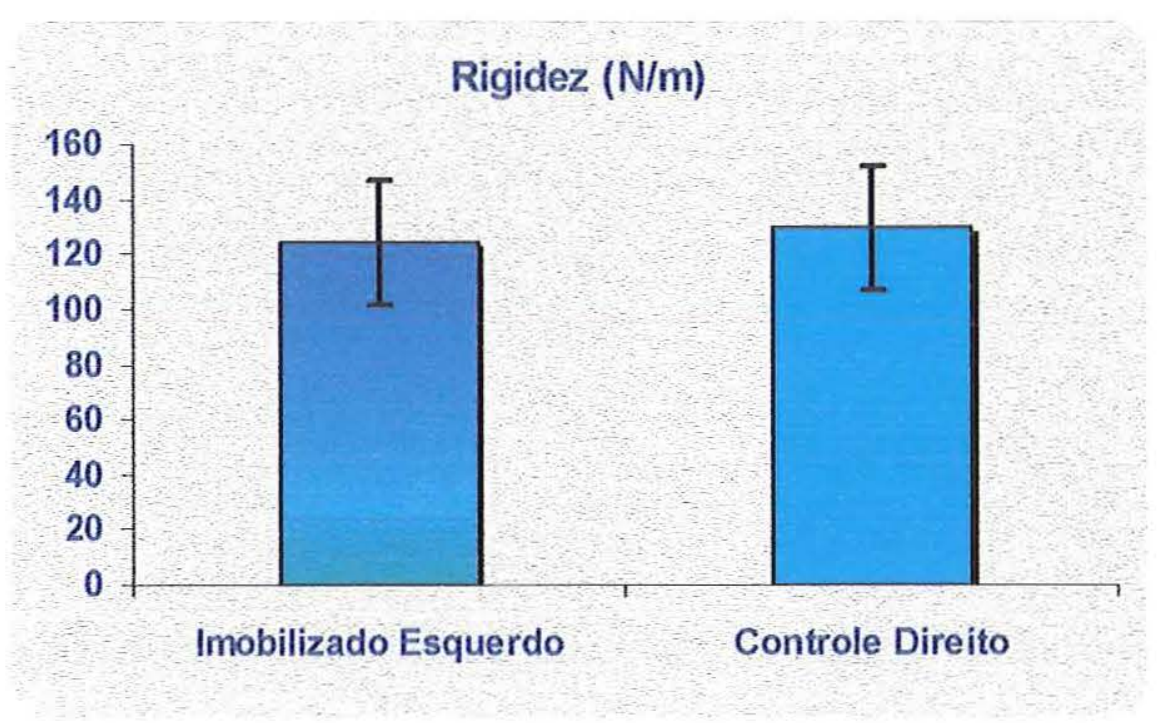

FIGURA 19 - Diagrama de colunas com os valores de Média e Desvio Padrão para Rigidez, no grupo imobilizado. 


\section{DISCUSSÃO}

Antes de entrar na discussão propriamente dita, gostaria de enfatizar que a idéia inicial deste trabalho era, além de verificar a presença de alteração na resistência do ligamento cruzado anterior após 6 semanas de imobilização gessada, observar como esta resistência se comportava após períodos diferentes de remobilização (1 mês, 3 meses e 6 meses), com exercícios ativos livres, o que poderia trazer informações bastante importantes para a prática clínica, já que na nossa rotina de trabalho nos deparamos constantemente com pacientes que passaram por períodos de imobilização. Poucos foram os trabalhos consultados, que enfatizavam em seus objetivos e conclusões o tempo necessário para que este ligamento retornasse à sua capacidade de suporte de carga, a qual este apresentava antes do período de imobilização. Em outras palavras, como se processava a recuperação da resistência deste ligamento (EVANS et al, 1960; NOYES et al 1974; AKESON et al, 1987;WOO et al, 1987; WOO et al, 1994 ).

Segundo NOYES (1977); WOO et al (1994); AKESON (1987), os efeitos da imobilização na resistência do ligamento cruzado anterior podem ser observados com períodos de imobilização de semanas, no entanto, para o retorno à condição inicial, foram necessários 12 meses.

Quando o ensaio mecânico de tração foi realizado nos 6 primeiros animais, não foi encontrada diferença na resistência do ligamento cruzado anterior, no membro posterior imobilizado em relação ao controle. Diante deste fato que contraria a literatura e a lógica, 
foram imobilizados mais 30 animais, para que se tivesse uma amostra maior, e com isso se ter maior segurança em traçar conclusões. Após o período de 6 semanas de imobilização, restaram 19 animais, os quais tiveram seus dados analisados juntamente, com os 6 animais avaliados anteriormente, mas que, apesar da maior amostragem, não foi observado diferença do membro imobilizado em relação ao membro controle, no que diz respeito à resistência do ligamento cruzado anterior. Foi então descartado o objetivo inicial de verificar o comportamento deste ligamento com períodos diferentes de remobilização. Alguns fatores podem ter contribuído para que os dados obtidos neste trabalho não coincidam com a literatura, os quais serão comentados no decorrer desta discussão.

Dos trabalhos consultados somente TIPTON et al, (1967a) e NOYES et al (1974) utilizaram atadura gessada para imobilização e não comentam sobre eventuais difículdades em manter estes animais imobilizados. O uso de fixação interna e externa e tenotomia muscular foram os procedimentos mais utilizados (EVANS et al (1960); TIPTON et al (1967a); AKESON et al (1973); AMIEL et al (1983); BINKLEY \& PEAT (1986); WOO et al (1987); PADGETT \& DAHNERS (1992).

EVANS et al (1960), comentam que a fixação interna, foi escolhida para iimobilização, após várias tentativas com outros métodos, inclusive o gesso. Como na nossa rotina de trabalho nos deparamos em maior proporção com imobilizações gessadas, este método foi escolhido para a imobilização da articulação do joelho.

A imobilização gessada não é uma imobilização rígida, com isso permite uma porcentagem de movimento na articulação, que com a imobilização através de fixação interna não ocorre.

Segundo WOO et al (1994), tecidos biológicos com dimensões pequenas são de dificil fixação à Máquina de Ensaio devido escorregamento na garra, e quando a fixação se torna possivel, pode ocorrer a concentração de stress nos pontos de fixação. Estas 
dificuldades foram encontradas, e também associada a abertura na placa de crescimento quando se tentou reproduzir a metodologia descrita por TIPTON et al (1967b).

Estes autores referem a ocorrência de abertura da placa de crescimento antes da ruptura ligamentar, mas sem mencionar a incidência, nem de que forma solucionaram este problema. Neste trabalho este fator impediu a reprodução do método, se fazendo necessário o desenvolvimento de outra metodologia, que além de eliminar o problema da abertura da placa de crescimento, difere dos trabalhos consultados nos quais a tração era realizada não na interlinha articular, mas com suas garras posicionadas mais distalmente, sendo a tração não somente na junção osso-ligamento-osso, mas em uma quantidade maior de tecido ósseo. Consequentemente os resultados deste trabalho eliminam a análise de parte de tecido ósseo que deixou de ser tracionado, sendo a carga aplicada somente na junção osso-ligamentoosso, o que provavelmente está relacionado aos nossos resultados obtidos.

Outras condições diferem da literatura consultada, como por exemplo, a utilização de ratos da linhagem Wistar, por serem estes animais, de fácil disponibilidade pelo Biotério Central da Faculdade de Medicina de Ribeirão Preto, pela semelhança da articulação do joelho com esta articulação em humanos e por serem estes animais facilmente mantidos num pequeno espaço físico. Nos trabalhos consultados, os animais utilizados foram coelhos, ratos da linhagem Sprague Dawley e cachorros, e o trabalho de NOYES et al (1974) fez uso de macacos.

Devido à grande incidência de lesões que acometem o ligamento cruzado anterior e por suas implicações clínicas, este ligamento foi escolhido para este trabalho. O ligamento mais utilizado pela literatura para se verificar os efeitos da imobilização foi o ligamento colateral medial, pelo seu acesso fácil.

Segundo TIPTON et al (1967b), testando a resistência do ligamento colateral medial em posições que variam de 0 à 90 graus de flexão, não houve diferença estatisticamente significativa. Por isso foi utilizado neste trabalho uma flexão de 90 graus, 
por esta posição se adaptar melhor ao dispositivo desenvolvido, embora se entenda que a complexidade anatômica do ligamento cruzado anterior se diferencie bastante do ligamento colateral medial, mas segundo KAPANJI (1987), a direção de inclinação das fibras do ligamento cruzado anterior quando em posição de flexão de 90 graus ou de extensão se encontram pouco alteradas, apresentando somente alteração de tensão nos seus diferentes feixes, já o ligamento cruzado posterior que em extensão apresenta posição mais horizontal, quando em flexão máxima, levanta-se verticalmente, descrevendo arco de círculo de mais de 60 graus em relação à tíbia.

Segundo WOO et al (1994), fatores experimentais como temperatura, estado de hidratação e principalmente a orientação do espécime, podem alterar o comportamento mecânico do ligamento, e que o ligamento cruzado anterior em particular por apresentar fibras de comprimentos diferentes unidas e inseridas numa complexa geometria, apresentou diminuição na carga suportada, quando esta não era aplicada respeitando a orientação anatômica, mas na orientação tibial, ou seja o ligamento era mantido ao longo do eixo tibial, permitindo um deslocamento femural interno. Neste trabalho a orientação anatômica foi mantida.

De acordo com TIPTON et al (1967a), a velocidade de tração imposta pela Máquina de Ensaio Universal pode variar de 0,01 à $0,50 \mathrm{~mm} / \mathrm{seg}$, sem que este fator comprometa os resultados. Neste trabalho foi utilizado uma velocidade de $0,25 \mathrm{~mm} / \mathrm{seg}$. Então, embora outros trabalhos utilizem posições e velocidades diferentes, estes fatores estão descartados como tendo interferido nos resultados.

Em todos os animais testados a ruptura ligamentar ocorreu em nível da sua inserção femural, através de avulsão ligamentar, o que coincide com a literatura consultada. WOO et al (1994), comentam que, em laboratório, dificilmente a ruptura irá ocorrer na substância ligamentar, mas sim será encontrada uma avulsão no ponto de inserção ligamentar, por ser este o ponto de maior fraqueza.

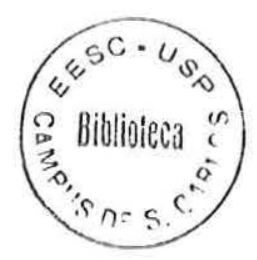


Um fato observado foi que o ganho de peso dos animais (Apêndice 1) no grupo imobilizado após o período de 6 semanas de imobilização, não foi significativo, provavelmente devido ao stress sofrido por estes animais. Segundo TIPTON et al (1978), o peso está relacionado à resistência ligamentar, assim como o sexo e a idade.

Devido as dimensões do ligamento cruzado anterior dos animais utilizados neste trabalho, não foi possível se detectar a área de seç̧ão transversal, obtendo-se um gráfico de carga versus deformação onde as propriedades estruturais e não mecânicas foram analisadas.

Quando se tentou realizar a análise das propriedades estruturais na fase elástica, houve grande dificuldade em se determinar o limite de proporcionalidade, o que provavelmente se deva a desigualdade no comprimento das fibras do ligamento cruzado anterior pois segundo KAPANJI (1987), elas variam $\mathrm{cm}$ humanos de 1,85 à $3,35 \mathrm{~cm}$, onde o feixe antero-interno é mais longo e o mais exposto aos traumatismos, o feixe póstero-externo é o que mais resiste nas rupturas parciais e existe também um feixe intermediário. Para se evitar falsas interpretações, a análise das propriedades estruturais específica da fase elástica foi descartada.

A análise macroscópica da articulação não era objetivo deste trabalho, mas a proliferação de tecido adiposo, rigidez articular, presença de aderências e atrofia muscular intensa foram observadas nos membros imobilizados, o que nos indica, que houveram alterações devidas à imobilização, mas que, talvez o período de 6 semanas, com imobilização gessada, não foram suficientes para se detectar alterações na resistência mecânica do ligamento cruzado anterior, principalmente se utilizando de uma metodologia no ensaio mecânico de tração, a qual somente a junção osso-ligamento-osso foi testada.

Acreditamos porém que a diferença nos resultados, provavelmente esteja relacionada com o método utilizado para imobilização e também com a metodologia empregada na fixação do espécime à Maquina de Ensaio Universal, e que talvez seja 
necessário um tempo maior de imobilização gessada para se encontrar os mesmos resultados obtidos com 6 semanas de imobilização com fixação interna. 


\section{CONCLUSÕES}

1. Não houve diferença na resistência do ligamento cruzado anterior, no membro posterior imobilizado com atadura gessada, por 6 semanas em relação ao membro contralateral (controle).

2. A metodologia empregada para a fixação do espécime à Máquina de Ensaio Universal, que diferentemente da literatura aplica a tração mais diretamente no ligamento e na junção osteo-ligamentar, provavelmente esteja relacionada aos resultados. 
ANEXO

\section{GRUPO CONTROLE-Animal 01}

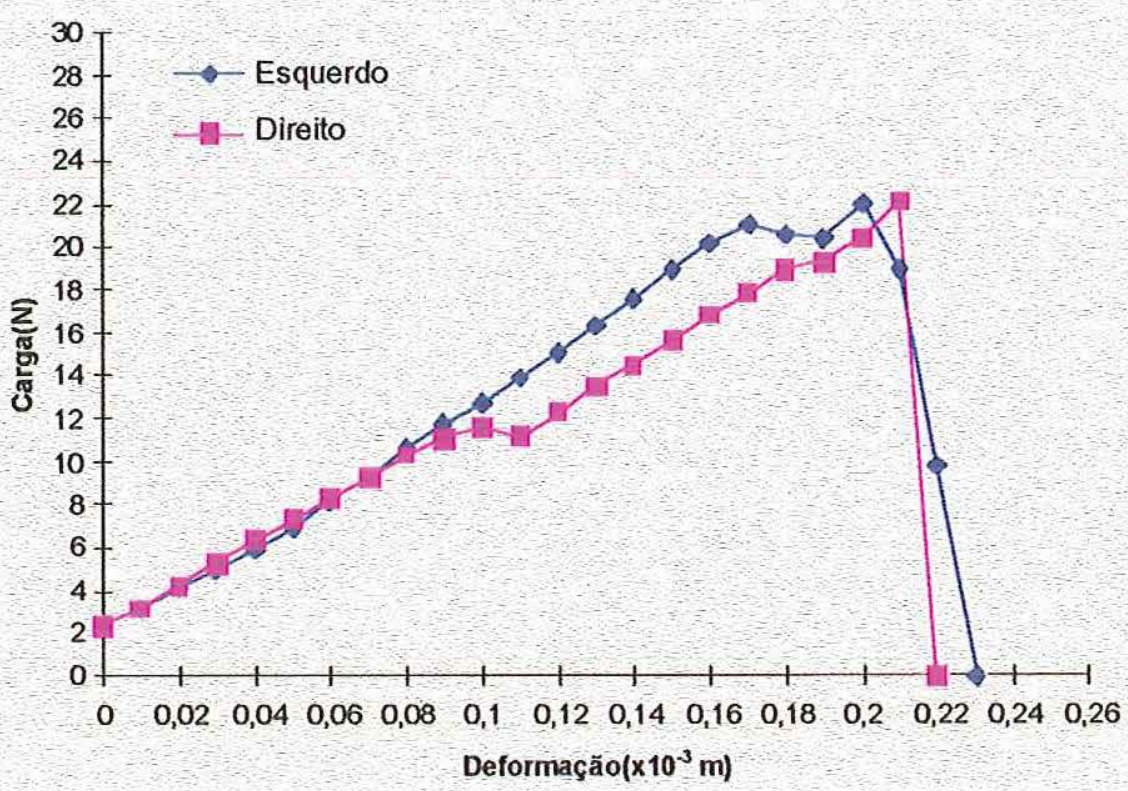

GRUPO CONTROLE-Animal 02

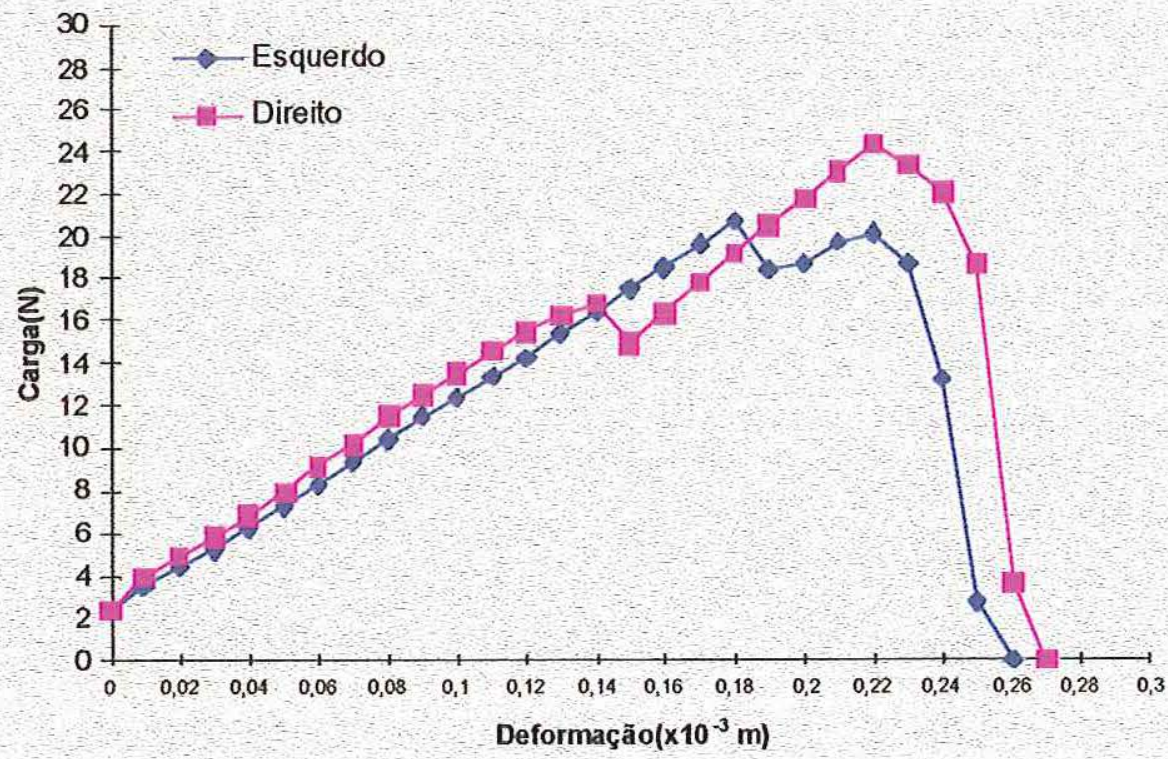


GRUPO CONTROLE-Animal 03

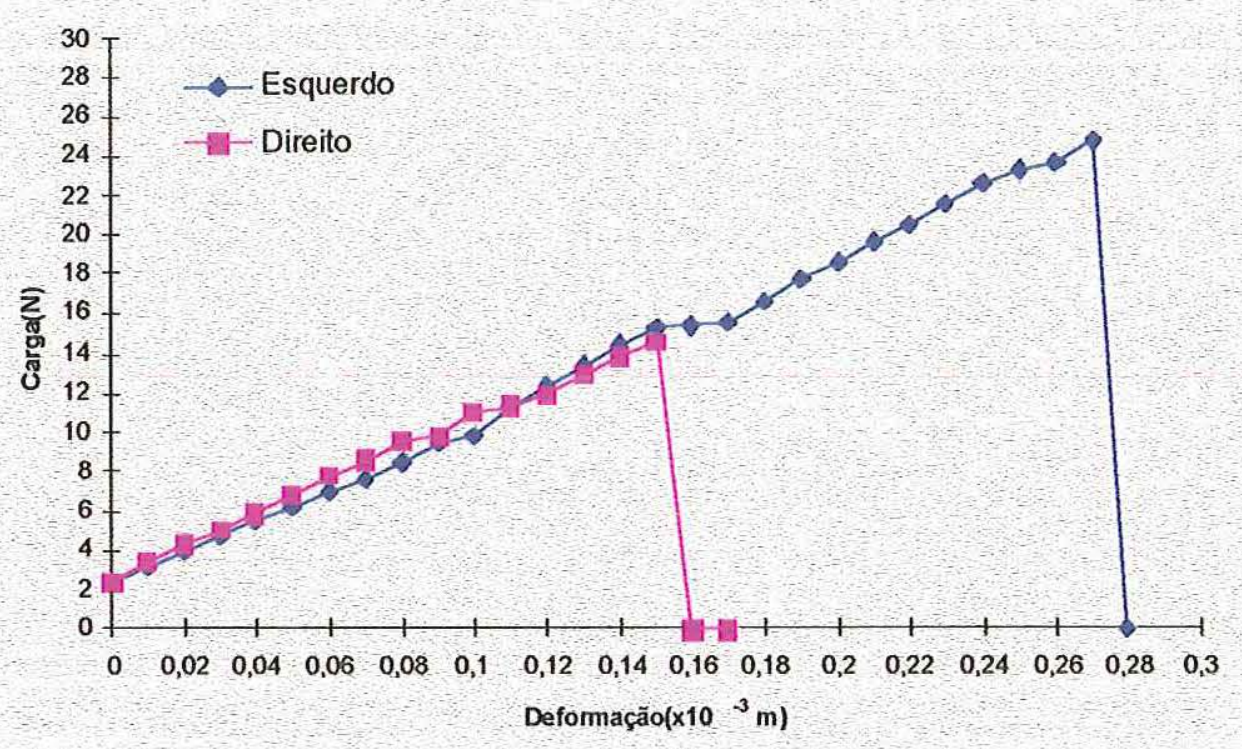

GRUPO CONTROLE- Animal 04

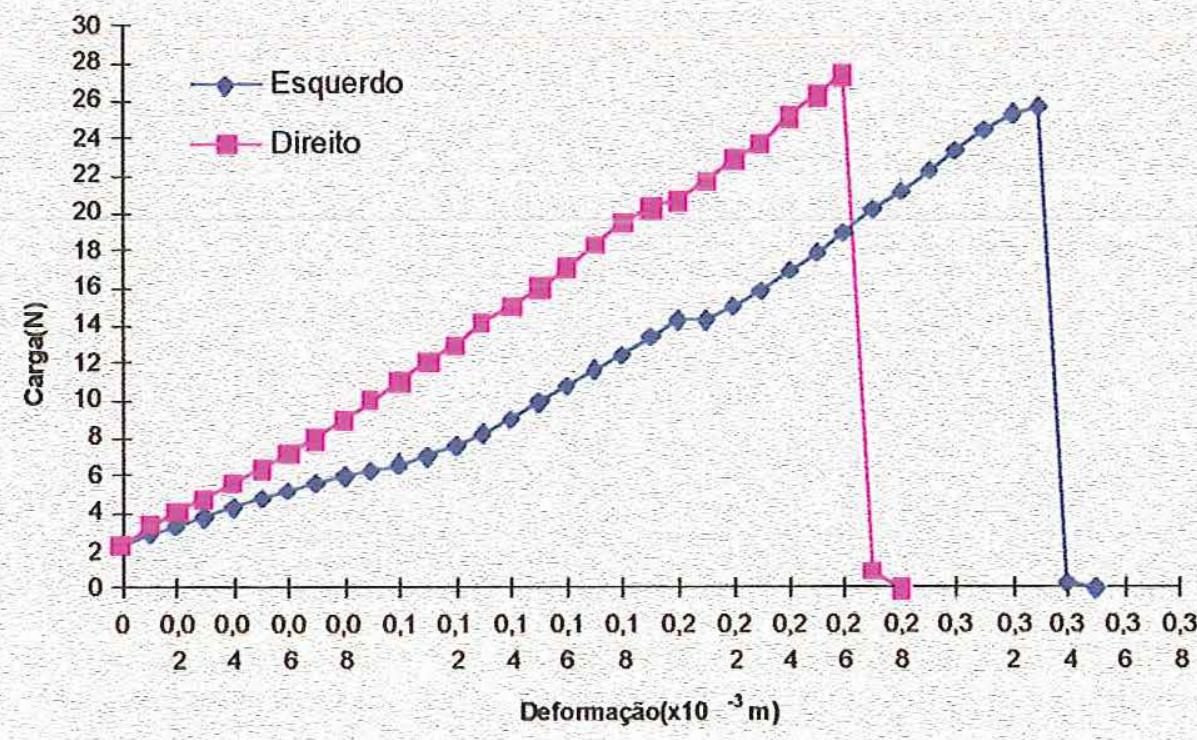



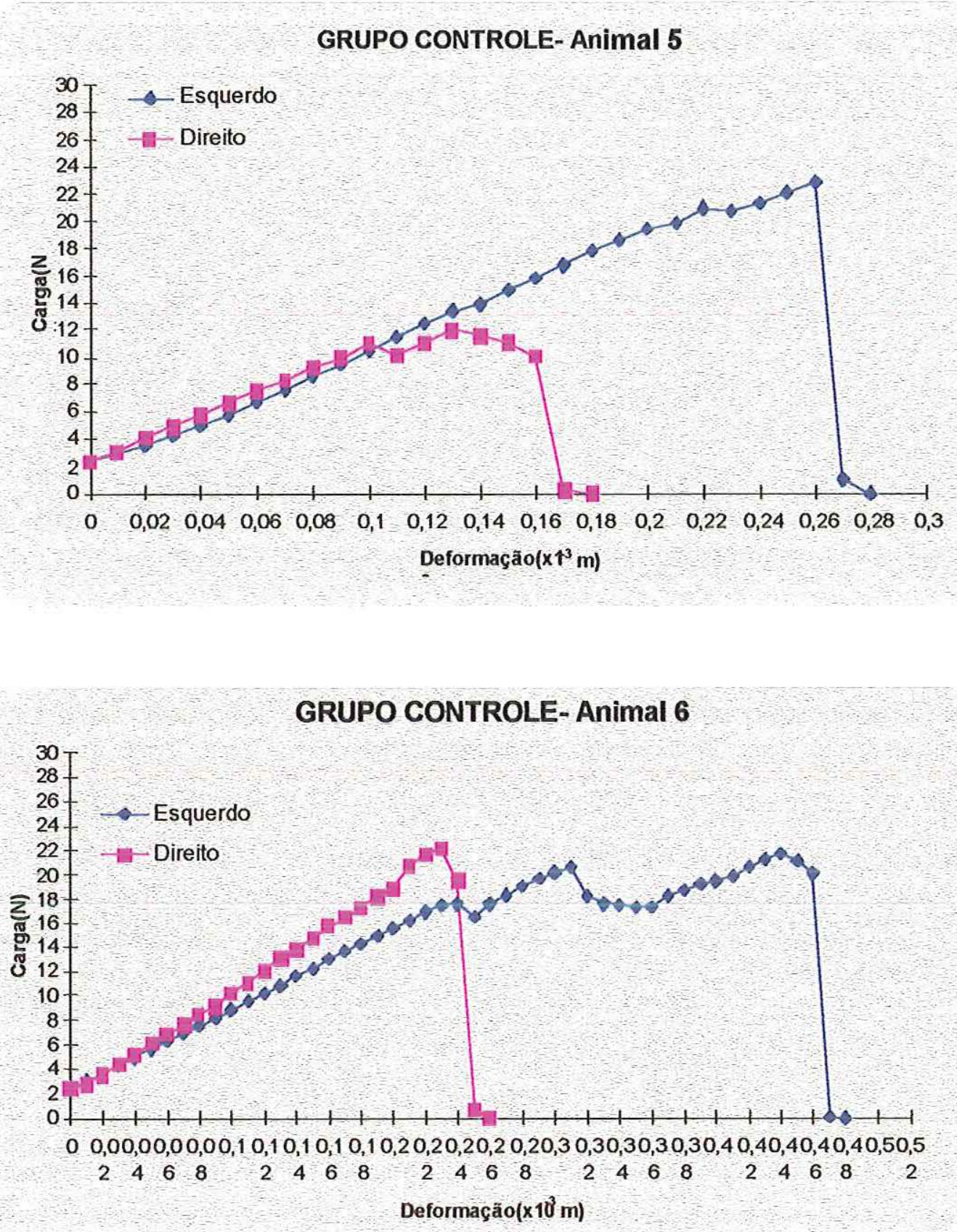


\section{GRUPO CONTROLE- Animal 07}

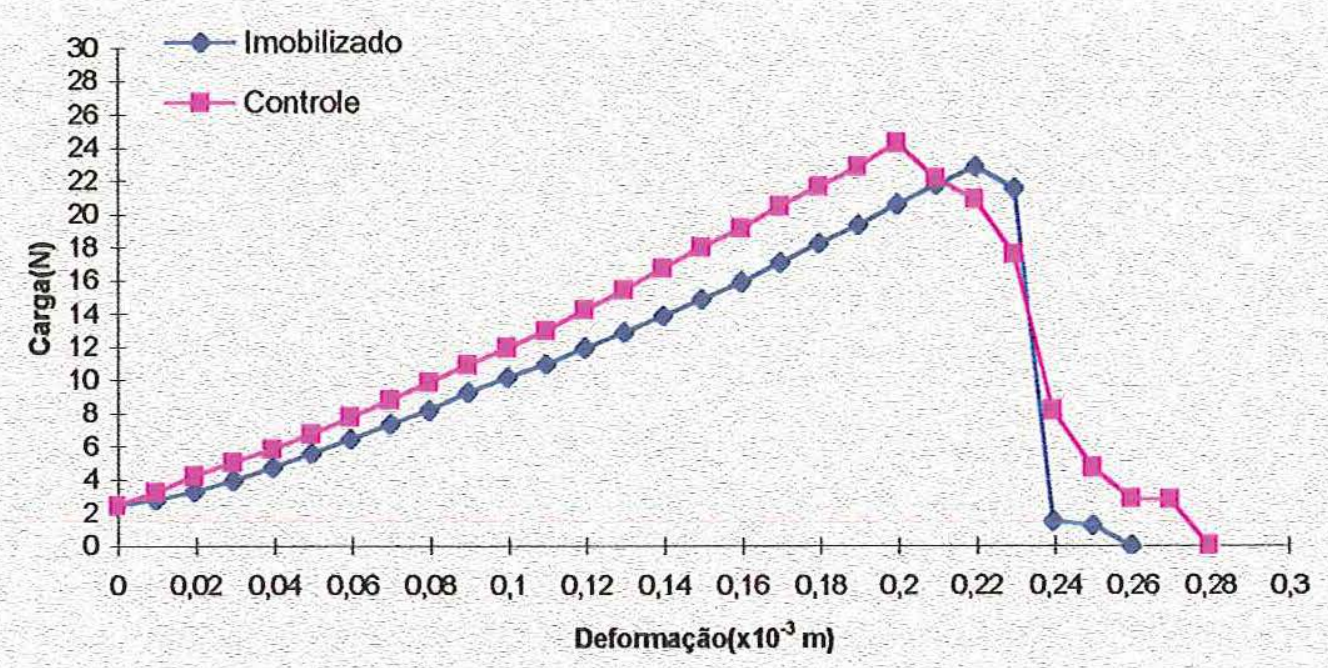

\section{GRUPO CONTROLE-Animal 08}

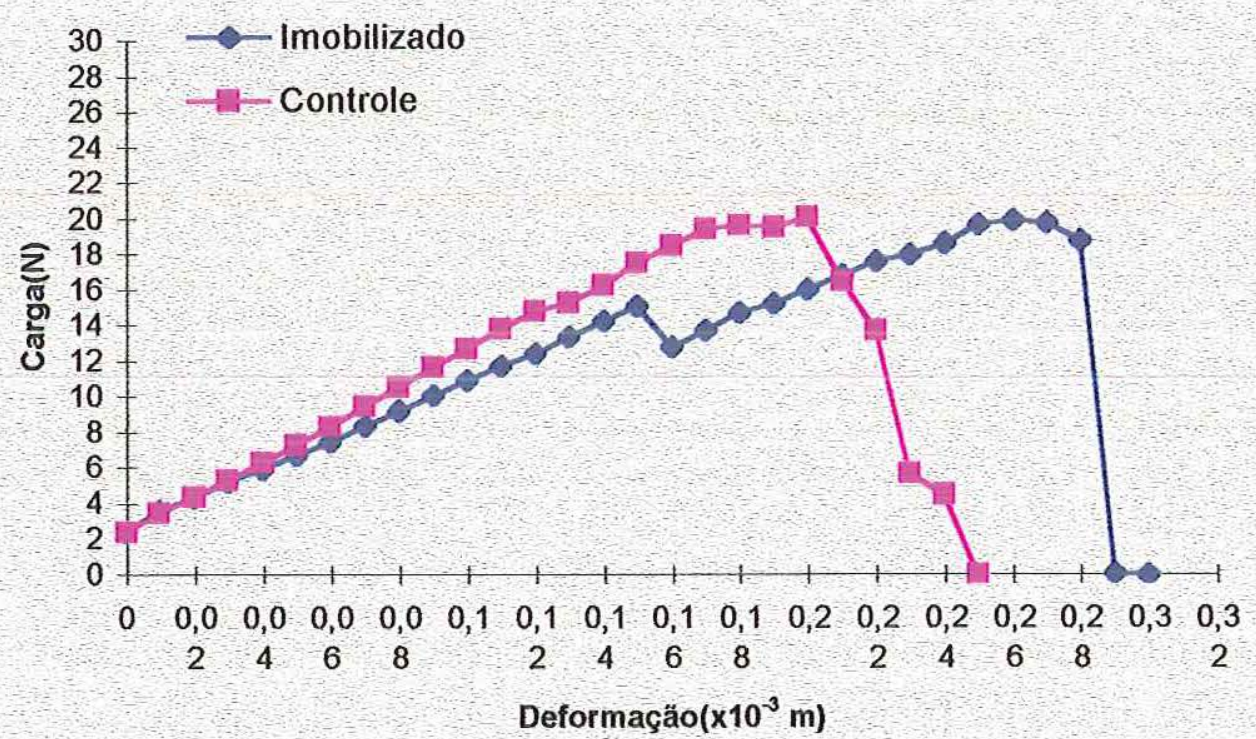




\section{GRUPO CONTROLE- Animal 09}

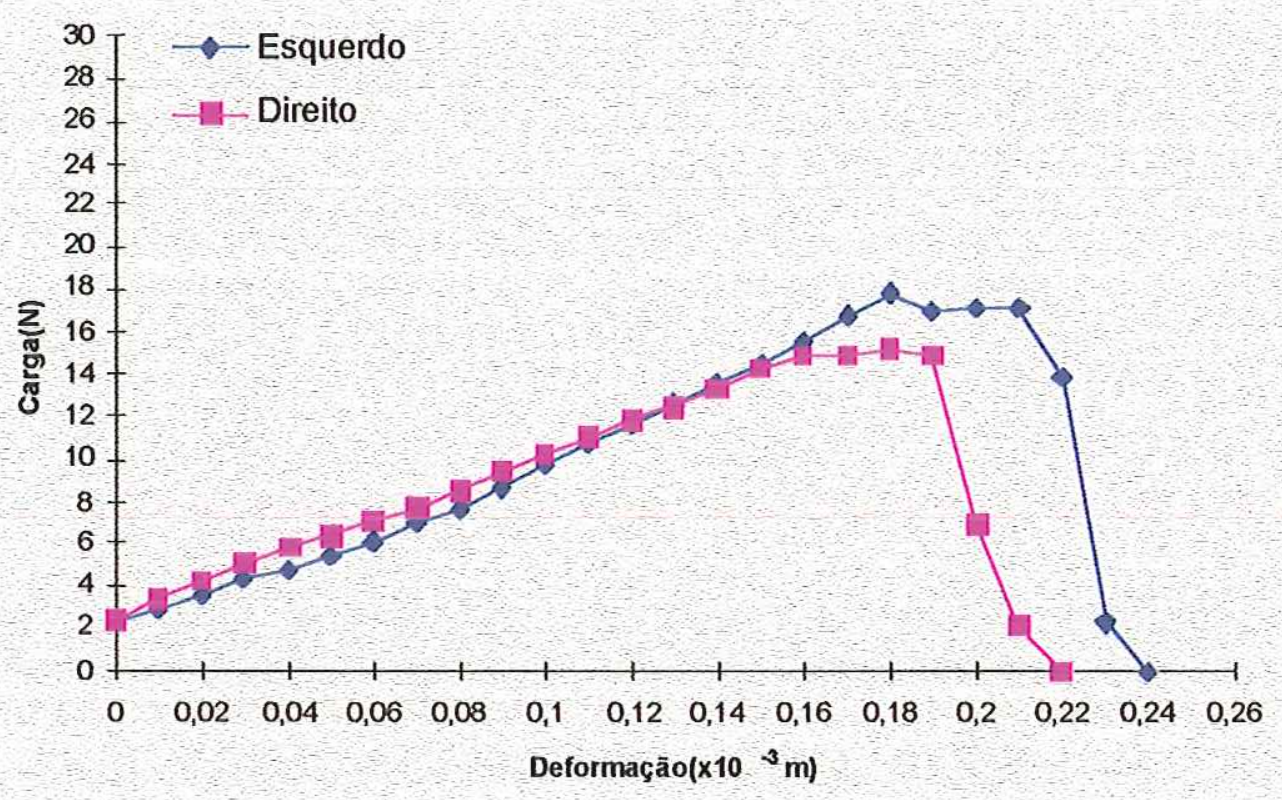

GRUPO CONTROLE-Animal 10

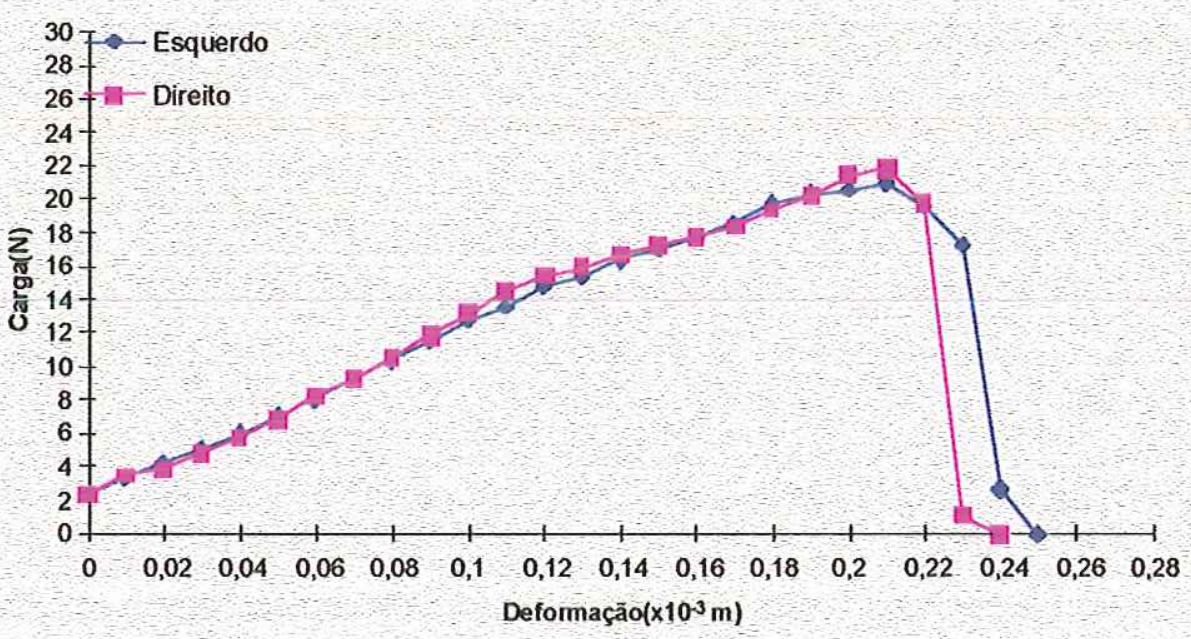




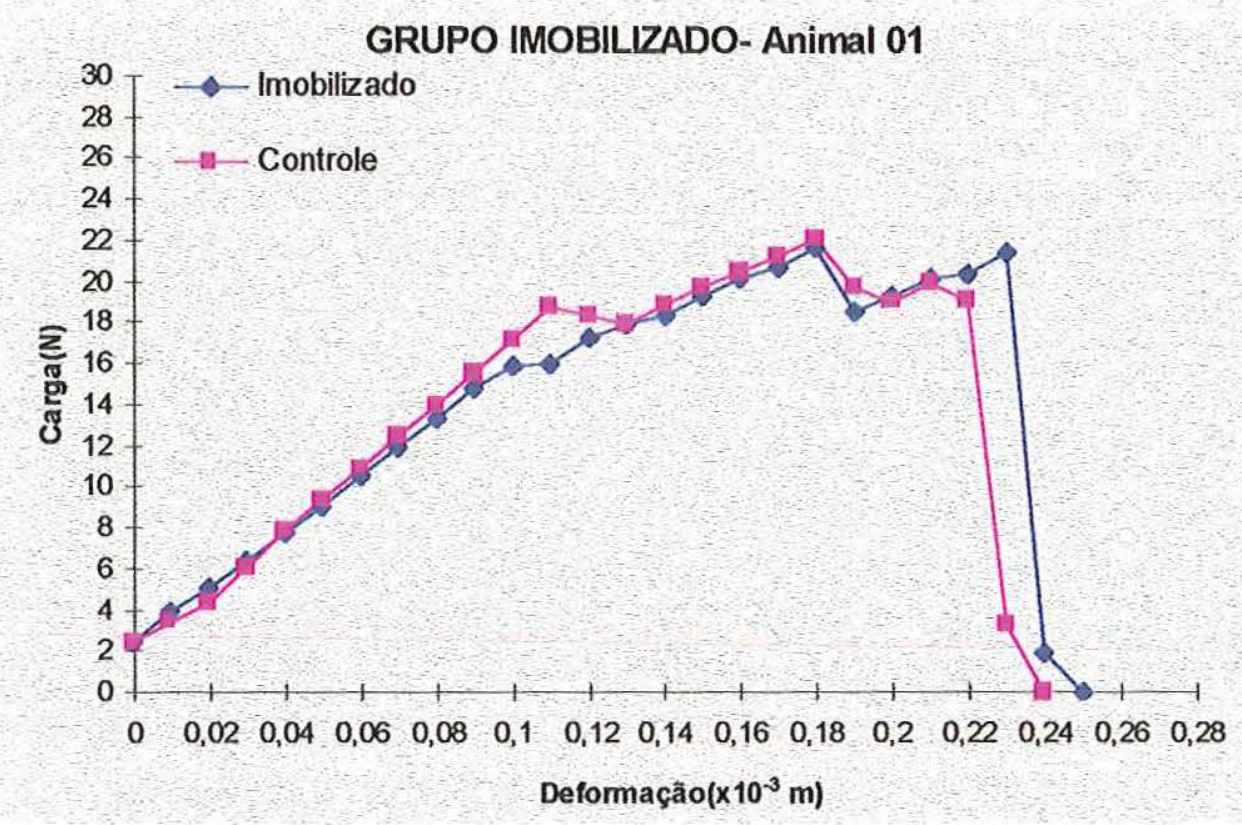

GRUPO IMOBILIZADO- 03

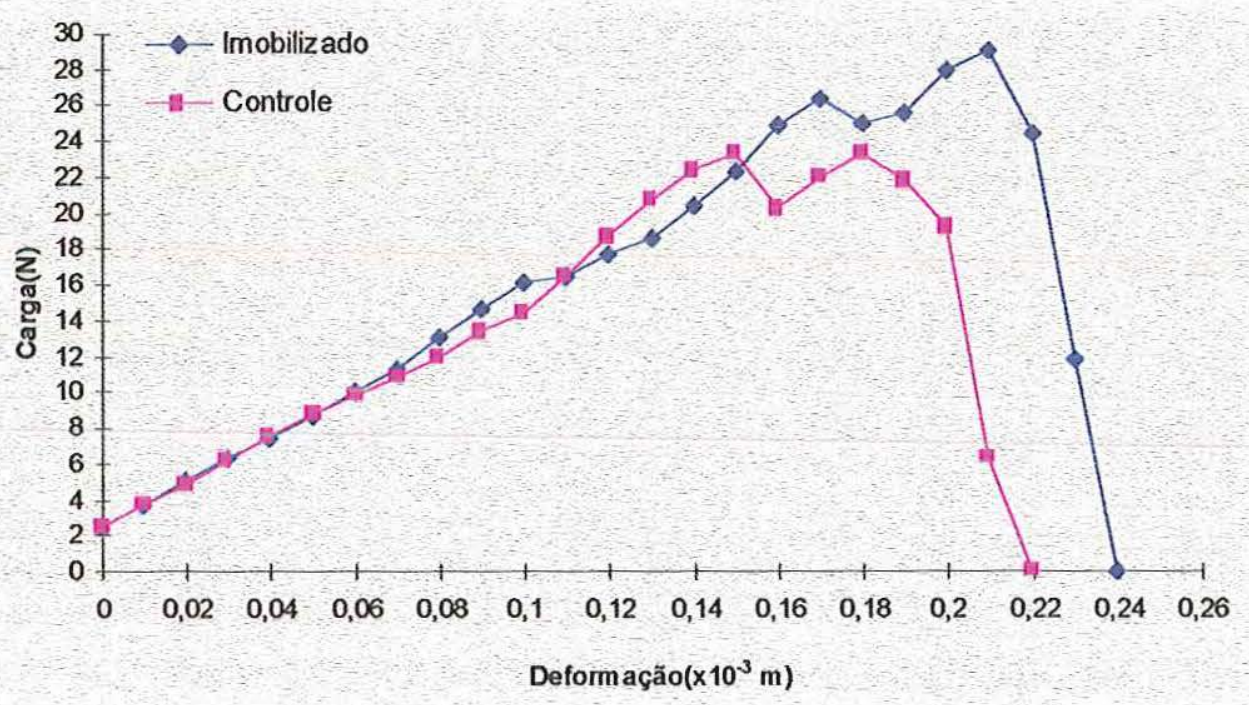


GRUPO IMOBILIZADO- Animal 04

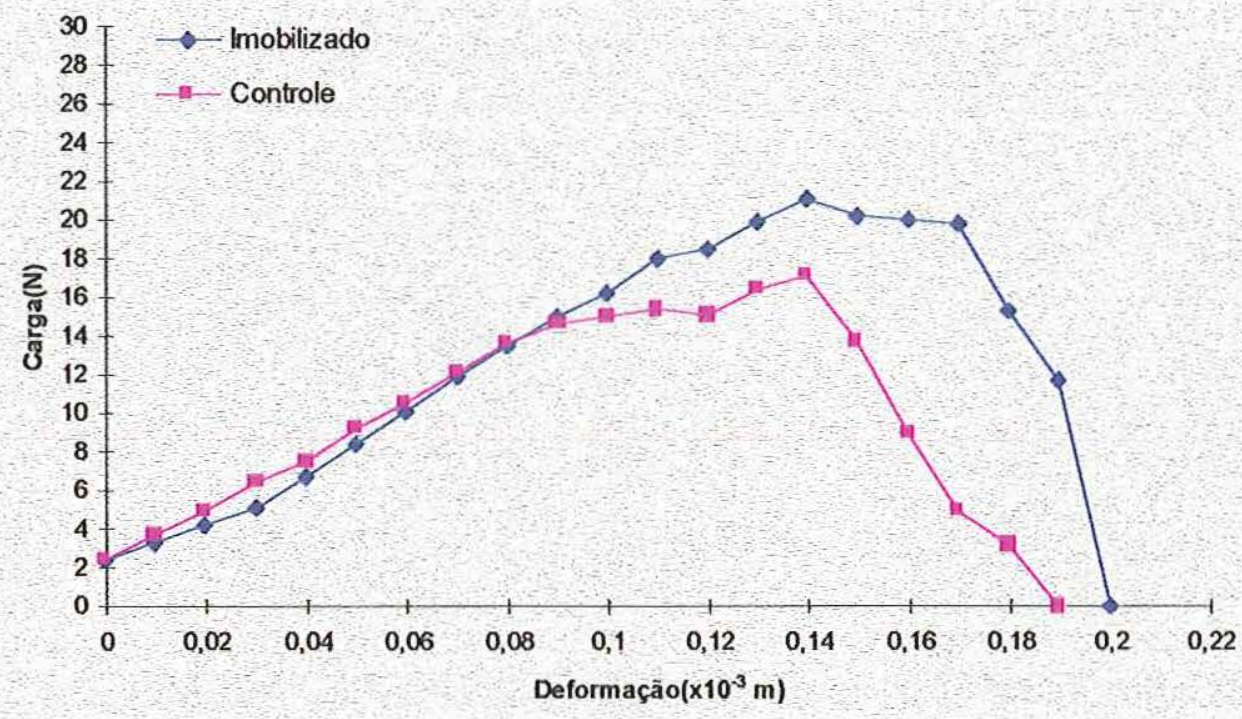

\section{GRUPO IMOBILIZADO- Animal 05}

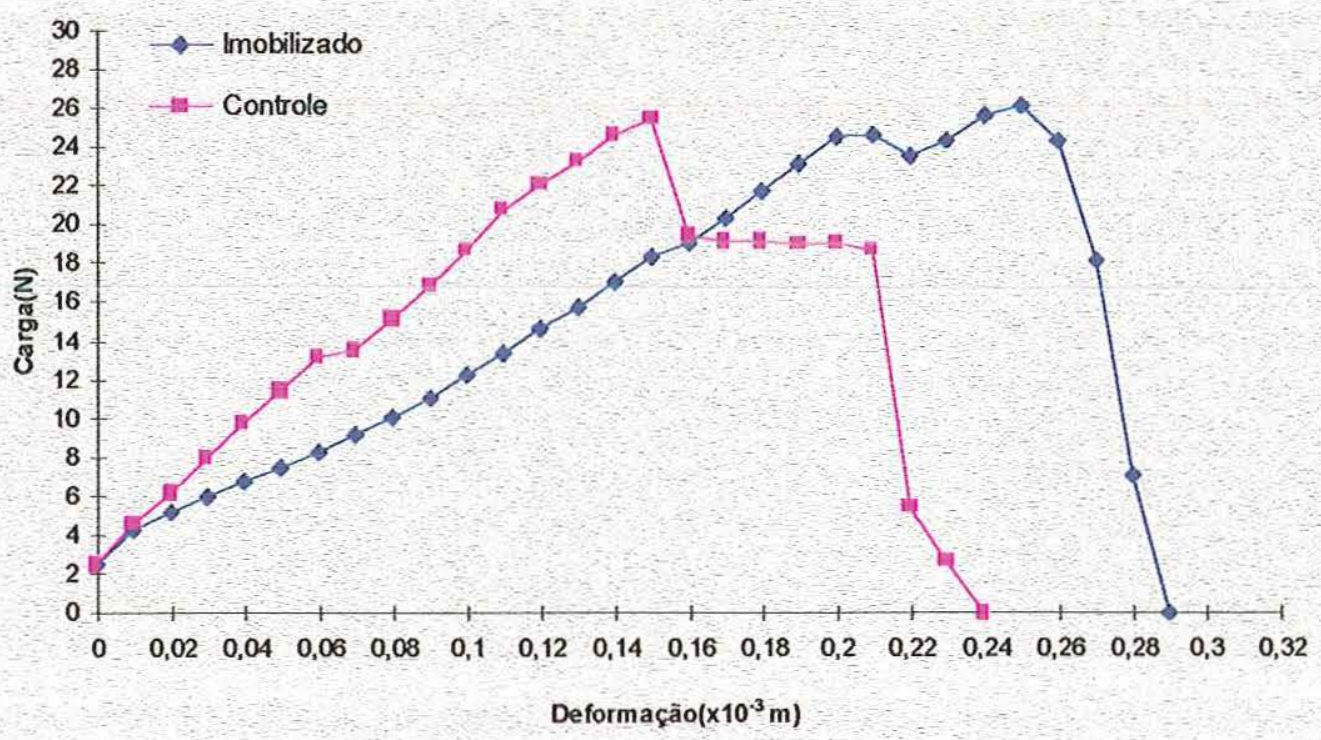




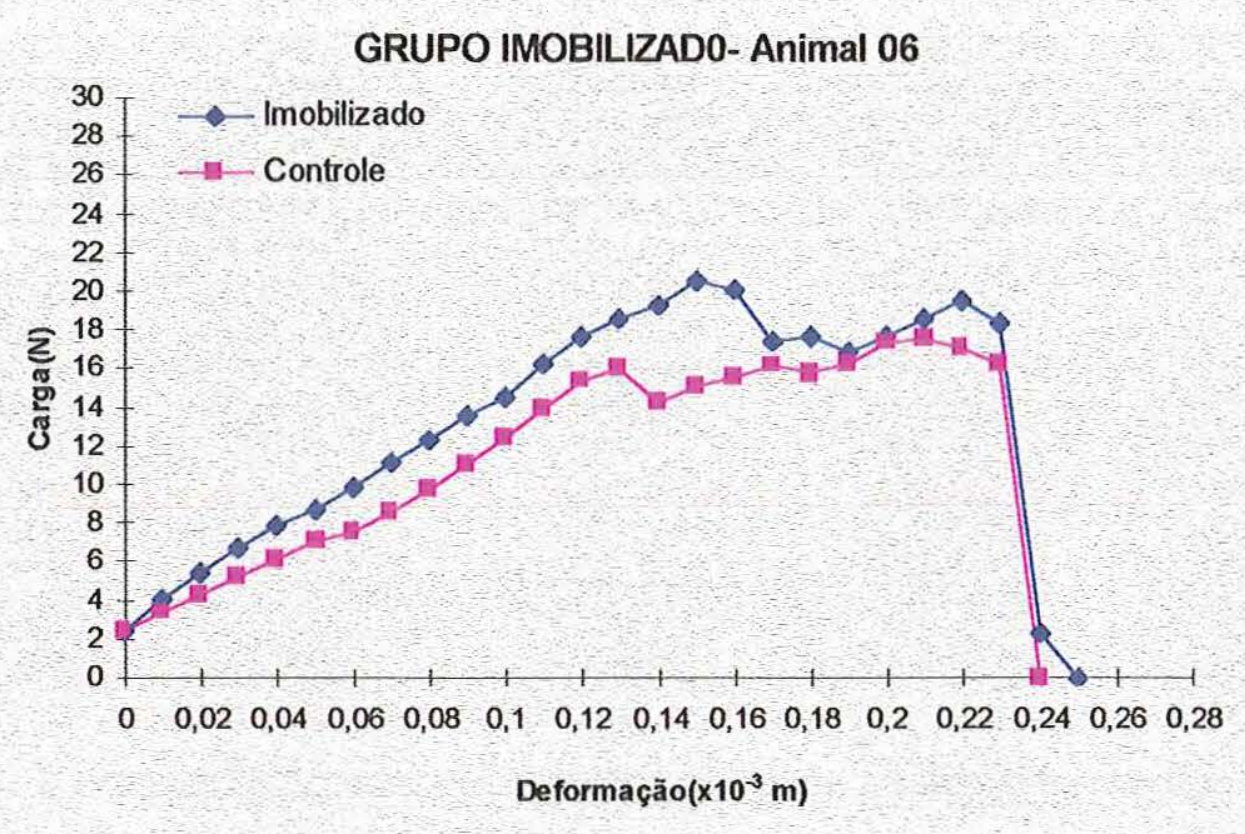

GRUPO IMOBILIZADO-Animal 08

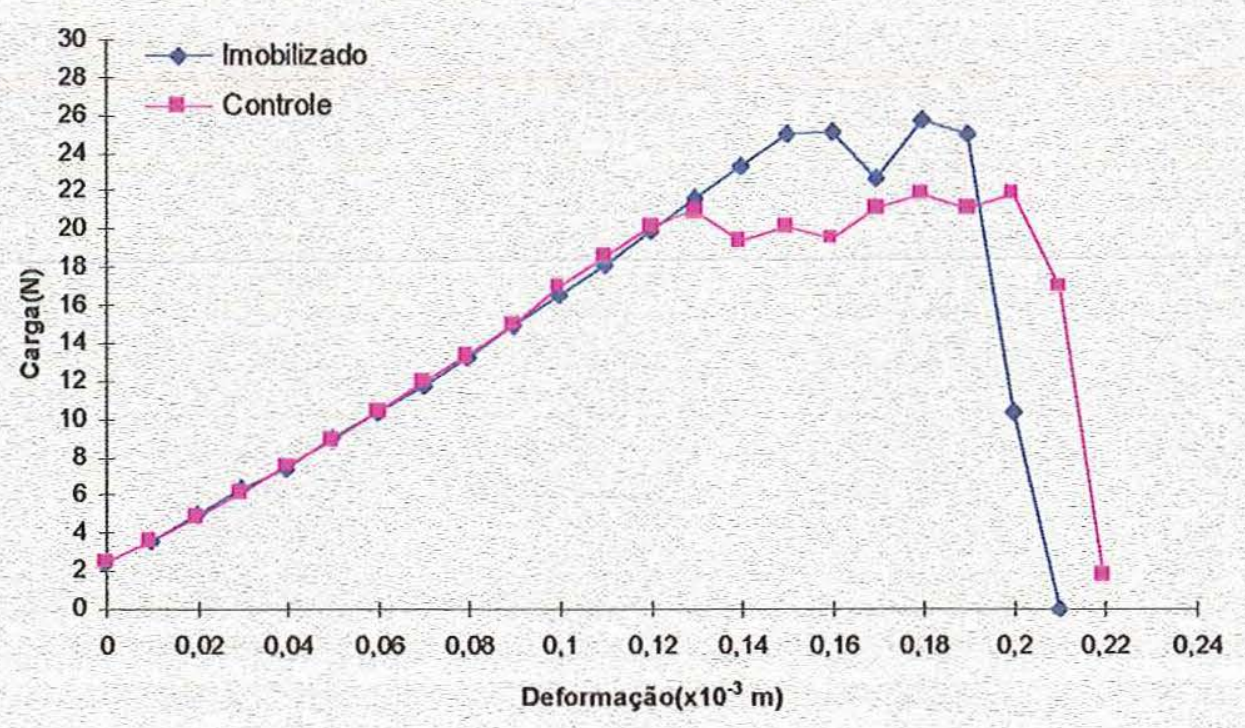




\section{GRUPO IMOBILIZADO- Animal 09}

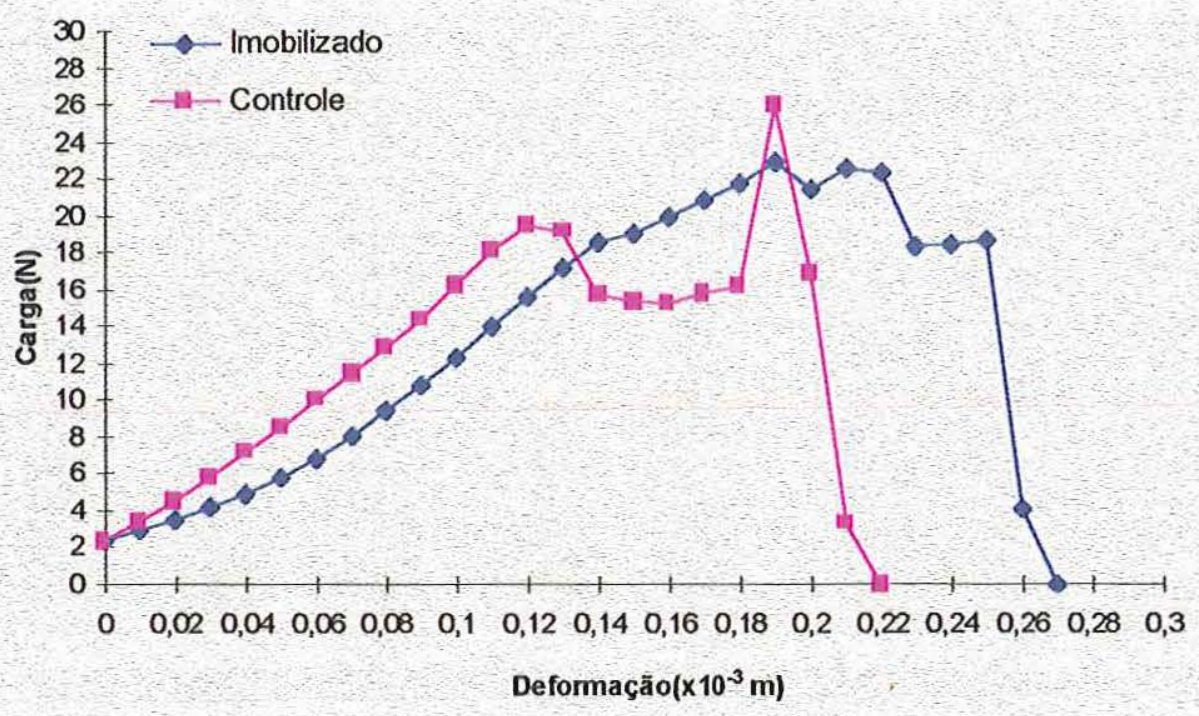

GRUPO IMOBILIZADO- Animal 11

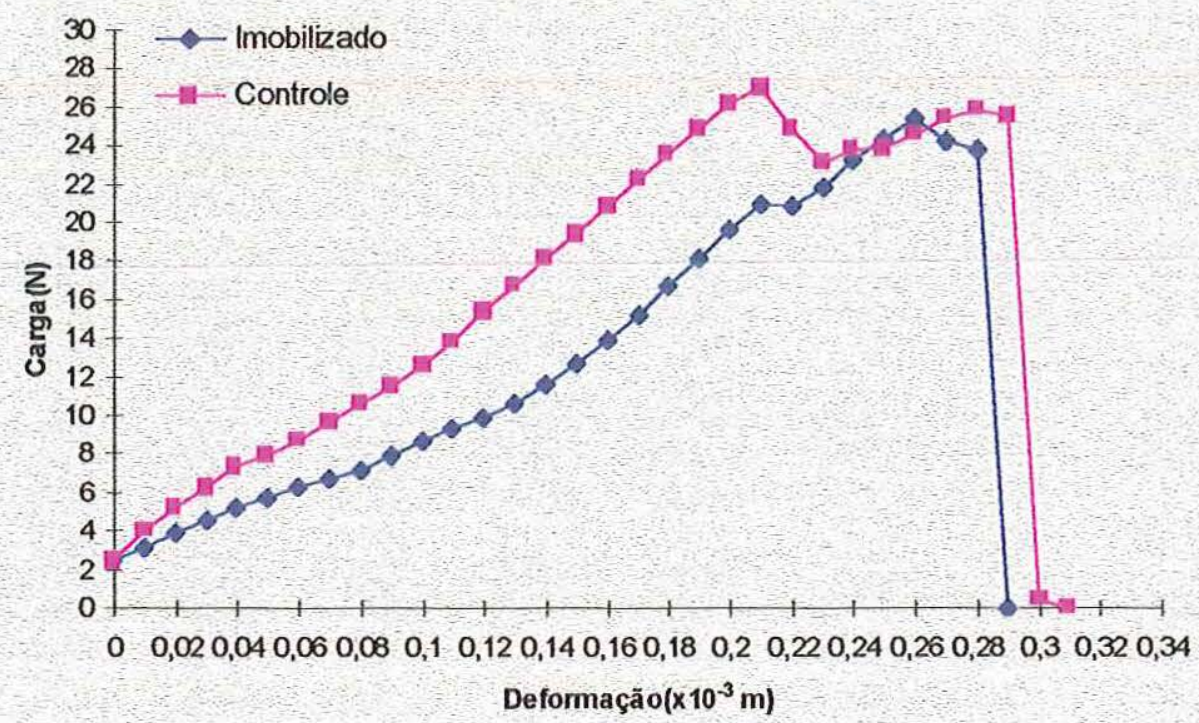




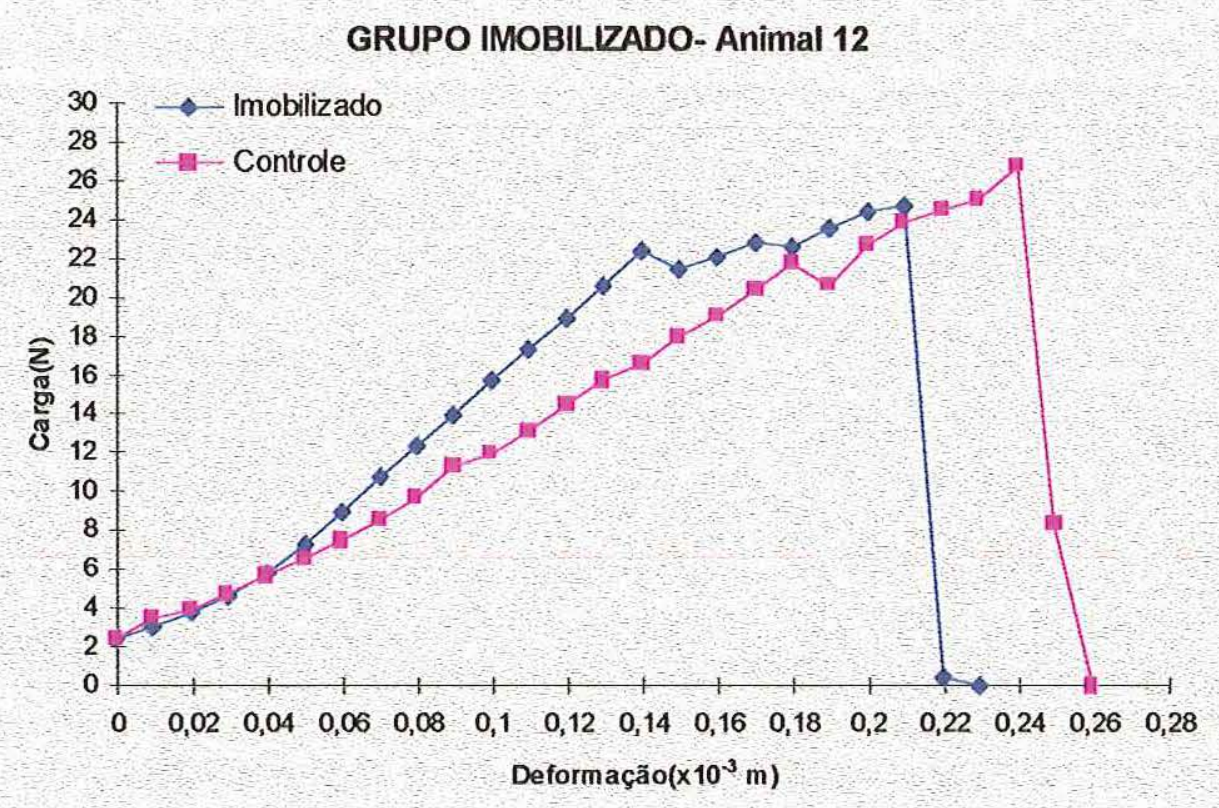

GRUPO IMOBILIZADO- Animal 13

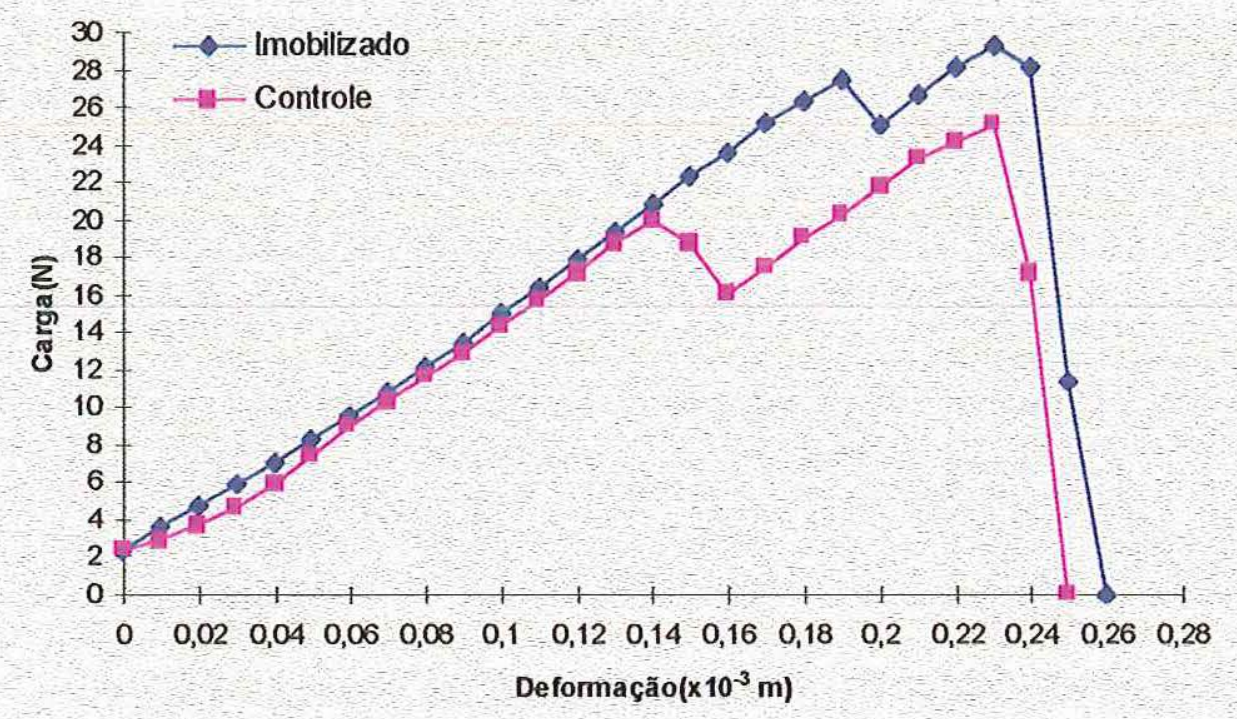




\section{GRUPO IMOBILIZADO- Animal 15}

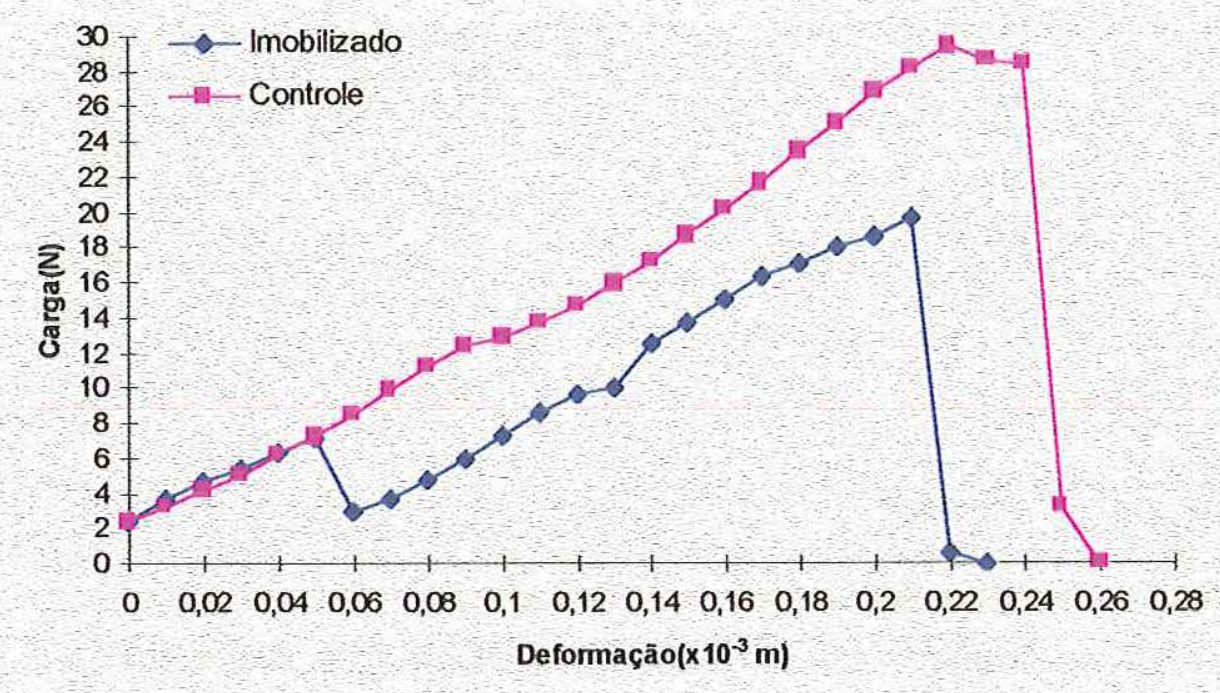

\section{GRUPO IMOBILIZADO-Animal 17}

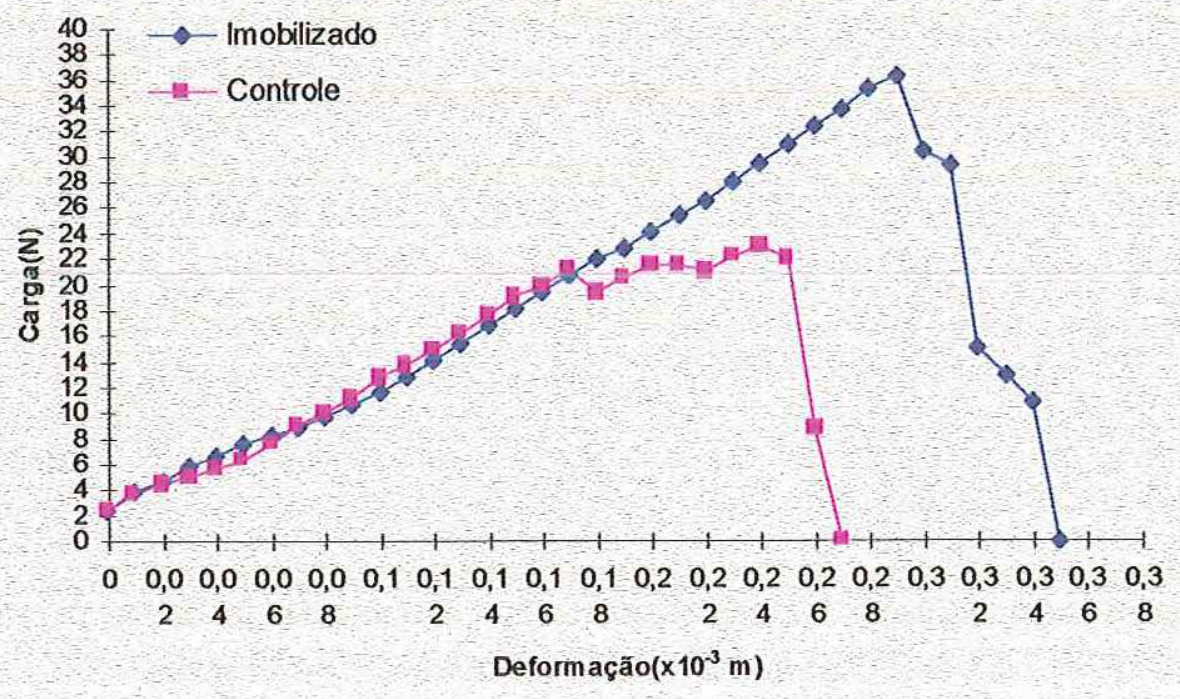




\section{GRUPO IMOBILIZADO- Animal 19}

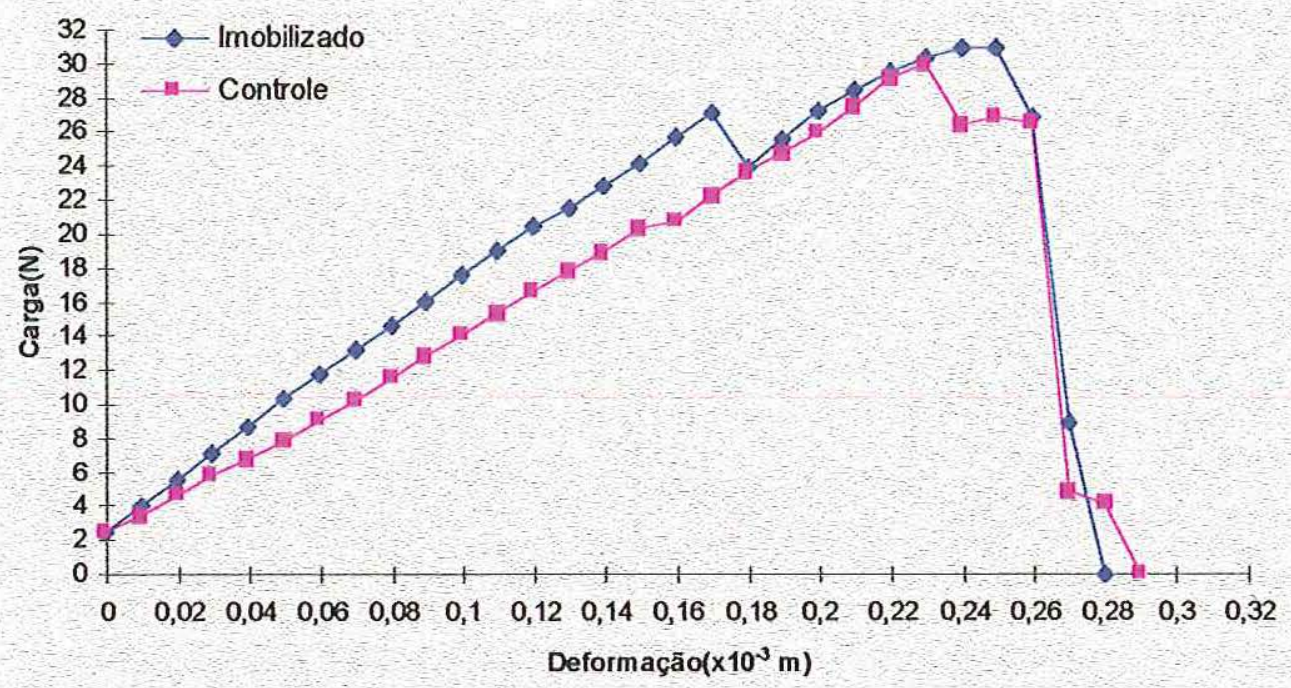

GRUPO IMOBILIZADO-Animal 21

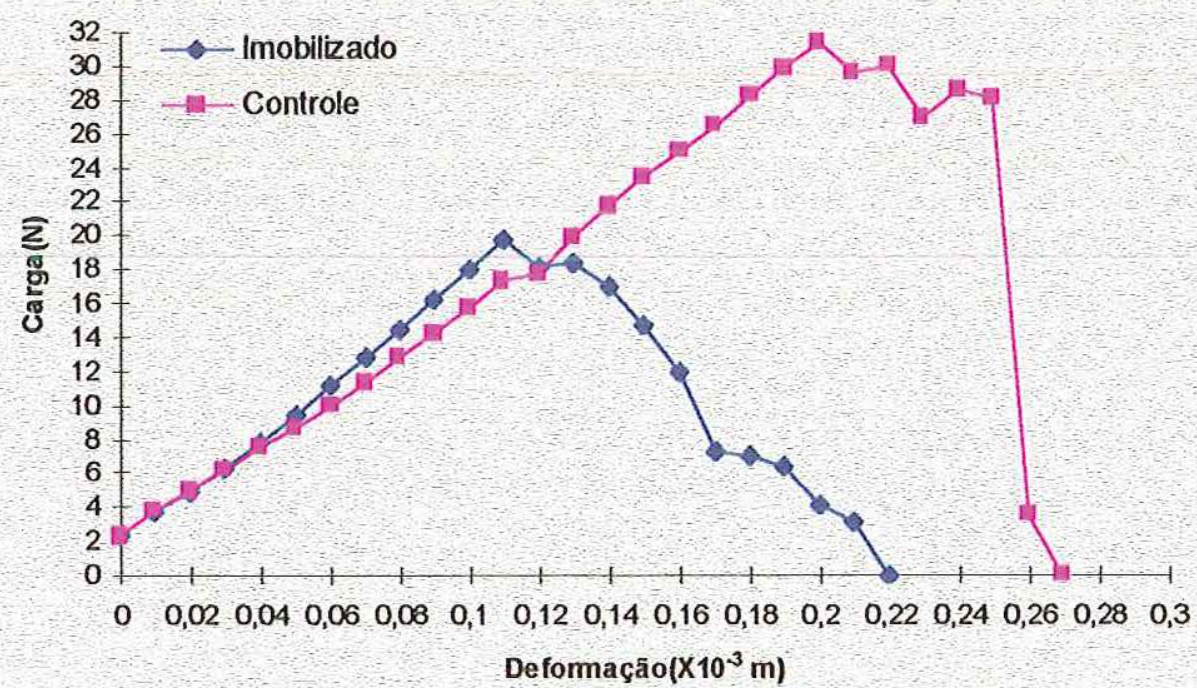




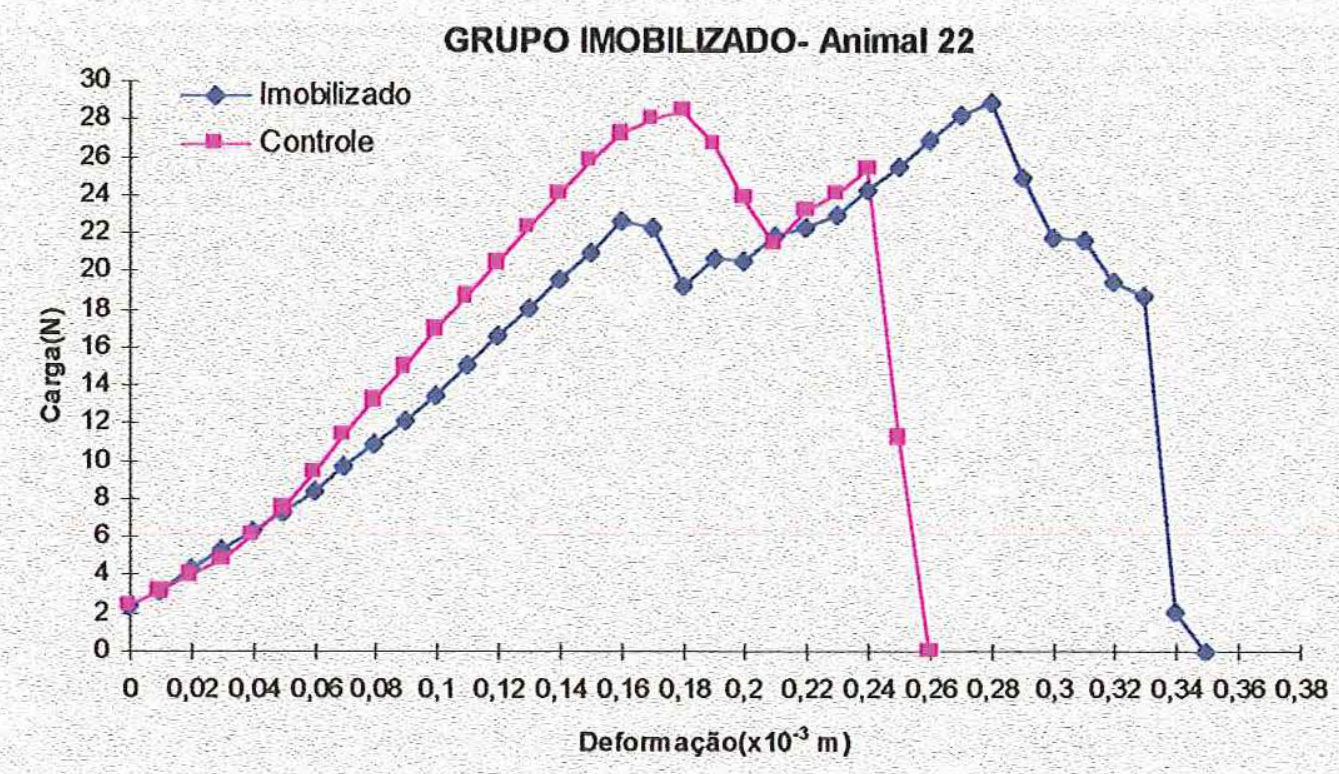

GRUPO IMOBILIZADO- Animal 23

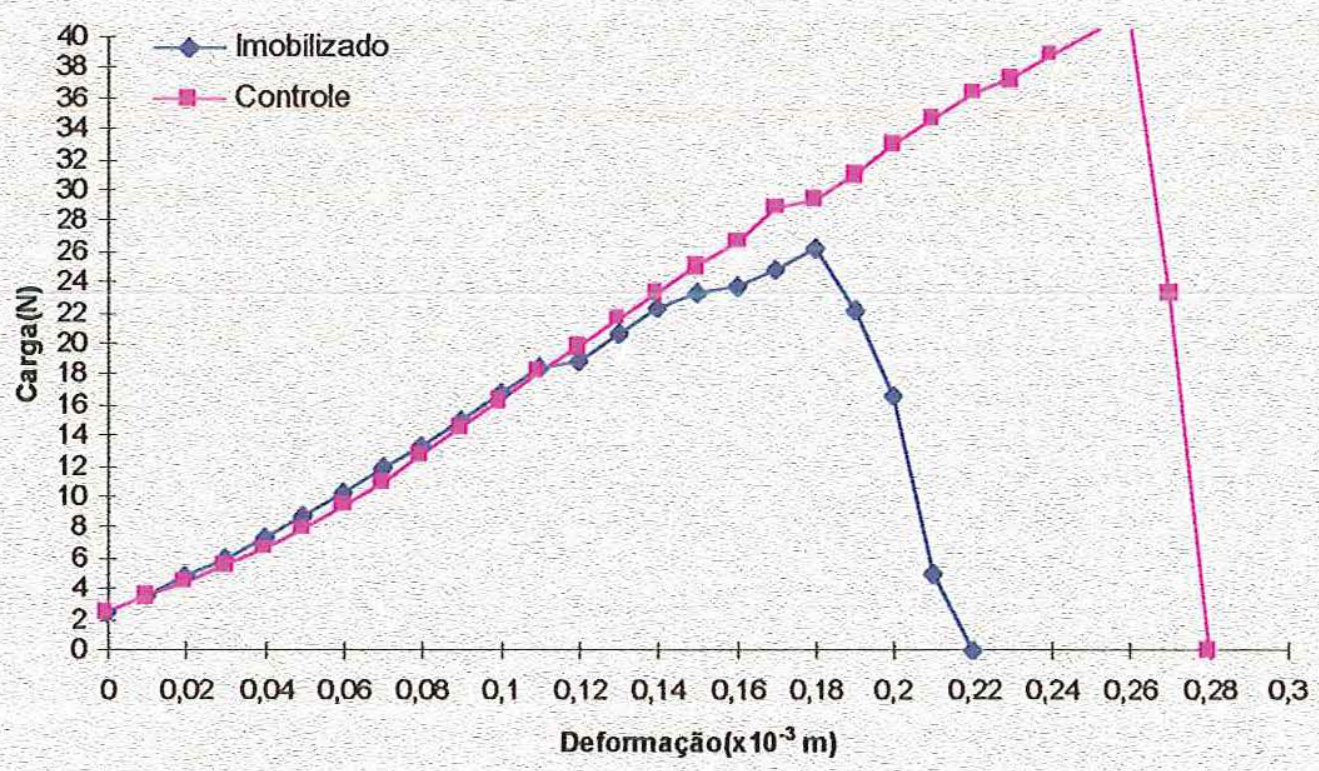



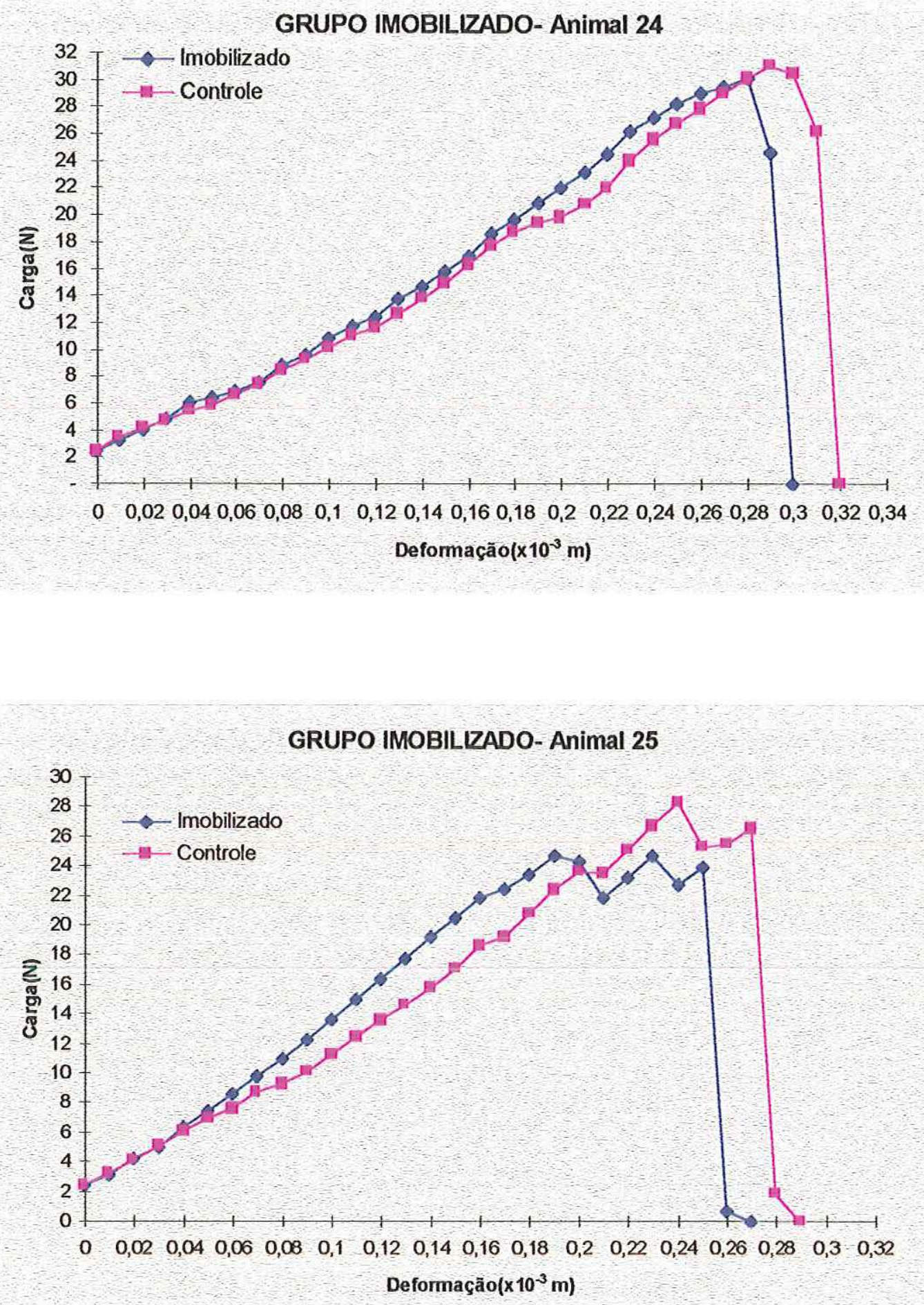

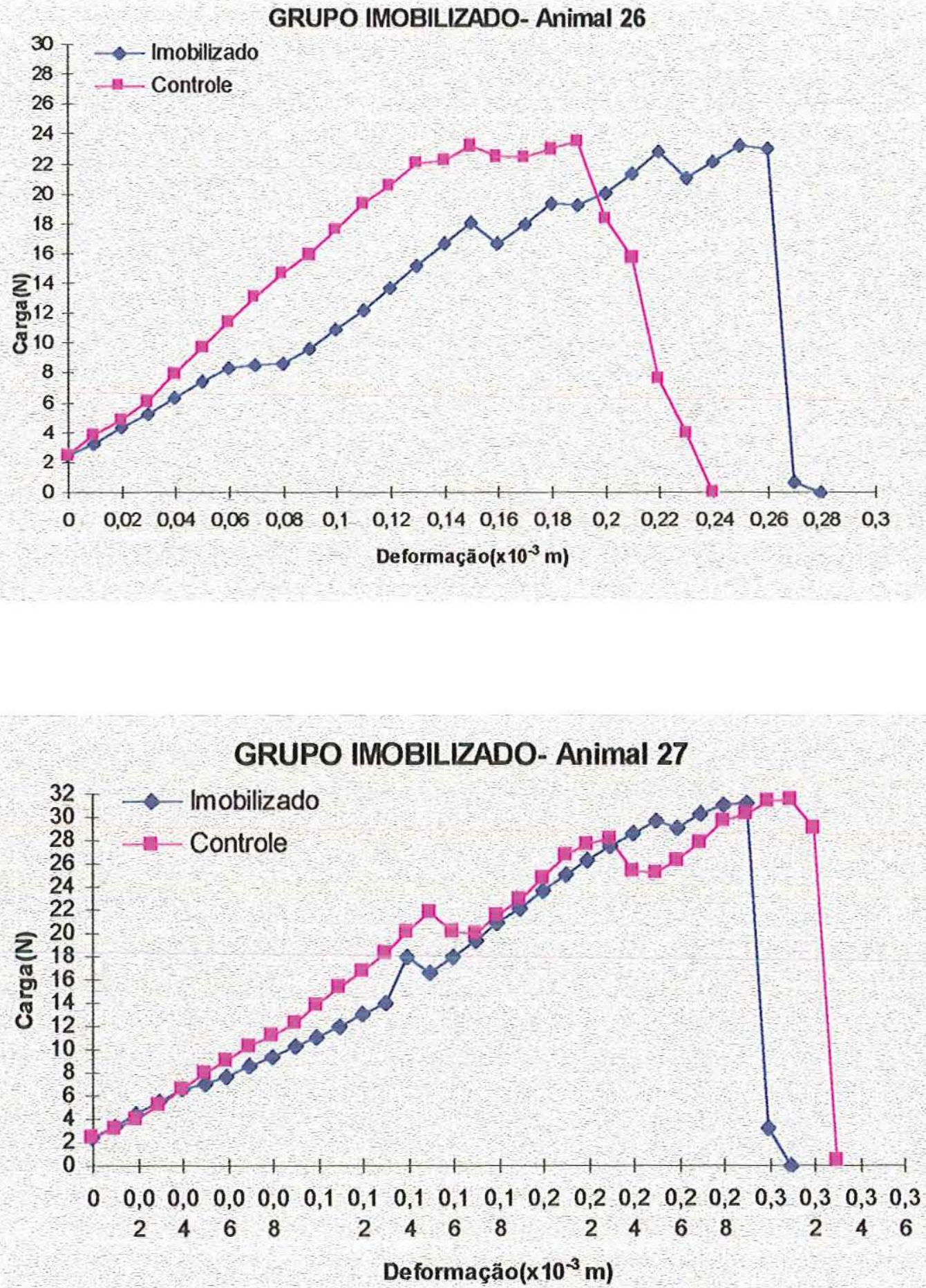

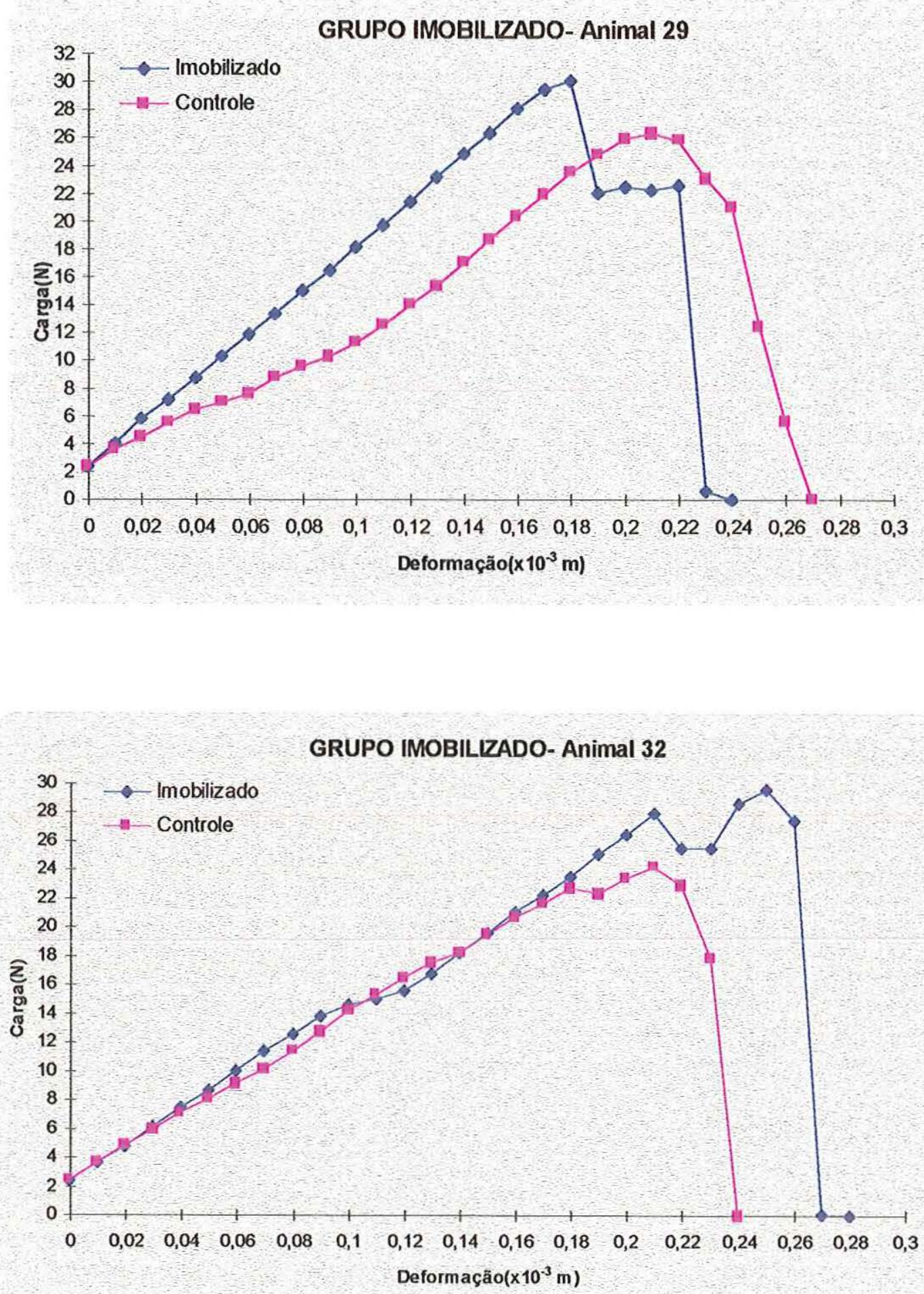

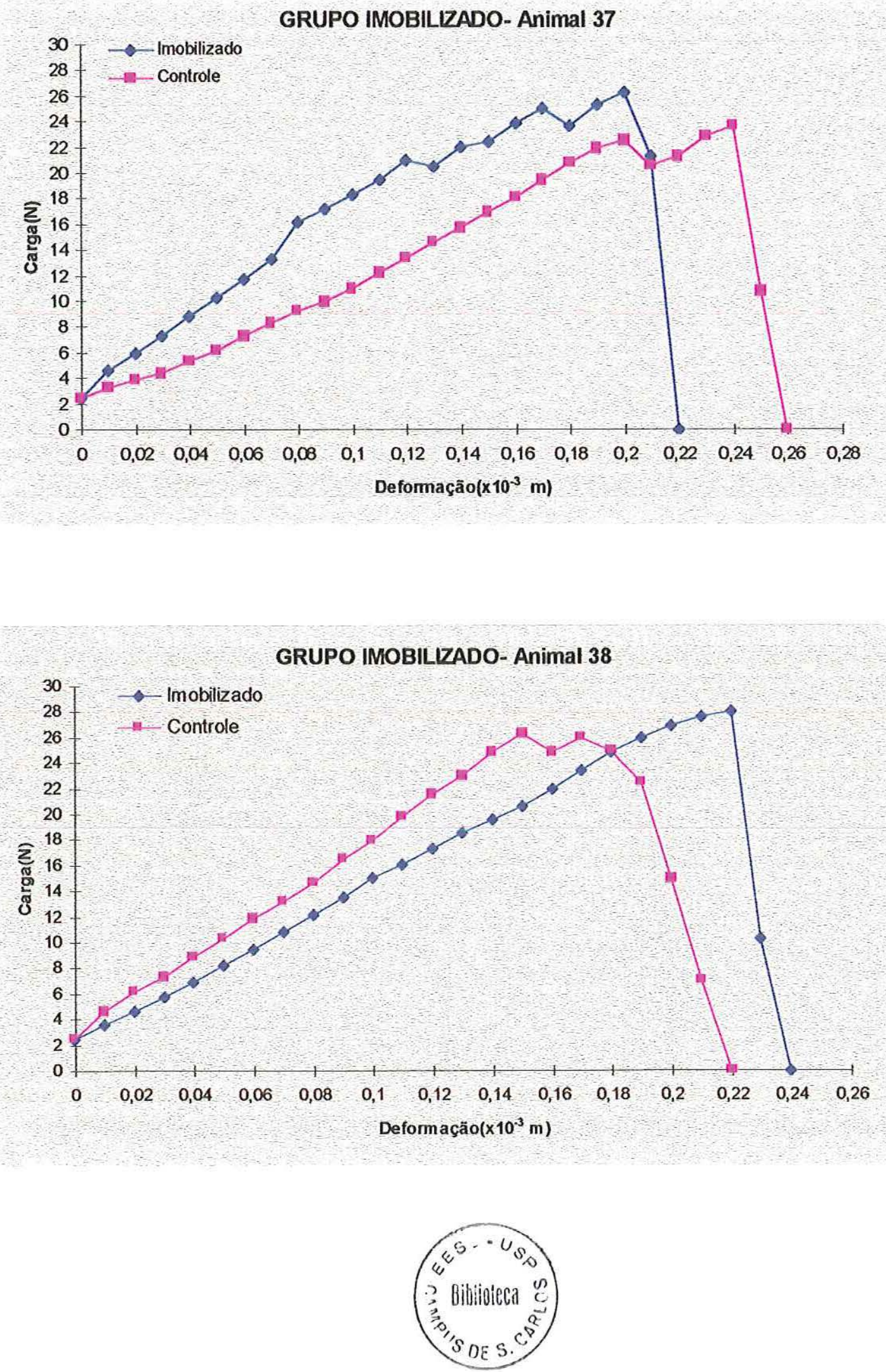


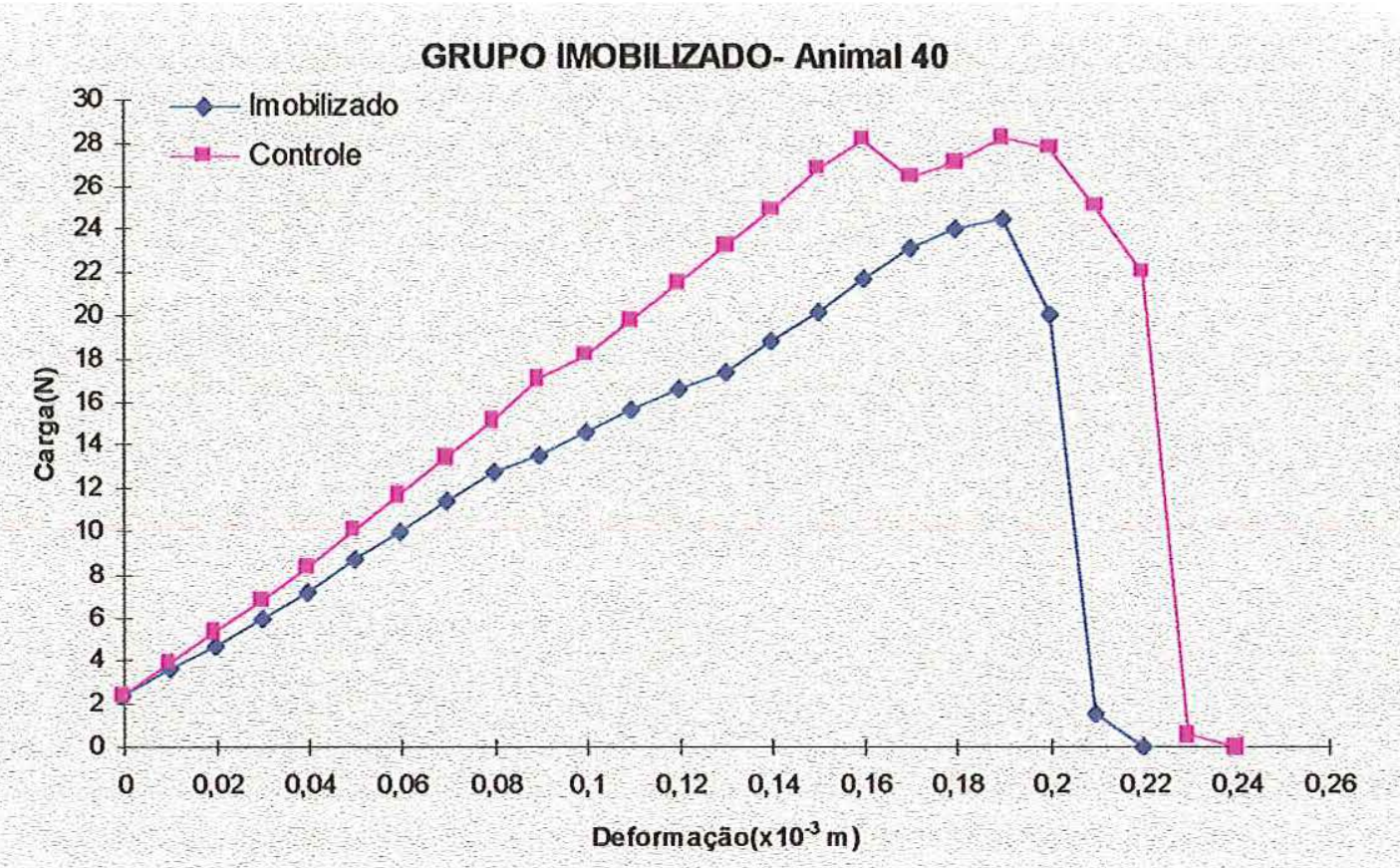




\section{REFERÊNCIAS BIBLIOGRÁFICAS}

AKESON, W. H.; AMIEL, D.; ABEL, M. F.; GARFIN, S. R.; WOO, S. L-Y. Effects of immobilization on joints. Clin. Orthop., 219: 28-37, 1987.

AKESON, W. H.; AMIEL, D.; WOO, S. L-Y. Cartilage and ligament: physiologu and repair processes. In: NICHOLAS,J.A.\& HERSHMAN, E. B. The lower extremity and spine in sports medicine. St. Louis, Toronto, Ed. Mosby. 1986. cap. 1, p. 3-41.

AKESON, W. H.; WOO, S. L-Y.; AMIEL, D.; COUTTS, R. D.; DANIEL, D. The connective tissue response to immobility: biomechanical changes in periarticular connective tissue of the immobilized rabbit knee. Clin. Orthop., 93: 356$362,1973$.

AMIEL, D.; AKESON, W. H.; HARWOOD, F. L.; FRANK, C. B. Stress deprivation effect on metabolic turnover of the medial collateral ligament collagen . Clin. Orthop., 172: 265-270, 1983.

AMIEL, D.; WOO, SL-Y.; HARWOOD, F. L.; AKESON, W. H. - The effect of immobilization on collagen turnover in connective tissue: a biochemical biomechanical correlation. Acta Orthop. Scand.,.53: 325-332, 1982.

BINKLEY, J. M. ; PEAT, M. The effects of immobilization on the ultrastructure and mechanical properties of medial collateral ligaments. Clin. Orthop., 203: 301-308, 1986.

BOOTH, F. W.; TIPTON, C. M. Ligamentous strength measurements in pre-pubescent and pubescent rats. Growth., 34: 177-185, 1970. 
CABAUD, H. E.; CHATTY, A.; GIDENGORIN, V.; FELTMAN, R. J. - Exercise effects on the strenght of the rat anterior cruciate ligament. Am. J. Sports Med., 8: 79-86, 1980.

EVANS, E. B.; EGGERS, G. W. N.; BUTLER, J. K.; BLUMEL, J. Experimental immobilization and remobilization of rat knee joint. J. Bone Joint Surg., 42-A: 737$758,1960$.

HORWITZ, M. T. Injuries of the ligaments of the knee joint. Arch. Surg. 38: 946-954, 1939.

JOHNSON, R. J. - The anterior cruciate ligament problem. Clin. Orthop., 172: 14-18, 1983.

JUNQUEIRA, L. C. U.; MARTINS, E. O. Atlas de anatomia microscópica do rato. Publicação da Universidade de São Paulo, São Paulo, 1947, p. 92-97.

KAPANJI, I. A. Fisiologia Articular. $5^{\circ}$ edição. São Paulo, Editora Manole, 1987. cap.2, p. 74-157. Joelho.

MARCONDES DE SOUZA, JP.; MACHADO, FF.; SESSO, A.; VALERI, V.: Imobilização articular experimental em cobaias. Efeitos sobre a juntura do joelho. Rev. Ass. Med. Brasil., 10,7:159-175,1964.

MARTIN, A. F. The pathomecanics of the knee joint. I. The medial collateral ligament and lateral tibial plateau fractures. J. Bone Joint Surg., 42 A: 13-22, 1960.

MILTNER, L. J.; C. H. HU; H. C. FANG. Experimental joint sprain: pathologic study. Arch. Surg., 35: 234-240, 1937.

NOYES, F. R. -Functional properties of knee ligaments and alterations induced by immobilization: a correlative biomechanical and histological study in primates. Clin. Orthop., 123: 210-242, 1977. 
NOYES, F. R.; TORVIK, P. J.; HYDE, W. B.; DeLUCAS, J. L. Biomechanics of ligament failure. J. Bone Joint Surg., 56-A: 1406-1418, 1974.

PADGETT, L. R. \& DAHNERS, L. E. Rigid immobilization alters matrix organization in the injured rat medial collateral ligament. J. Orthop. Res., 10: 895-900, 1992.

RASCH, P. J.; MANISCALCO, R.; PIERSON, W. R.; LOGAN, A. G. Effect of exercise, immobilization and intermittent stretching on strength of knee ligaments of albino rats. J. Appl. Phys., 15: 289-290, 1960.

SMITH, J. W. The elastic properties of the anterior cruciate ligament of the rabbit. J. Anat., 88: 396-380, 1954

TIPTON, C. M.; JAMES, S. L.; MERGNER, W.; TCHENG, T. Influence of exercise on strength of medial collateral knee ligaments of dogs. Am. J. Physiol., 218: 894-902, 1970.

TIPTON, C. M.; SCHILD, R. J.; TOMANEK, R. J. Influence of physical activity on the strength of knee ligaments in rats. Am. J. Physiol., 212: 783-787, 1967a.

TIPTON, C. M.; SCHILD, R. J.; FLATT, A. E. Measurement of ligamentous strength in rat knees. J. Bone Joint Surg., 49-A: 63-72, 1967b.

TIPTON, C. M.; MATTHES, R. D.; MAYNARD, J. A.; COREY, R. A. The influence of physical activity on ligaments and tendons. Med. Sci. Sports, .7: 165-175, 1975.

TIPTON, C. M.; MATTHEUS, R. D.; MARTIN, R. K. Influence of age and sex on the strenght of bone-ligament junctions in knee joints of rats. J. Bone Joint Surg., 60-A: 230-234, 1978. 
WOO, S. L-Y; GOMEZ, M. A.; SITES, T. J.; NEWTON, P. O.; ORLANDO, C. A.; AKESON, W. H. The biomechanical and morphological changes in the medial collateral ligament of the rabbit after immobilization and remobilization. J. Bone Joint Surg., 69-A: 1200-1211, 1987.

WOO, S. L-Y; SMITH, B. A.; JOHNSON, G. A. Biomechanics of knee ligaments. In: FU, F. H.; HARNER, CD \& VINCE. Knee Surgery. $1^{\text {a }}$ edição. Williams \& Wilkins, Baltimore, 1994. Cap.7, p. 155-187.

ZUCKERMAN, J. \& STULL, G. A. Effects of exercise on knee ligament separation force in rats. J. Appl. Physiol., 26: 716-719, 1969. 


\section{APÊNDICE 1}

TABELA I - Peso dos animais do grupo controle quando foram sacrificados.

\begin{tabular}{cc}
\hline Animal Poso(gras) \\
\hline 1 & 325 \\
2 & 320 \\
3 & 345 \\
4 & 340 \\
5 & 335 \\
6 & 335 \\
7 & 330 \\
8 & 340 \\
9 & 330 \\
10 & 330 \\
\hline
\end{tabular}

Média: $340 \mathrm{~g}$

Desvio Padrão: 7,949

Variância: 63,194 
TABELA II - Peso inicial e final dos animais do grupo imobilizado.

\begin{tabular}{|c|c|c|}
\hline Aninal & $\begin{array}{l}\text { Pesolinitial } \\
\text { (gramins) }\end{array}$ & 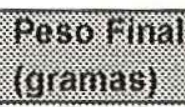 \\
\hline 1 & 325 & 365 \\
\hline 3 & 335 & 385 \\
\hline 4 & 340 & 355 \\
\hline 5 & 350 & 385 \\
\hline 6 & 310 & 295 \\
\hline 8 & 390 & 370 \\
\hline 9 & 340 & 390 \\
\hline 11 & 320 & 350 \\
\hline 12 & 320 & 345 \\
\hline 13 & 320 & 315 \\
\hline 15 & 330 & 325 \\
\hline 17 & 330 & 350 \\
\hline 19 & 365 & 350 \\
\hline 21 & 300 & 375 \\
\hline 22 & 345 & 335 \\
\hline 23 & 360 & 325 \\
\hline 24 & 310 & 335 \\
\hline 25 & 315 & 315 \\
\hline 26 & 360 & 390 \\
\hline 27 & 380 & 435 \\
\hline 29 & 340 & 355 \\
\hline 32 & 320 & 315 \\
\hline 37 & 345 & 370 \\
\hline 38 & 340 & 355 \\
\hline 40 & 385 & 385 \\
\hline
\end{tabular}

Foram então, obtidos os seguintes valores:

Tabela III - Valores de média e desvio padrão para o peso inicial e final dos animais

\begin{tabular}{|c|c|c|c|c|}
\hline & 筮 & Mesia & S Bosvio Thadro & Wrandata \\
\hline Peso mictal! & 25 & 340 & 23,935 & 572,91 \\
\hline 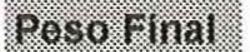 & 25 & 340 & 23,935 & 572,91 \\
\hline
\end{tabular}




\section{APÊNDICE 2}

Valores da Área, calculados através dos dados apresentados nos gráficos (Anexo A), os quais foram transformados em Jaule, para se obter a energia absorvida pelo ligamento até a sua ruptura.

TABELA I - Valores da Área, apresentados pelo grupo controle.

\begin{tabular}{|c|c|c|}
\hline \multicolumn{3}{|c|}{ Área (g.mm) } \\
\hline Animal & Esquerdo & Direito \\
\hline 1 & 295,53 & 266,54 \\
\hline 2 & 325,02 & 351,1 \\
\hline 3 & 317,05 & 140,91 \\
\hline 4 & 425,04 & 392,88 \\
\hline 5 & 356,41 & 113,52 \\
\hline 6 & 405 & 298,23 \\
\hline 7 & 279,94 & 319,79 \\
\hline 8 & 340,23 & 269,65 \\
\hline 9 & 187,3 & 188,82 \\
\hline 10 & 290,58 & 294,79 \\
\hline
\end{tabular}

Foram então, obtidos os seguintes valores para Média e Desvio Padrão.

(TABELA II)

TABELA II - Valores para Média e Desvio Padrão, em relação à Área, para o grupo controle.

\begin{tabular}{|l|lll}
\hline & $n$ & Media & Desvio Prodräo \\
\hline \hline Esquorio & 10 & 322,21 & 63,76 \\
Direlto & 10 & 263,62 & 85,38 \\
\hline
\end{tabular}


TABELA III - Valores da Área, apresentados pelo grupo imobilizado.

\begin{tabular}{|c|c|c|}
\hline \multicolumn{3}{|c|}{ Área (g.mm) } \\
\hline Anina: & 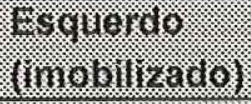 & Trimilor: \\
\hline 1 & 266,41 & 275,64 \\
\hline 3 & 371,8 & 276,73 \\
\hline 4 & 187,01 & 173,015 \\
\hline 5 & 458,99 & 329,39 \\
\hline 6 & 331,84 & 264,32 \\
\hline 8 & 375,08 & 245,21 \\
\hline 9 & 363,04 & 347,22 \\
\hline 11 & 354,59 & 508,31 \\
\hline 12 & 335,64 & 368,42 \\
\hline 13 & 423,69 & 357,78 \\
\hline 15 & 217,51 & 359,42 \\
\hline 17 & 569,78 & 367,68 \\
\hline 19 & 522,05 & 372,79 \\
\hline 21 & 137,93 & 359,78 \\
\hline 22 & 502,34 & 307,74 \\
\hline 23 & 301,73 & 271,29 \\
\hline 24 & 476,38 & 486,26 \\
\hline 25 & 376,93 & 375,8 \\
\hline 26 & 372,86 & 321,31 \\
\hline 27 & 524,25 & 624,18 \\
\hline 29 & 333,66 & 315,92 \\
\hline 32 & 414,13 & 307,87 \\
\hline 37 & 299,42 & 277,48 \\
\hline 38 & 270,03 & 603,82 \\
\hline 40 & 292,1 & 358,86 \\
\hline
\end{tabular}

Foram então, obtidos os seguintes valores para a Média e Desvio Padrão, em relação à Área, para o grupo imobilizado.(TABELA IV)

Tabela IV - Valores da média e do desvio padrão da área para o grupo imobilizado

\begin{tabular}{|c|c|c|c|}
\hline & $n$ & Merara & 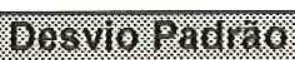 \\
\hline 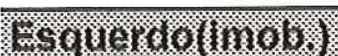 & 25 & 363,16 & 105,56 \\
\hline 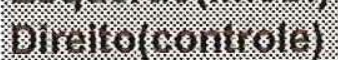 & 25 & 354,25 & 102,54 \\
\hline
\end{tabular}

